\title{
GENERATING CHANGE: \\ SUSTAINABLE ADAPTIVE REUSE OF URBAN POWER PLANTS \\ IN-DEPTH CASE STUDIES AND PLANNING IMPLICATIONS FOR THE HEARN, TORONTO
}

by

\author{
Julia Smith \\ MA, Maastricht University, 2011 \\ BA, University of Toronto, 2009 \\ A Major Research Paper \\ presented to Ryerson University \\ in partial fulfillment of the requirements for the degree of \\ Master of Planning \\ in \\ Urban Development
}

Toronto, Ontario, Canada, 2015

(C) Julia Smith 2015 


\section{Author's Declaration for Electronic Submission of a MRP}

I hereby declare that I am the sole author of this MRP. This is a true copy of the MRP, including any required final revisions.

I authorize Ryerson University to lend this MRP to other institutions or individuals for the purposes of scholarly research.

I further authorize Ryerson University to reproduce this MRP by photocopying or by other means, in total or in part, at the request of other institutions or individuals for the purpose of scholarly research.

I understand that my MRP may be made electronically available to the public. 


\title{
GENERATING CHANGE: \\ SUSTAINABLE ADAPTIVE REUSE OF URBAN POWER PLANTS IN-DEPTH CASE STUDIES AND PLANNING IMPLICATIONS FOR THE HEARN, TORONTO
}

(C) Julia Smith 2015

Master of Planning

in

Urban Development

Ryerson University

\begin{abstract}
Cities across the western world are making the transition away from coal energy, and towards greener methods of power generation; as a result, abandoned power plants, including Toronto's Richard L. Hearn Power Generation Station, are now features of many post-industrial urban landscapes. Largely out of use since 1983, the Hearn has seen a variety of redevelopment concepts over the last 30 years, but recent initiatives to revitalize Toronto's Waterfront and industrial Port Lands have spurred renewed interest in the site. In order to provide direction for the Hearn's impending redevelopment, indepth case studies of two adaptively-reused urban power plants, London's Battersea Station and Austin's Seaholm Plant, were performed via document analysis and key informant interviews. Salient themes, issues, and commonalities shared by all three cases were identified and explored, and used to formulate a series of seven development recommendations for the Hearn.
\end{abstract}

Key words: adaptive reuse; power plant; sustainability; brownfield; the Hearn; Battersea Station; Seaholm Power Plant 


\section{Acknowledgements}

First and foremost, thanks are due to my faculty supervisor, Dr. Christopher De Sousa, who provided his research framework, expertise, and guidance for this MRP; your deep knowledge, encouragement and candour over the course of this project have been invaluable. Thanks also to Michael Kraljevic at the Toronto Port Lands Company (TPLC), who served as a second reader for this MRP, to Tina Panagoulia (also at TPLC) who similarly provided astute feedback on my research, and to Rebecca Ramsey, who readily shared her knowledge with me, and excited me about delving deeply into this topic. I would also like to acknowledge the valuable contributions made by all key informants interviewed for this project. Your insight informed and shaped this report, and your willingness to share your thoughts and experiences was inspiring. Lastly, to my incredibly loving and unfalteringly supportive friends, family, and husband: thanks for everything. It takes a village.

With that said, all errors are the author's alone. 


\section{Dedication}

To Pawan. May we always look back on this first summer with joy. 


\section{Table of Contents}

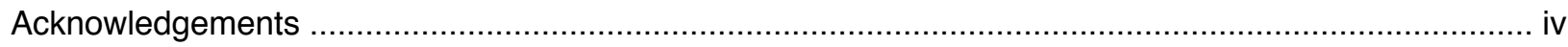

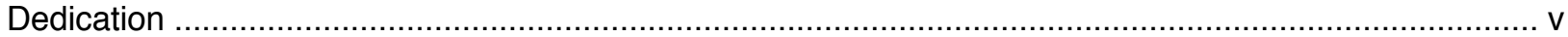

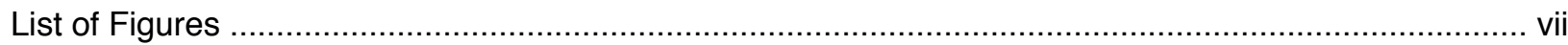

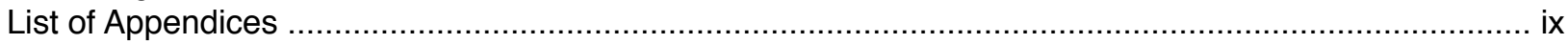

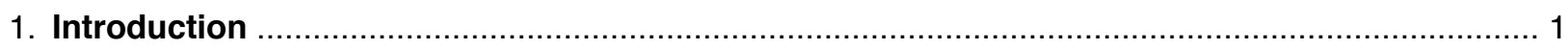

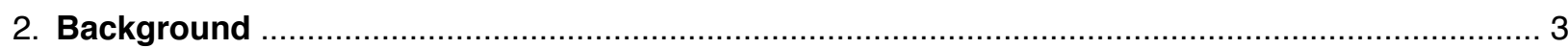

2.1 Sustainable Brownfield Redevelopment: Literature Review ............................................ 3

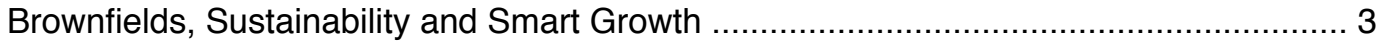

The Benefits of Brownfield Redevelopment .............................................................. 4

Factors Influencing Brownfield Project Success ...................................................... 5

2.2 The Richard L. Hearn Power Generation Station, Toronto, ON …................................... 9

Site Description and Context ............................................................................ 9

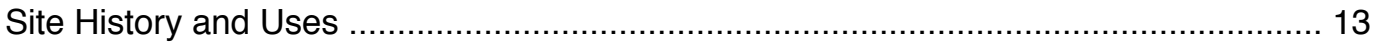

Planning History and Current Planning Context ...................................................... 15

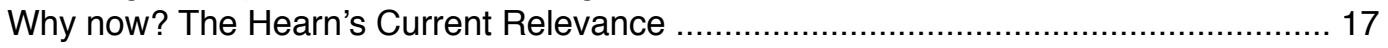

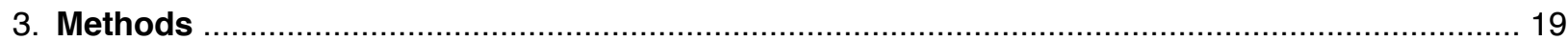

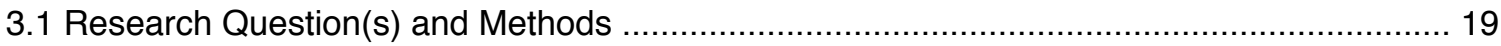

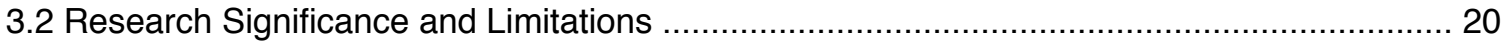

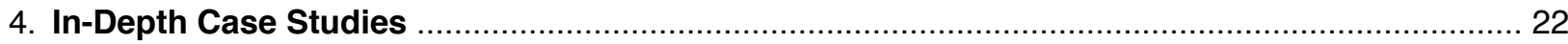

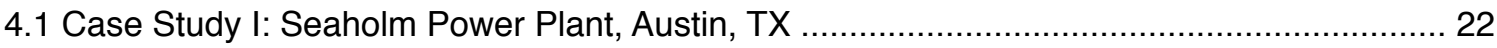

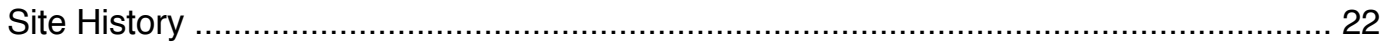

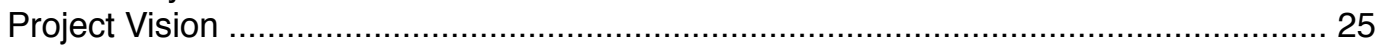

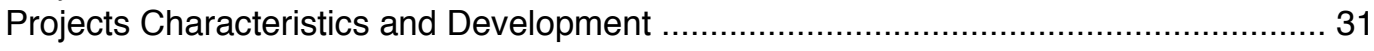

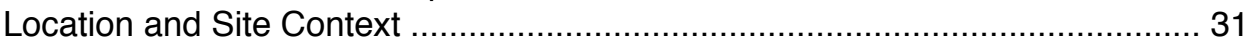

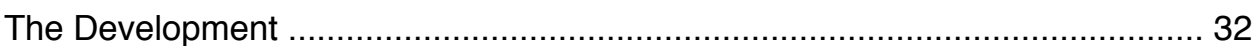

Sustainability Features ...................................................................... 35

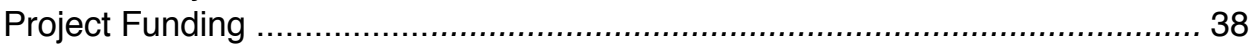

Lessons Learned: Project Enablers and Barriers .................................................... 40

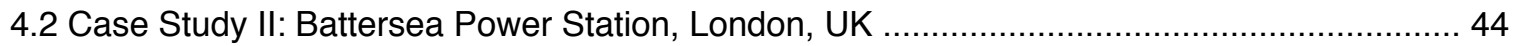

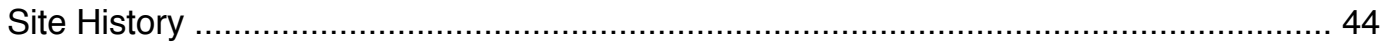

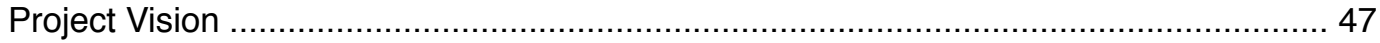

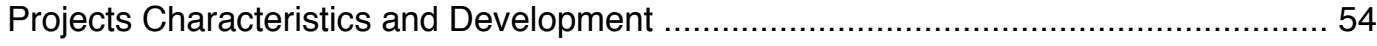

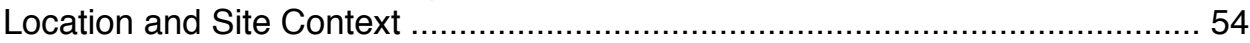

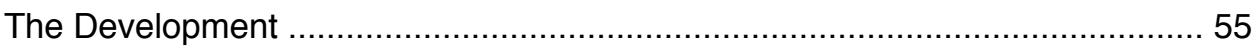

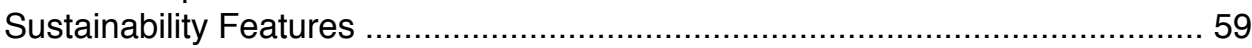

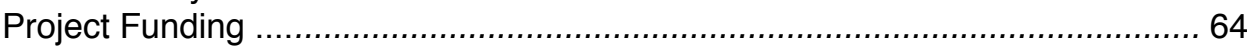

Lessons Learned: Project Enablers and Barriers ................................................. 65

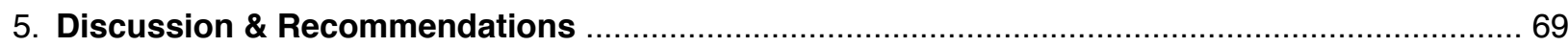

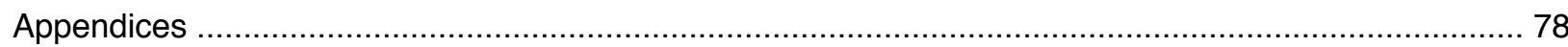

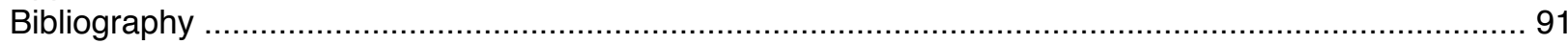




\section{List of Figures}

Figure 1. Aerial view of the Toronto Port Lands, with the Richard L. Hearn Power Generation Station in red (image source: City of Toronto, 2014, edited by author)

Figure 2. Aerial view of the Richard L. Hearn Power Generation Station, 2005 (image source: UrbanToronto, 2005) .10

Figure 3. Existing land uses in the Port Lands (image source: City of Toronto, 2014)........................12

Figure 4. The Hearn in the 1960s (image source: Axle/Urban Exploration Resource, 2009)...................14

Figure 5. The Hearn in the 1970s (image source: $x$ sicdn/Flickr, 1977) .............................................14

Figure 6. The Hearn's interior, before turbine removal (image source: Alex Luychx/Flickr, 2006)...... .14

Figure 7. The Hearn's interior, following turbine removal (image source: Andrew Williamson/BlogTO, 2015).

Figure 8. The Hearn during Luminato, 2014 (image source: Carlos Osorio/Toronto Star, 2014).....

Figure 9. The Hearn during the UnSound Music Festival, 2015 (image source: Jesse Milne/BlogTO, 2015).

Figure 10. Port Lands overall framework plan, showing the Hearn as an Opportunity Area (image source: City of Toronto, 2012).

Figure 11. Port Lands Planning Framework work program (image source: City of Toronto, 2014)...... 17

Figure 12. Austin Power Plant \#1, 1930s (image source: Austin History Center/Austin Public Library, 193?).

Figure 13. Advertisement for Burn \& McDonnell Engineering (image source: Austin History Center/Austin Public Library, 195?)

Figure 14. Construction on Austin Power Plan \#2 (image source: Austin History Center/Austin Public Library, 1951)

Figure 15. Austin Power Plant \#2 (later the Seaholm Plant) in the 1950s (image source: Austin History Center/Austin Public Library, 195?).

Figure 16. Interior of the Seaholm Plant, prior to turbine removal (image source: Austin History Center/

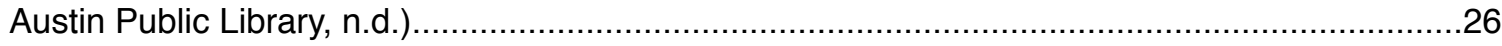

Figure 17. Interior of the Seaholm Plant, after turbine removal (image source: City of Austin, n.d.).........26

Figure 18. The Seaholm Master Plan, 2000 (image source: ROMA, 2000)......................................27

Figure 19. The Seaholm EcoDistrict (image source: Brendan Wittstruck/CMPBS, 2013).....................29

Figure 20. Seaholm EcoDistrict performance areas framework (image source: Brendan Wittstruck/ CMPBS, 2013). 
Figure 21. Seaholm Plant site context (image source: City of Austin, n.d.)......

Figure 22. Seaholm Plant south portal, east door (image source: Emily Meltzer, 2011)......................33

Figure 23. Seaholm Plant south portal, west door (image source: Emily Meltzer, 2011)........................33

Figure 24. Rendering of the new Seaholm development site (image source: SPLLC, n.d.)....................34

Figure 25. Interior of the redeveloped Seaholm Plant, as Athenahealth offices (image source: Nick Simonite/ Austin Business Journal, 2015).....

Figure 26. Rendering of Seaholm stacks interactive environmental media project (image source: Brendan

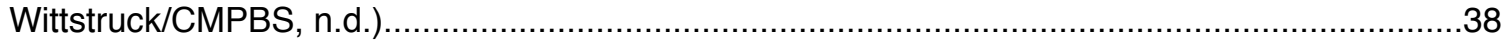

Figure 27. Battersea A, 1935 (image source: London Metropolitan Archives, 1935).............................45

Figure 28. Pick Floyd's 'Animals' album cover, 1977 (image source: Emily Koefoed, 2011)..................46

Figure 29. Booklet art for The Who's 'Quadrophenia' album, 1973 (image source: Emily Kofoed, 2011)..46

Figure 30. Battersea Station viewed from the south with west (left) wall and roof removed, 2008 (image

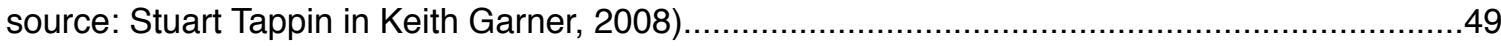

Figure 31. Battersea Station viewed from the south, 2008 (image source: Nigel Cox, 2008).................50

Figure 32. The VNEB Opportunity Area (outlined in red) in context, with Battersea Station shown in blue, and borough boundaries in yellow (image source: Greater London Authority, 2012, edited by author).

Figure 33. Fashion shoot in Battersea Station's control room (image source: Andrew Woffinden/BPSDC, 2014).

Figure 34. Light show at Battersea Station (image source: BPSDC, 2014)...... .53

Figure 35. Battersea Station in context, pre-redevelopment (with VNEB Opportunity Area outlined in red) (image source: Greater London Authority, 2012).

Figure 36. Illustration of the Battersea redevelopment, showing development phases (image source:

Peter Reynolds/BPSDC, 2014)

Figure 37. Rendering of Battersea Station's commercial interior, after redevelopment (image source: BPSDC, 2014).

Figure 38. Elevator in Battersea Station chimney (image source: BPSDC, 2014).

Figure 39. Proposed interior uses for Battersea Station after redevelopment (image source: BPSDC, 2014).

Figure 40. Rendering of the Battersea development (image source: BPSDC, 2014) .58

Figure 41. Battersea's landscape and transport connections to local area (image source: BPSDC, 2014). 


\section{List of Appendices}

Appendix A: Brownfields Sustainability BMP: Information Collection Table ................ 78

Appendix B: Ryerson Ethics Board Research Approval .........................................90 90 


\section{Introduction}

Cities across the western world are making the transition away from coal energy, and towards greener methods of power generation. Recent US public health legislation has spurred the closure of around 150 coal plants (Staple \& Slavin, 2012), while the last Canadian coal power station, the Thunder Bay Generating Station, burned its last piece of coal in 2014, and has since converted to advanced biomass fuel for energy production (Gross, 2014). While some coal plants such as the Thunder Bay facility have adopted new means of energy generation, the cost and inefficiency of such conversions has caused the complete decommissioning and abandonment of many former coal plants. Thus, in the wake of power generation innovation, abandoned former power plant brownfields litter many North American and European urban landscapes.

Unlike newer power plants, many coal power stations are located in key downtown areas, often occupy prime waterfront real estate, and have considerable heritage value (Raff et al., 2012). Thus, the adaptive reuse of such structures is often thought of as a more desirable alternative to continued abandonment or demolition (Staple \& Slavin, 2012). Such is the case with Toronto's Richard L. Hearn Generation Station (the Hearn). Largely out of use since 1983, the Hearn has seen a variety of redevelopment concepts over the last 25 years. However, with recent interest in the revitalization of Toronto's Waterfront, and particularly in the industrial Port Lands in which the Hearn sits, coming up with a new use for the massive former power station has become more pressing. Given the Hearn's location on a likely contaminated former industrial (brownfield) site, and complex planning, legal, heritage, environmental, infrastructural and ownership contexts, repurposing the site has proven challenging. Further, ensuring that any redevelopment of the Hearn is done sustainably adds another layer of complexity to the project.

However, many North American and European precedents exist for the sustainable adaptive reuse of urban coal power plants. Structures such as London, England's iconic Battersea Station, and Austin, Texas' Seaholm Power Plant are currently being 
sustainably redeveloped, and hence offer many parallels to the Hearn. These cases will be explored in depth through this research paper, to highlight salient themes and issues, and offer relevant lessons learned that could guide the Hearn towards reaching its immense potential. 


\section{Background}

\subsection{Sustainable Brownfield Redevelopment: Literature Review}

Brownfields, Sustainability and Smart Growth

Since the 1990s, there has been increasing interest in the remediation and redevelopment of brownfield sites throughout Europe and North America. The US Environmental Protection Agency (EPA) defines brownfields as "abandoned, idled, or under-used industrial and commercial facilities where expansion or redevelopment is complicated by real or perceived environmental contamination" (as cited in De Sousa, 2006, p. 393). Brownfields are typically located in post-industrial urban areas, and lie vacant as a result of the industrial exodus that has taken place in developed economies over the past half-century (De Sousa, 2000). However, given their central location, large footprint and general underutilization, these sites hold huge potential for economic, social, and environmental revitalization, and diverse stakeholders are interested in seeing them redeveloped into their highest and best use (De Sousa, 2006). To give a sense of the scale of the brownfields issue, it is estimated that $5-10 \%$ of urban land in the US is brownfield (Greenberg et al., 2001), with the total number of brownfield sites estimated at 450,000 (Howland, 2007). Similarly, in England, a majority of new residential development occurs on former industrial sites (Dixon, 2007). While the scope of the brownfields issue in Canada is less clear, it is estimated that as much as $25 \%$ of land in Canadian cities is contaminated from industrial use (De Sousa, 2006).

As brownfield remediation and redevelopment involves urban infill, and often results in environmental, social and economic benefits, the issue is intimately linked with both sustainability and smart growth. Sustainable development is typically based on a triplebottom-line approach, meaning that sustainable projects should maintain or improve economic, social, and environmental outcomes for future generations (Greenberg et al., 2001). Similarly, smart growth, which entered the planning lexicon in the early 90s (Ye, Mandpe \& Meyer, 2005) advocates concentrating development to central places and 
along corridors by filling in vacant urban areas (Greenberg et al., 2001), hence reducing the negative consequences of sprawl (Ye, Mandpe \& Meyer, 2005). While definitions of smart growth vary across organizations, they converge in the importance they place on environmental, economic, and social outcomes (Ye, Mandpe \& Meyer, 2005). Further, all definitions stress planning for density, mixed uses and connectivity, public transportation, economic development, housing, community participation, and natural resource preservation (Ye, Mandpe \& Meyer, 2005). In their study on the efficacy of various smart growth policies, Greenberg et al. (2001) named brownfield redevelopment "the smartest smart growth policy in the US" (p. 140), as it has clear environmental, moral, and political advantages.

While brownfield redevelopment has been a focus of American and British policy makers, similar activity has stagnated in Canada (De Sousa, 2006). The UK government in particular has leveraged their sustainability focus to instill a strong sustainability agenda in all brownfield remediation projects (Greenberg et al., 2001). Thus, while brownfield projects in the US and UK benefit from considerable public incentives, policies and support, similar projects are largely left to private market forces in Canada (De Sousa, 2006).

\section{The Benefits of Brownfield Redevelopment}

Given the focus on brownfield redevelopment in the US and UK, considerable research has explored the benefits of such projects. Consistent with sustainability and smart growth principles, the benefits of brownfield remediation generally include social, economic and environmental effects. De Sousa (2000) describes the benefits of brownfield redevelopment as including reduced greenfield development, increased public health, ecological preservation, renewal of urban cores, and an increased local tax base. Similarly, Greenberg et al. (2001) state that brownfield decontamination reduces health risks, and creates jobs, property taxes, housing and public amenities, often in underserved neighbourhoods. Further, comprehensive research on the effects of brownfield redevelopment presents empirical evidence of their benefits. In terms of 
environmental benefits, a study by Paull (2008) reports that 1 acre of brownfield development saves 4.5 acres of greenfield development. Further, a pilot study of 5 EPA Brownfield projects shows that brownfield development saves $32-57 \%$ of vehicle miles travelled compared with greenfield development, and reduces stormwater runoff by 47-62\% (EPA, 2015). The community benefits created by brownfield redevelopment include increased employment and property values. In fact, at the end of the 2014 fiscal year, the EPA Brownfields program alone had created 109,787 jobs and $\$ 23.3$ billion in investment (EPA, 2015). Further, remediation and redevelopment of brownfields has led to property value increases of $5.1-12.8 \%$ in nearby areas, while it is estimated that \$17.54 was leveraged on each EPA Brownfields dollar, and 8.2 jobs created for every $\$ 100,000$ spent on the program (EPA, 2015). Pall's 2008 study also underscore that brownfield redevelopments often lead to increased local tax base and lower infrastructure costs. A survey of 62 US cities indicated that brownfield redevelopment led to a $\$ 408$ million increase in annual local taxes (Paull, 2008), while redeveloping their remaining former-industrial sites could mean up to $\$ 3.8$ billion in additional local taxes (Paull, 2008). Further, infrastructure is much more economical to provide in compact urban areas, and every dollar spent on infrastructure in redeveloped brownfields translates to $\$ 10$ in greenfield developments (Paull, 2008).

\section{Factors Influencing Brownfield Project Success}

Despite the many benefits of brownfield redevelopment listed above, defining success in brownfield projects is often complicated and subjective. This is due to the diverging values and expectations of the many stakeholders involved in brownfield projects (Lange \& McNeil, 2004). For example, in a study of 228 brownfield pilot programs, Lange and McNeil (2004) found that public officials and community groups often see environmental improvements as an important indicator of success, while developers are more likely to prioritize financial returns over environmental benefits. However, there does seem to be a general trend towards using economic indicators as benchmarks for

project success (Howland, 2007). Despite these understandable differences in measuring success, Lange and McNeil's (2004) study found that the two most common 
indicators of brownfield project success were the creation of long-term jobs and increased local tax base, while environmental improvements ranked 7th. Further, another study involving interviews with private and public stakeholders indicated that increasing property taxes was more important than reducing environmental contamination (De Sousa, 2005). Given the market-driven nature of property development, it is unsurprising that economic outcomes often trump social and environmental factors (Dixon, 2007).

Despite the nebulous concept of success in most brownfield projects, there has been considerable scholarly attention paid to factors that either serve as facilitators or barriers to brownfield redevelopment. The factors influencing project outcomes and success include financial viability, liability, timelines, infrastructure and accessibility, project size and image, and political and community support. Financial viability is perhaps the mostcited factor influencing the outcome of brownfield projects. As brownfield redevelopment is considerably more expensive than greenfield development, developers must see the potential for adequate returns in order to undertake a brownfield project (Alberini et al., 2005). Financial feasibility of a project can be influenced by many factors including land values, market demand for central housing, government incentives and subsidies, and consulting fees (Nijkamp, Rodenburg, \& Wagtendonk, 2002). De Sousa (2000) found that residential developments in high-demand areas are often the most financially successful, as these projects provide sufficient returns to overcome the risks and costs of environmental remediation. Similarly Lange \& McNeil (2004) isolate the availability of incentives as an important success factor to brownfield projects. The same study also identifies liability as a significant obstacle, as many developers are unclear about their responsibility regarding contaminated sites. De Sousa's (2000) study found that protection from liability, as well as access to tax incentives and financial mechanisms such as Tax Increment Financing (TIF) have the most effect on project feasibility. The longer timelines of brownfield projects are also a factor that can influence project success, mainly because they lead to higher financing costs and delayed revenues (De Sousa, 2000; Wernstedt et al., 2006). A survey conducted by Lange \& McNeil (2004), also highlights the importance of time, as the median development time for successful 
brownfield projects was 12 months, while unsuccessful sites had an average timeline of 36 months. As brownfield projects are viewed as financially risky, any scheme that reduces or shares risk, such as Public Private Partnerships (P3s), or joint ventures, can have positive effects on project outcomes (Dixon, 2007).

Lange and McNeil's (2004) study also underscores the importance of infrastructure and connectivity in brownfield redevelopment. While $54.2 \%$ of successful sites benefitted from existing infrastructure, that figure fell to $28.6 \%$ of unsuccessful projects; transportation access was also deemed critically important to brownfield project success (Lange \& McNeil, 2004). Lange and McNeil (2004) also highlight that effective brownfield revitalization projects are usually well-integrated into surrounding neighbourhoods. Similarly, brownfield redevelopments that have positive impacts on existing businesses in the area have also been more successful (Lange \& McNeil, 2004). De Sousa (2006) also stresses the importance of integrating brownfield projects into surrounding neighbourhoods, as well as the creation of social infrastructure to serve the new residents of revitalized brownfield sites. Similarly, UK studies by Dixon (2006; 2007) reveal that infrastructure and connectivity are major determiners of brownfield success, with public transportation, connections to surrounding neighbourhoods, pedestrian bridges, and social infrastructure like schools and hospitals recognized as vitally important. This was also reiterated by Farris (2001), who isolates access to transit and proximity to employment centres as key influencers of brownfield infill effectiveness.

Project scale has also been shown to affect brownfield redevelopment outcomes, and larger projects are generally more successful (Dixon, 2007). This may be due to the likelihood of larger projects also including public amenity and infrastructure improvements, the importance of which has been discussed above. Relatedly, Lange and McNeil (2004) argue that developments that include more green space are generally more successful. Project scale could also result in a stronger image or brand identity for the development, which has also been linked to project success. Successful brownfield redevelopments use branding to catalyse revitalization (Dixon, 2007), and many economists believe that revitalization projects must be large-scale in order to 
overcome negative externalities and spur revitalization (Farris, 2001). However, while such branding tends to lead to economic success, it is often at the expense of social benefit, and existing communities can be negatively impacted by gentrification, exclusion and displacement (Dixon, 2007).

Support from political leaders and community members has also been linked with brownfield project success. Politicians can not only help influence a project's outcome, but can also assist with overcoming bureaucratic hurdles (Lange \& McNeil, 2004). Further, in a study of UK developers, more than half of participants stated that early community engagement and consultation was important for project success (Dixon, 2006). However, both political support and community participation can be doubleedged swords. While political will may get a brownfield redevelopment project off the ground, the desire to take action during the current political term may drive politicians to push for premature development of brownfield sites. This could lead to project failure, as many sites require significant time to accumulate land value and demand in order to be feasible (Farris, 2001). In terms of community engagement, neighbourhood opposition can also be a barrier to successful brownfield redevelopment (De Sousa, 2006). Further, the need to engage in community dialogue in central urban areas has also been cited as a deterrent to infill development, as many developers prefer to build in greenfield areas lacking stringent community consultation guidelines (Farris, 2001).

Despite the environmental remediation at the core of brownfield projects, several studies underscore the fact that remediation of contaminants is not widely regarded as critical to project success (Lange \& McNeil; Dixon, 2007).

Interestingly, many of the benefits, barriers and enablers of brownfield redevelopment isolated in this literature review were echoed during investigation of the Seaholm and Battersea power station redevelopment projects, and are thus likely to also be of relevance to the Hearn's impending transformation. These commonalities will be discussed in more detail later in this report, and recommendations for the Hearn will largely be based on these parallel qualities and features. 


\subsection{The Richard L. Hearn Power Generation Station, Toronto, ON}

As the overall aim of this research project is to provide planning direction for the Richard L. Hearn Power Generation Station through the exploration and analysis of urban power plant redevelopment precedents, a description of the Hearn, along with its site, history, planning context and current relevance is warranted. This detailed explication will isolate the Hearn's salient features, challenges and opportunities, and will allow important comparisons and contrasts to be made with the two international case study sites, Austin's Seaholm Power Plant, and London's Battersea Station.

\section{Site Description and Context}

Located at 440 Unwin Ave. in the Toronto Port Lands, on the eastern edge of Toronto's central waterfront and south of the Shipping Channel, the Richard L. Hearn Power Generation Station (the Hearn) is a monument to Toronto's rich industrial past. Recently, growing interest in the Port Lands from the City, politicians, developers, and community members has highlighted the Hearn's unique and valuable waterfront location,

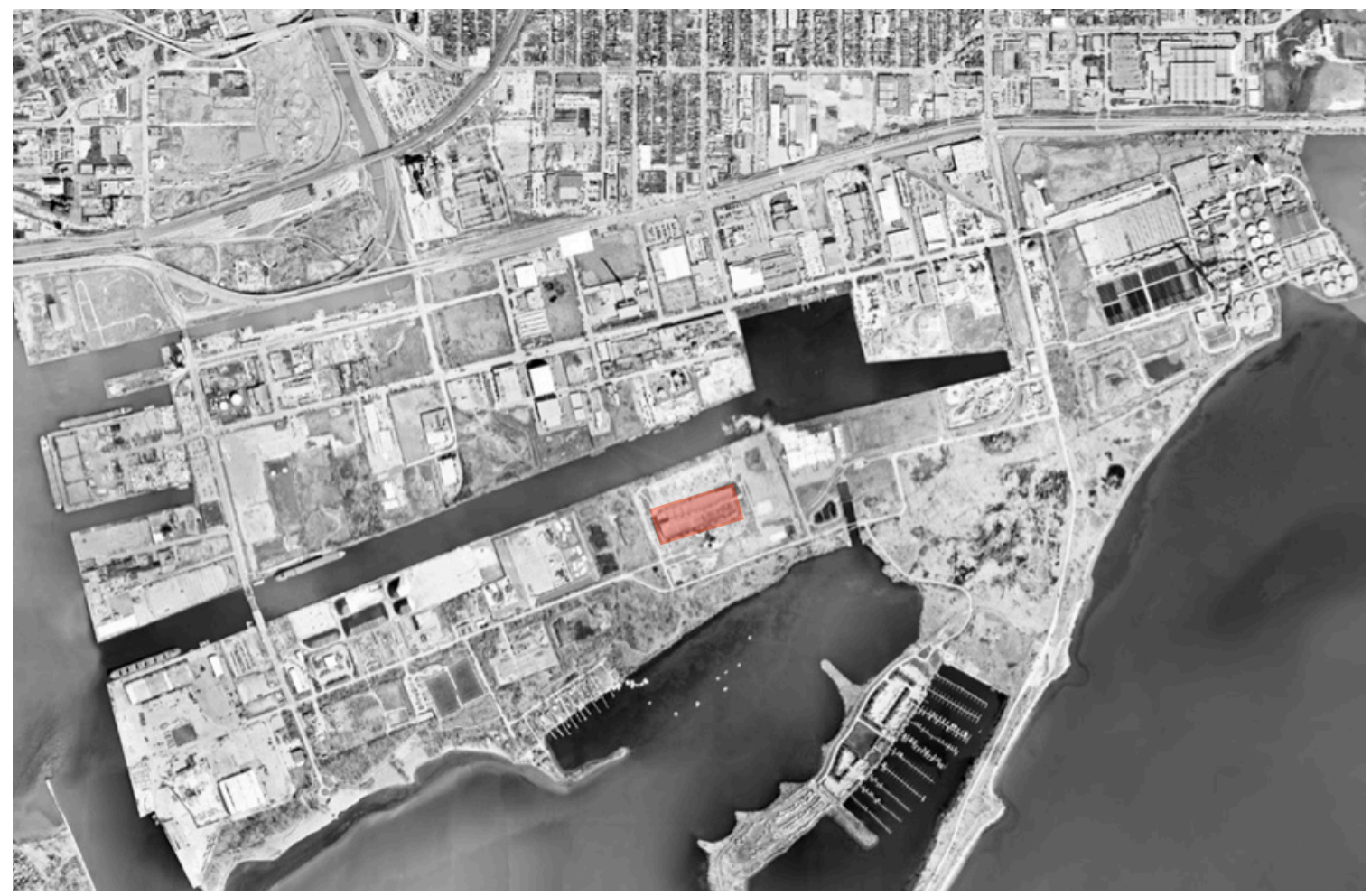

Figure 1. Aerial view of the Toronto Port Lands, with the Richard L. Hearn Power Generation Station in red (image source: City of Toronto, 2014, edited by author) 
architectural merit, historic significance, and potential to become a catalytic site for the revitalization of both the Port Lands and Toronto's Waterfront more broadly. As such, diverse visions for the Hearn's redevelopment have been put forward by various stakeholders over the past decade, including a sports complex, a university campus, a creative industries hub, and even a cemetery.

Built in 1952, the Hearn consists of structural steel framework, red brick infill walls, and a reinforced concrete slab floor (Martin, 2014). The Hearn's concrete foundation is one of the site's greatest attributes and makes it ideal for redevelopment (Lu, 2014); built to support heavy boilers and turbines running 24 hours a day (Weins, 2014) the building rises from a 12-foot-deep cement foundation with 100-foot pilings extending into bedrock (Ramsey, 2015). The Hearn consists of two parallel primary spaces: the boiler room on the south side of the building, and the turbine room in the north (Martin, 2014). With a footprint of $24,000 \mathrm{~m} 2$, an existing floor area of $33,000 \mathrm{~m} 2$, and a height $41.5 \mathrm{~m}$, the Hearn features a cavernous 650,000 cubic metre interior space almost as large as the Rogers Centre (Ramsey, 2015). Further, the Hearn's soaring 750 foot chimney,

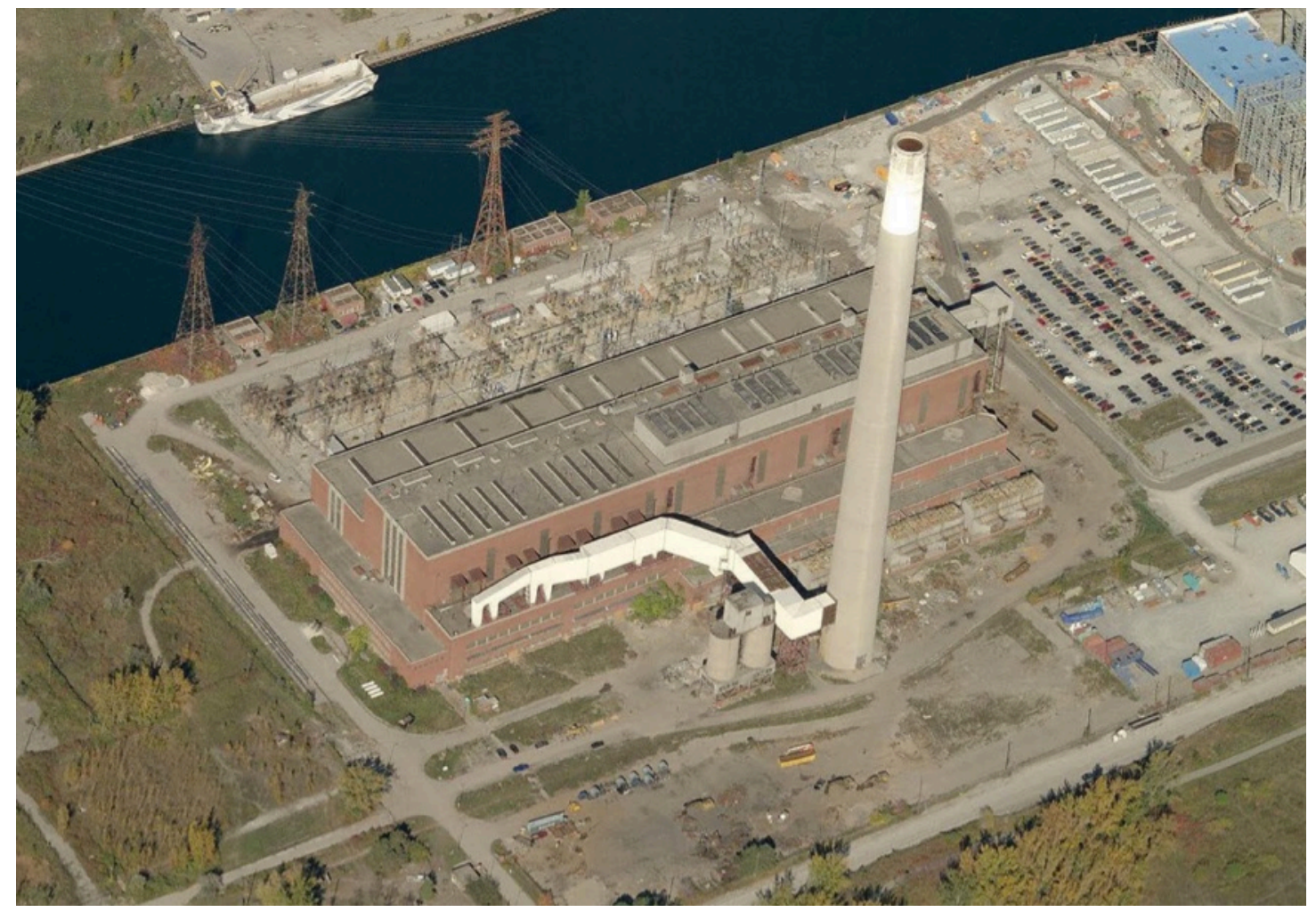

Figure 2. Aerial view of the Richard L. Hearn Power Generation Station, 2005 (image source: UrbanToronto, 2005) 
which forces eastbound planes to takeoff steeply from the Toronto Island Airport (Wiens, 2014), is a prominent and iconic figure on the Toronto skyline.

Originally decommissioned in 1983 (Ramsey, 2015), the Hearn is currently owned by the Province of Ontario through its crown corporation, Ontario Power Generation (Kuitenbrouwer, 2010). However, the site is under long-term lease to a private development company, operating under the name Studios of America (SoA) (Kuitenbrouwer, 2010). While reports of the lease term vary, most sources agree that SoA can extend their lease over the site until at least 2041 (Lu, 2014). The Hearn's lease agreement also allows SoA to alter and even demolish parts of the site (Lu, 2014). Consequently, when SoA first acquired the site in 2002, they emptied the Hearn's main turbine hall of its historic power generation turbines and melted them down for metal (Weins, 2014). However, the 8 massive concrete plinths used to support the turbines remain, giving the Hearn's interior a vaulted industrial presence (Martin, 2014). The Hearn's vintage control room, however, has remained largely intact, as is used as a set for many of SoA's productions. While not officially designated, the Hearn was listed as a City of Toronto heritage building in $2003^{1}$, meaning that its owners must give the City at least 60 days notice before removing of demolishing the building. Despite its heritage value, after nearly 30 years of neglect, the Hearn is showing signs of disrepair (Wiens, 2014).

Given its location in Toronto's Port Lands, the Hearn is surrounded by active industrial properties, and has a complex planning context; it is bounded on the north by the Shipping Channel wall, on the west by the Canada Salt Terminal, and to the east by the Portlands Energy Centre and LaFarge Canada Cement Terminal (Ramsey, 2015). Immediately across the Shipping Channel lies the privately-owned Pinewood Studio, a huge film production site opened in 2008 (Martin, 2014). The area surrounding Pinewood is also presided over by the City's Film Studio District Precinct Plan (City of Toronto, 2014). There are also several recent residential and commercial development

\footnotetext{
1 While the Hearn is listed as a heritage building by the City of Toronto, it has never been designated, as the City cannot designate provincially-owned buildings.
} 


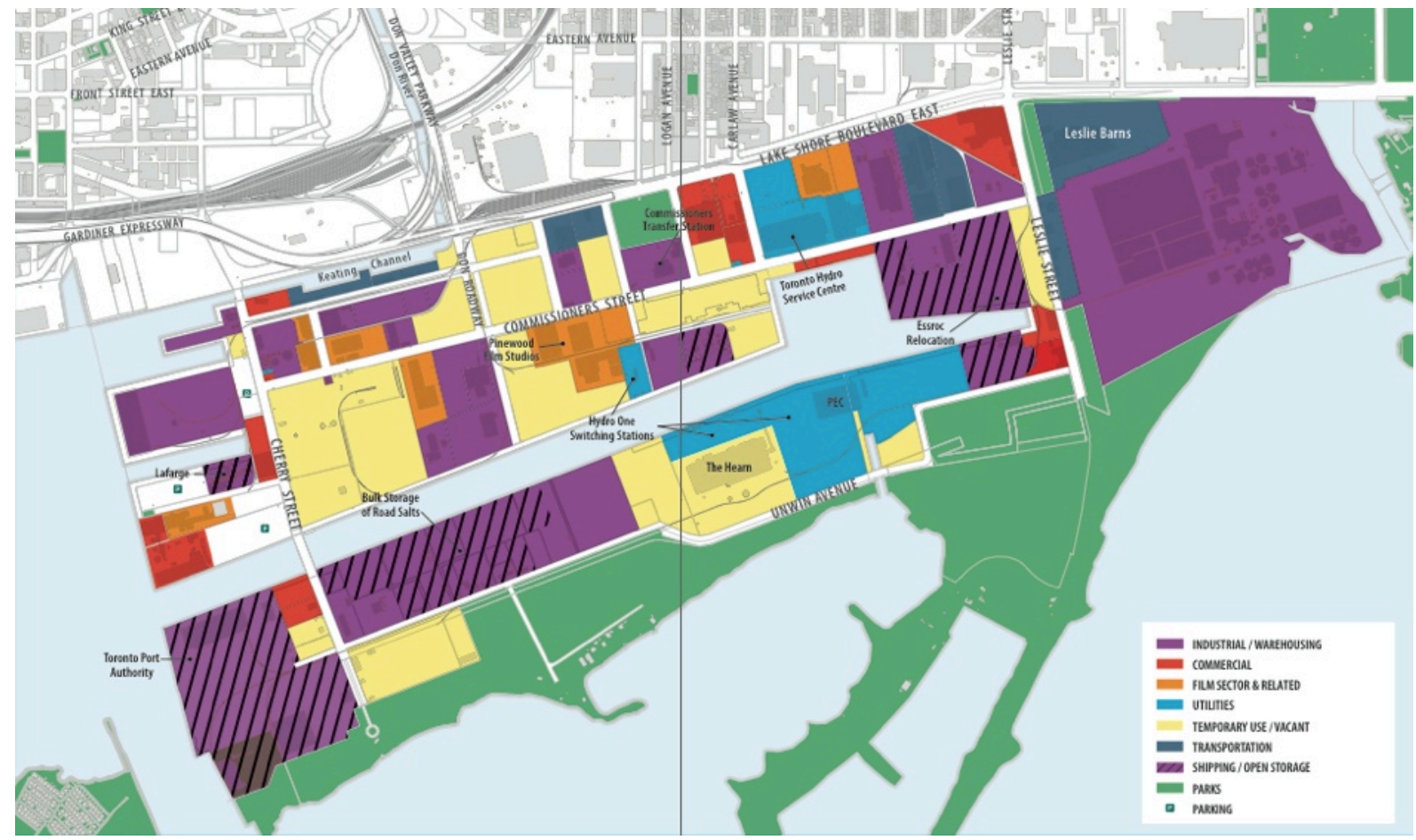

Figure 3. Existing land uses in the Port Lands (image source: City of Toronto, 2014)

projects taking place around the Port Lands, including the West Don Lands and the Unilever Lands projects, as well as major infrastructure and environmental projects including the Gardiner Expressway and the naturalization of the mouth of the Don River (City of Toronto, 2014). The Hearn's largely industrial surroundings also makes accessing the site challenging, as the area currently has limited road and transit access (Lu, 2013). This inaccessibility is exacerbated by several physical barriers, including the Shipping Channel to the north, and a rail spur just south of the site. The Hearn also lacks basic infrastructure, and is unserved by water, sewage and electricity (Wiens, 2014). Further, development of the Hearn will have to navigate the complex web of ownership and jurisdiction that typifies Toronto's waterfront. For example, while the site itself is provincially owned and privately leased, it is surrounded by other private and public industrial lands, while the Shipping Channel immediately to its north is under Federal jurisdiction. With this said, the Hearn also benefits from several valuable assets. The Martin Goodman Trail, one of the City's largest cycling and pedestrian routes, runs along Unwin Ave., just south of the Hearn. Further, the Shipping Channel, while it separates the site from the rest of the city, also provides valuable waterfront access to 
shipping transport (City of Toronto, 2014), and protects the Hearn from flooding risk (Ramsey, 2015).

\section{Site History and Uses}

After several decades of serving as a filtration area for sewage transported via the Don River, the land around Ashbridges Bay on Toronto's waterfront became highly stigmatized (Martin, 2014). Looking for an appropriate use for such 'contaminated' real estate, the City decided to repurpose the area as an industrial zone, and plans for a deepwater port were drafted in 1883 (Martin, 2014). In 1912, the industrial vision for Toronto's waterfront expanded further, as an extensive waterfront plan was created that included reclaiming significant tracts of land for industrial purposes, including the port industrial district where the Hearn now sits (Martin, 2014). When ground broke on the Richard L. Hearn Power Generation Station in 1946, the Port Lands had already served as one of Toronto's most important industrial areas for several decades.

Completed in 1952, The Hearn was named after Dr. Richard Lankaster Hearn, chief engineer, chairman and manager of the Ontario Hydro Commission between 1945 and 1956 (Ramsey, 2015). The Hearn cost the province $\$ 156$ million to build, and while it was originally designed to hold two 100-megawatt steam-driven turbines, two additional units were installed in the station during the 1950s (Ramsey, 2015). In order to serve Toronto's burgeoning postwar population and its increasing reliance on electrical appliances, four more turbines were added to the Hearn in 1960; all 8 turbines were coal-powered (Ramsey, 2015). By 1961, the Hearn's energy output had increased enormously, and the station was consuming 3 million tons of coal annually (Martin, 2014). At this point it was Canada's largest coal station, standing at 14-storeys tall and employing 300 people (Ramsey, 2015). However, the station continued to evolve. In the 1970s, several small chimneys were replaced with the giant smokestack that now towers over Toronto's waterfront (Martin, 2014). This taller chimney, which cost $\$ 9$ million to construct (Ramsey, 2015), is located south of the plant, and was necessary to reduce the amount of noxious sulphur dioxide released over the city as a result of the 


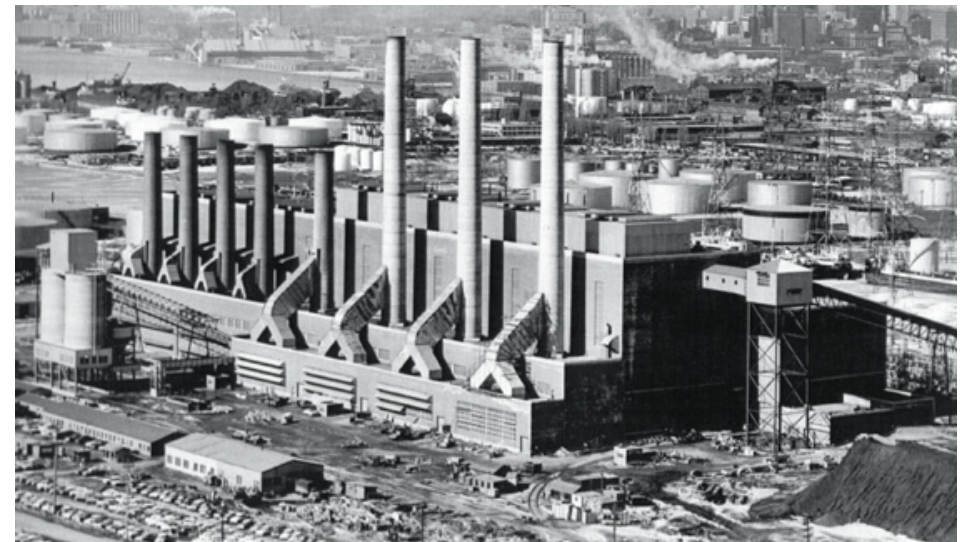

Figure 4. The Hearn in the 1960s (image source: Axle/Urban

Exploration Resource, 2009)

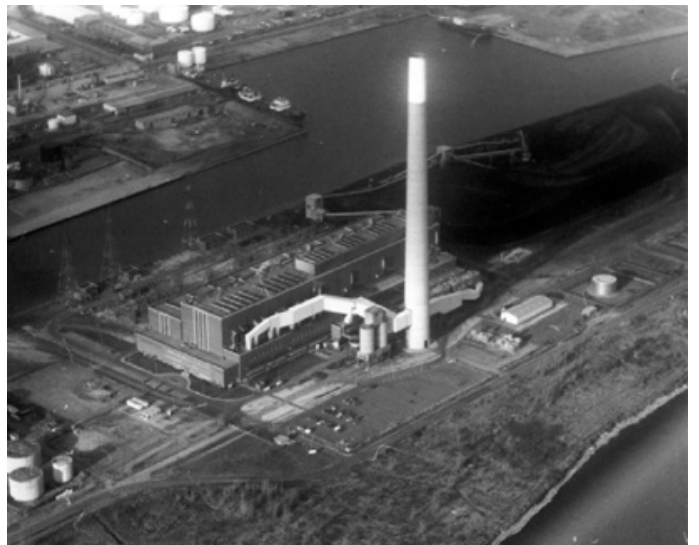

Figure 5. The Hearn in the 1970s (image source: xsicdn/ Flickr, 1977)

coal power generation process (Martin, 2014). Also in the 1970s, 4 of the Hearn's original coal-fired turbines were converted to burn natural gas (Ramsey, 2015). The 70s also saw significant changes to the area surrounding the Hearn, and by 1974 , the land used for industrial purposes in the Port Industrial District had decreased by nearly $80 \%$ (Martin, 2014).

By the 1980s, the energy production technology used by the Hearn was no longer economically feasible, and the station ceased power generation in 1983 (Ramsey, 2015). However, the structure did continue to have marginal use by Ontario Hydro as a voltage regulator until 1995 (Ramsey, 2015). Since its decommission, Ontario Power Generation has explored several opportunities to reuse the site, including a 2001 plan to adaptively reuse the Hearn as a new power plant (Ramsey, 2015). Due to cost ineffectiveness, this plan was never realized, and in 2002 the site was leased to SoA.

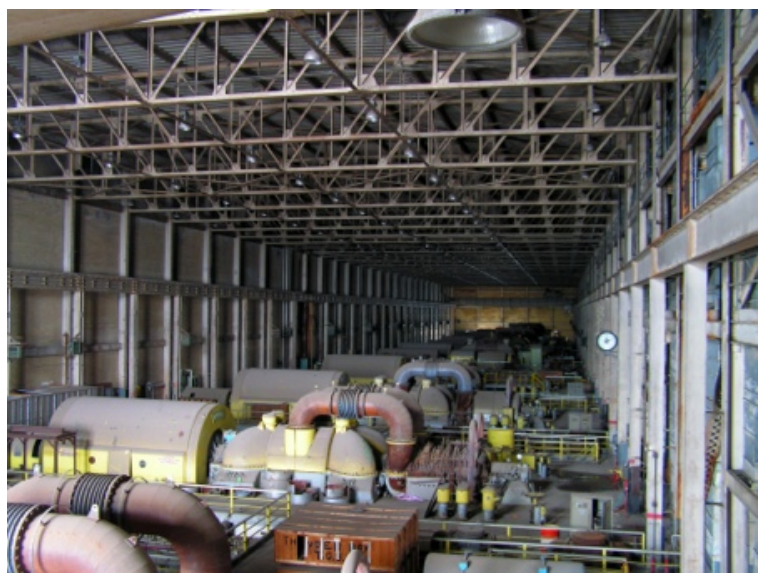

Figure 6. The Hearn's interior, before turbine removal (image source: Alex Luychx/Flickr, 2006)

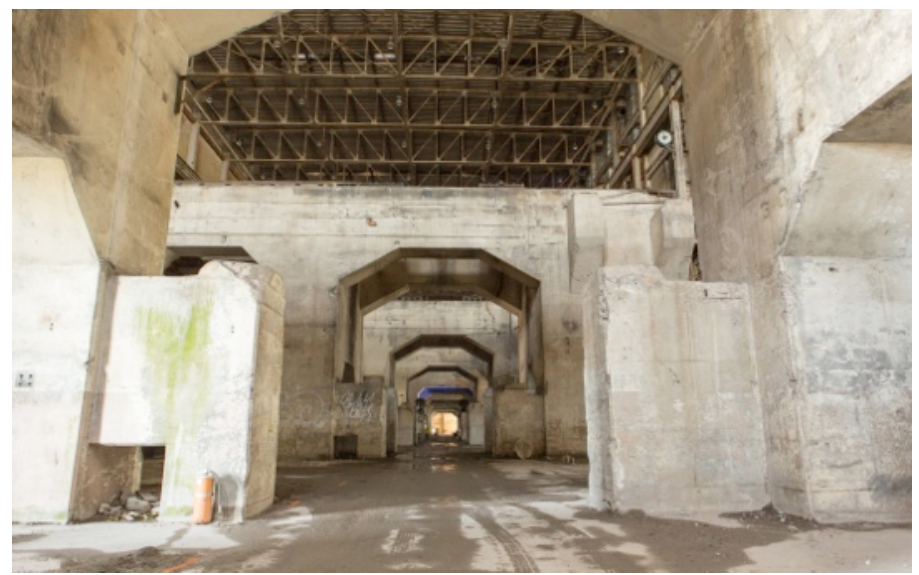

Figure 7. The Hearn's interior, following turbine removal (image source: Andrew Williamson/BlogTO, 2015) 


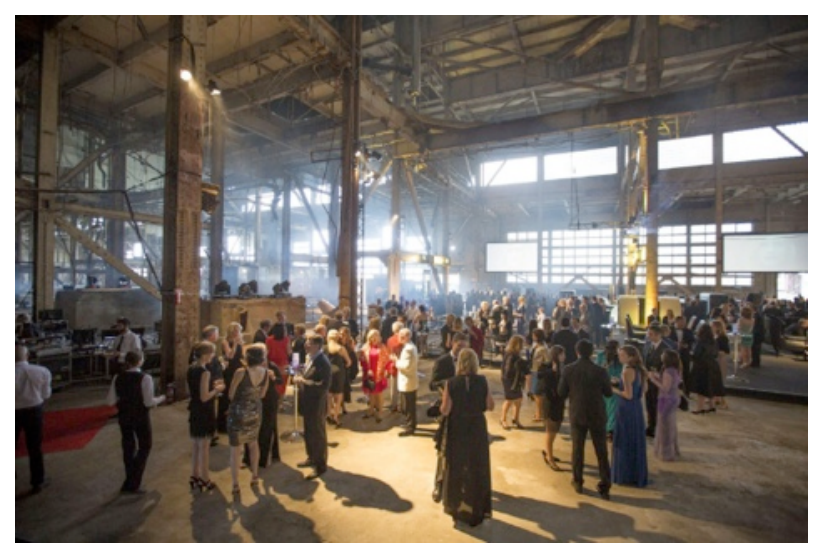

Figure 8. The Hearn during Luminato, 2014 (image source: Carlos Osorio/Toronto Star, 2014)

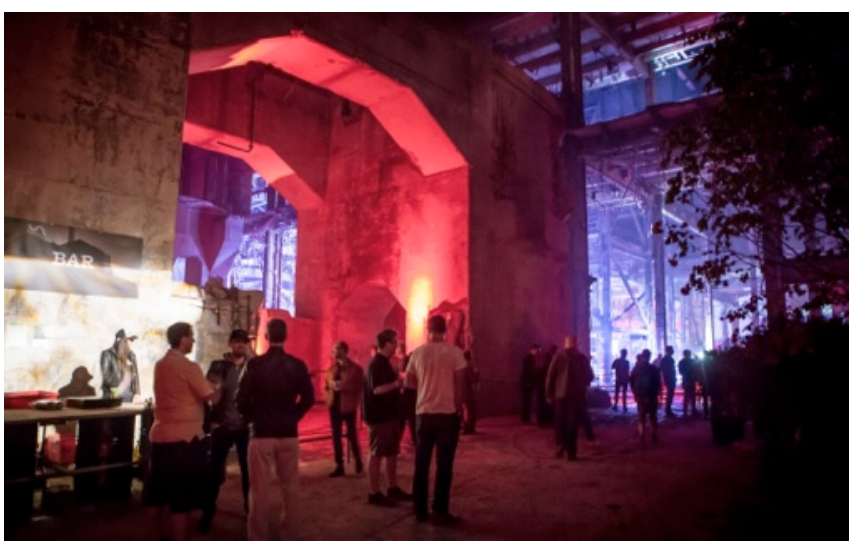

Figure 9. The Hearn during the UnSound Music Festival, 2015 (image source: Jesse Milne/BlogTO, 2015)

As previously mentioned, SoA has made significant changes to the Hearn's interior, including clearing out all original turbines, leaving the building's cavernous interior largely unobstructed. However, SoA does not frequently use the Hearn for film shoots, and it remains vacant most of the year. Due to its large interior and gritty industrial aesthetic, the Hearn has been popular amongst urban explorers since its decommission. Further, the building has recently housed several cultural events, including a Vice Canada party and the Luminato Festival's opening gala in 2014, and most recently, Luminato's Unsound Music Festival in June 2015. Long established as an industrial, though inaccessible, presence on Toronto's waterfront, public interest in the Hearn is clearly burgeoning.

\section{Planning History and Current Planning Context}

As the Hearn sits within the Toronto Port Lands and is a prominent figure on the City's transforming waterfront, the power station has a complicated planning context which must be taken into account in any plans seeking to maximize this site's enormous potential.

Given the immense potential and largely underutilized nature of Toronto's Port Lands, they have been the focus of numerous studies, plans and policies in the city since the 1990s (City of Toronto, 2013). Most of these plans have isolated key challenges in the area, including isolation, lack of transportation, lack of communities, and lack of public 
spaces. In 1998, Unlocking the Toronto Port Lands: Directions for the Future was presented to Toronto City Council, and provided a "broad yet comprehensive vision" (City of Toronto, 2013, p. 50) for the area, focussing on green spaces, placemaking and transportation improvements. In 1999, interest in revitalizing Toronto's waterfront as a whole gained momentum, and the three levels of government united to create a report entitled Our Toronto Waterfront: Gateway to the New Canada, passed by Council in 2000 (City of Toronto, 2013). This report functioned as a strategic master plan for Toronto's waterfront, and presented a vision for the Port Lands rooted in open space, mixed uses and infrastructure upgrades (City of Toronto, 2013). In 2003, the Central Waterfront Secondary Plan (CWSP) was passed by City Council. This plan was based on the key principles of removing barriers and making connections, establishing a network of parks and public places, environmental protection, and creating dynamic and diverse new communities (City of Toronto, 2013). The CWSP also specifically identifies the Hearn site as a regeneration area (City of Toronto, 2014).

From 2003-2011, several development schemes were explored for the Hearn site and surrounding properties. However, none of these took off due to budgetary and feasibility

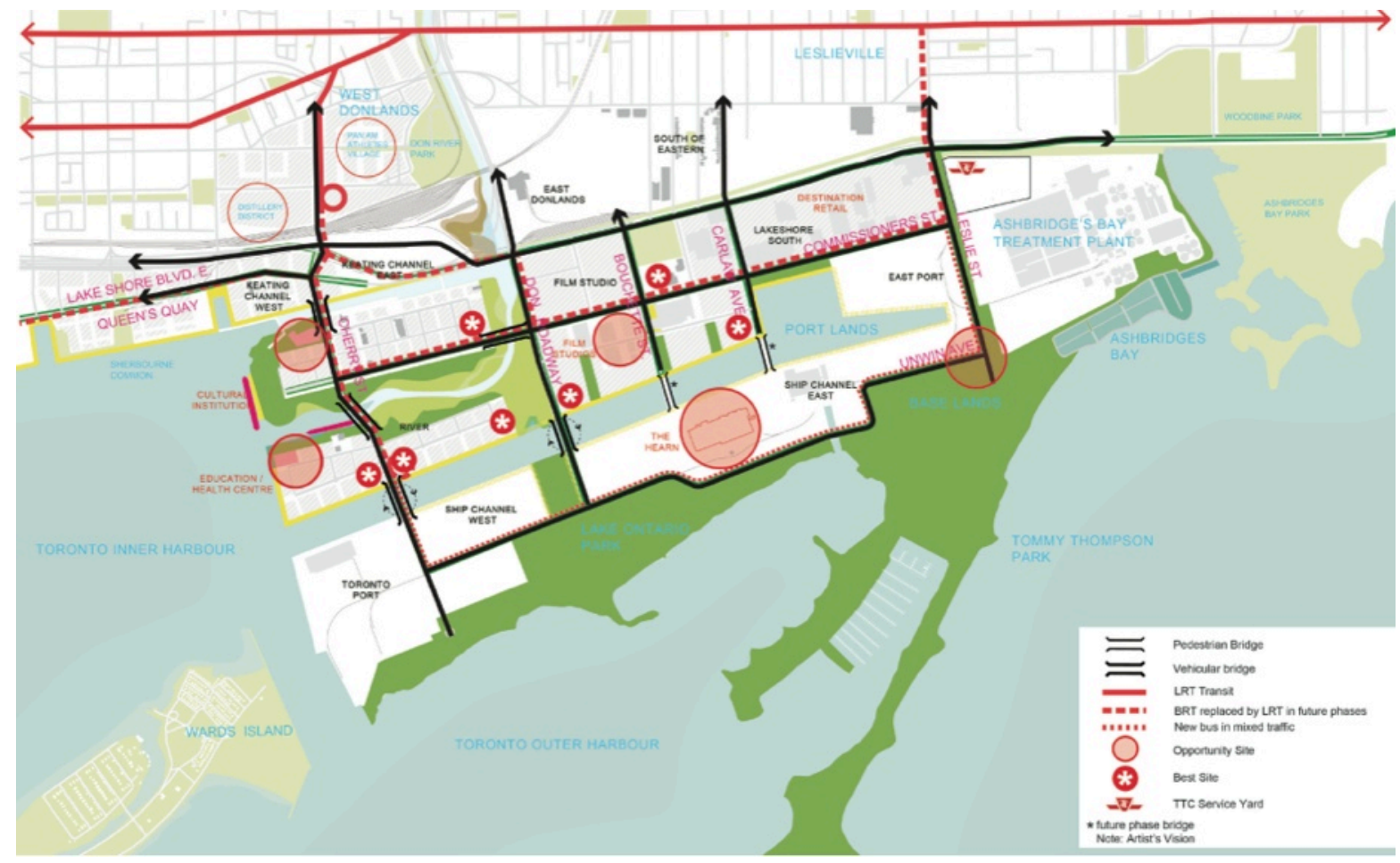

Figure 10. Port Lands overall framework plan, showing the Hearn as an Opportunity Area (image source: City of Toronto, 2012) 


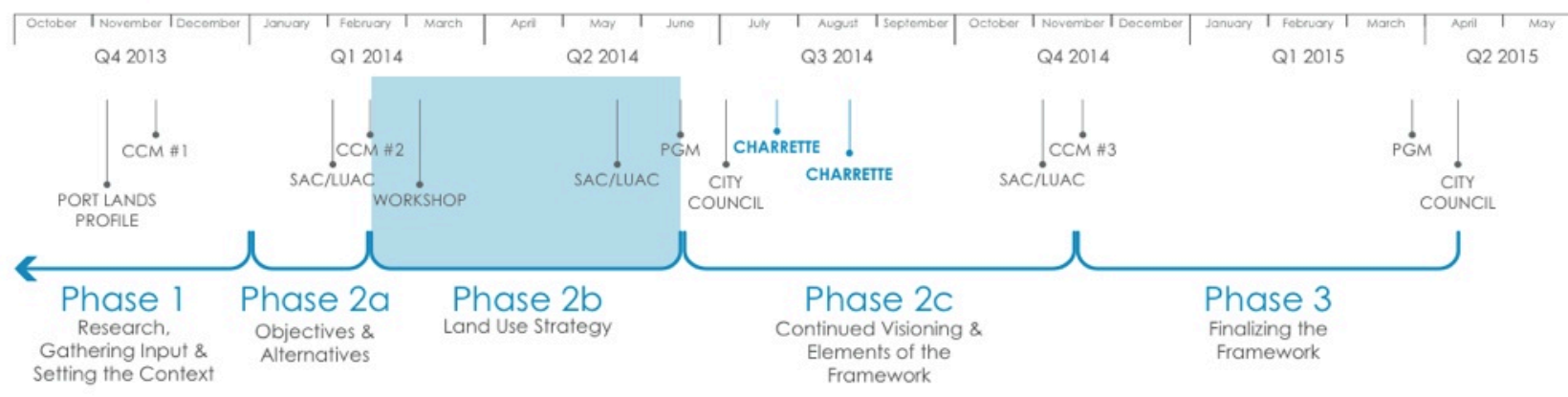

Figure 11. Port Lands Planning Framework work program (image source: City of Toronto, 2014)

challenges (Ramsey, 2015). In 2011, after several years of stagnation in the Port Lands, the Port Lands Acceleration Initiative (PLAl) was created in order to accelerate development in the area (City of Toronto, 2013). The PLAI suggested investing in flood protection and infrastructure to spur private development in the area, and was endorsed by City Council in 2012 (City of Toronto, 2013). As with many previous plans for the area, the PLAl focusses on transit improvements, the creation of parks and green spaces, and improving overall connectivity with the city (City of Toronto, 2013). The plan also highlights the importance of identifying catalyst sites that will help the area become a centre for creativity and innovation, as mandated by the earlier CWSP (City of Toronto, 2013).

In 2013, work started on the Port Lands Planning Framework (PLPF). Phase I of the Framework consisted of conducting extensive background research on the area, and resulted in the Port Lands Profile (City of Toronto, 2013); Phase II involved creating a land use strategy for the area, and continued visioning. The Port Lands Planning Framework: Land Use Direction (City of Toronto, 2014) identifies the Hearn as one of the area's major assets, and labels it one of 5 opportunity sites in the Port Lands. Although the PLPF was projected to go to City Council for approval in April, 2015, the framework has yet to be completed.

\section{Why now? The Hearn's Current Relevance}

As mentioned, recent interest in the Hearn has been growing. While the Hearn has lain underutilized on Toronto's waterfront since it was decommissioned in 1983, several 
high-profile stakeholders have brought the building to light. Besides housing several large cultural events in 2014 and 2015, Mike Williams, the City of Toronto's general manager of economic development, has labelled the Hearn "one of the most phenomenal opportunities" for redevelopment Toronto ( $\mathrm{Lu}, 2014)$. While adaptive reusing the massive structure has often been regarded as unfeasible due the prohibitive costs associated with projects of this scale, growing real estate value in Toronto, especially along the waterfront, will likely make this project viable in the near future. However, there are several key challenges with the site that will have to be surmounted in order for a successful outcome. Besides the aforementioned costs of a such a project, the site also features unclear ownership terms, a difficult active industrial context, a need for brownfield remediation, notable disconnectedness from the rest of the city, lack of infrastructure and servicing such as water, sewage, electricity and public transportation, and heritage preservation concerns. Further, the Hearn has a group of supporters dedicated to seeing the project serve the local community as best as possible, including community groups, activists, and the Ward 20 Local Councillor Paula Fletcher.

As a judicious and evidence-based path forward for the Hearn is necessary, this research project will examine two comparable redevelopment projects. Through examining the redevelopment of the Seaholm Power Station in Austin, Texas, and Battersea Station in London, England, project barriers, facilitators and lessons learned of relevance to the Hearn's future will be highlighted and will assist the Hearn's stakeholders develop possible mechanisms and tools to ensure project success. 


\section{Methods}

\subsection{Research Question(s) and Methods}

In light of the brownfield redevelopment literature review presented above, and the Hearn's context, history, and current topicality in Toronto, the aim of the remainder of this report is to explore in-depth two precedents of sustainable urban coal plant redevelopment, and to use these case studies to form recommendations for the Hearn. In isolating and analysing salient project characteristics, enablers, barriers, and lessons learned from the redevelopment of Austin's Seaholm Power Plant and London's Battersea Station, parallels can be drawn to the Hearn that will enable Toronto's decommissioned power plant to fulfill its immense potential in the coming years. Although neither Battersea's nor Seaholm's redevelopment has been completed as of August, 2015 - Phase I of Battersea is expected to wrap up in 2016, while Seaholm will be finished later in 2015 - they nonetheless offer important planning lessons for the Hearn. While many examples of coal plant conversions exist across North America and Europe, these cases were selected as they share comparable characteristics with the Hearn, including scale, heritage value, urban waterfront location, and site context.

Thus, the central research questions addressed in this research project were:

1) What are the site history, project vision, and benefits, barriers and lessons learned from the sustainable redevelopment of Austin's Seaholm Power Plant and London's Battersea Station?

2) What are the common themes, concepts, and lessons learned shared by these two sustainable brownfield redevelopment projects; how can these inform the impending redevelopment of the Hearn in Toronto?

The first research question was answered via in-depth case study research, while the second question was answered through a synthesis and anaylsis of common themes, 
and concepts shared by the two case studies, and application to the Hearn. As stated by Neuman (2011), case study research is a form of qualitative research that has "a detailed focus but tells a larger story" (p. 42), and also facilitates the creation of richer, more comprehensive ideas and explanations. In-depth case study research into the Battersea and Seaholm redevelopment projects employed a mixed-methods technique of data collection. Firstly, robust contextual research was performed into site history, project vision, legislative framework, and development characteristics of Battersea and Seaholm. This was done through document analysis of both academic and grey literature, including promotional materials, websites, and planning documents. The information gathered from this preliminary research was then supplemented with structured key informant interviews. These key informants were selected based on their involvement with the projects under study, and included sustainability consultants, urban planners, economic development officers, members of the development team, and community group representatives. In total, 4 interviews were conducted for the Seaholm case, and 5 interviews were conducted for the Battersea case. Participants were asked a set series of interview questions, developed by Dr. Christopher De Sousa for his "Best Practices in Sustainable Brownfields Redevelopment" case study research (Appendix A), and interviews lasted from 30 minutes to 1.5 hours each. These interviews provided significant insight into project characteristics, as well as perceived barriers, enablers, and lessons learned for each project.

This detailed case study research was then qualitatively analysed by isolating important concepts and common themes. As many of these themes are of relevance to the Hearn, they were then used to develop a series of planning recommendations for the site's future redevelopment.

\subsection{Research Significance and Limitations}

As previously mentioned, the movement away from coal power generation is gaining momentum across the western world, due to the damages it causes to the environment and human health. As a result, many coal power stations are being decommissioned 
and abandoned, leaving behind important industrial heritage buildings with the potential to be redeveloped into key urban destinations and places. Interest in these sites is growing for environmental, social and economic reasons, and conducting in-depth case study research into two exemplary international projects will highlight important lessons learned for the Hearn, as well as myriad decommissioned coal plants that exist internationally. Further, the recent private and public interest in Toronto's Waterfront also gives this research project considerable significance. The Port Lands, where the Hearn is located, are some of central Toronto's last remaining undeveloped industrial waterfront properties. As a result, they contain immense potential for future city-building efforts, and the Hearn has recently been linked with a variety of redevelopment proposals that seek to capitalize on such potential. Further, with many parts of the developing world currently coal-dependent, this research also has wider-reaching global implications. As emerging economies such as China and India eventually convert to cleaner energy production, they will need similar solutions for repurposing existing power plant infrastructure for new uses.

With this said, the main limitations of this research project are its size and scope. Only two project precedents were explored in-depth, which may limit the relevance and representativeness of this study. While attempts were made to interview a wide spectrum of project stakeholders, only 9 key informant interviews were conducted in total, which likely only captures a small sample of opinions and perceptions of these projects. Further, while the two case studies have been selected for their relevance and similarity to the Hearn, they nevertheless feature different planning contexts and site characteristics. Thus, parallels between the case studies and the Hearn must be understood as guides only, rather than prescriptive formulae for development success. 


\section{In-Depth Case Studies}

\subsection{Case Study I: Seaholm Power Plant, Austin, TX}

\section{Site History}

The land on which the Walter E. Seaholm power plant now sits has been an important part of Austin's history and growth since the 1800s. This area was originally settled in 1823 by Stephen F. Austin, after whom the city is named, and served as private open ranch land until 1845 (Davis, 2006). However, the property's location at the junction of Shoal Creek and the Colorado River made it prime for industrial uses, and a flour mill was built on the site in 1845 (Meltzer, 2011). The flour mill was then renovated into a lumber mill in the 1860s, which profited greatly from Austin's newly constructed MoPac rail depot and warehouse district, which both lay adjacent to the site and eased the storage and transportation of vast amounts of lumber from the mill (Meltzer, 2011). In 1883 , on the forefront of attaining electric power, the City of Austin acquired the land just east of the lumber mill, and commissioned the city's first electric power generation plant (Meltzer, 2011). This plant would later be know as Power Plant \#1.

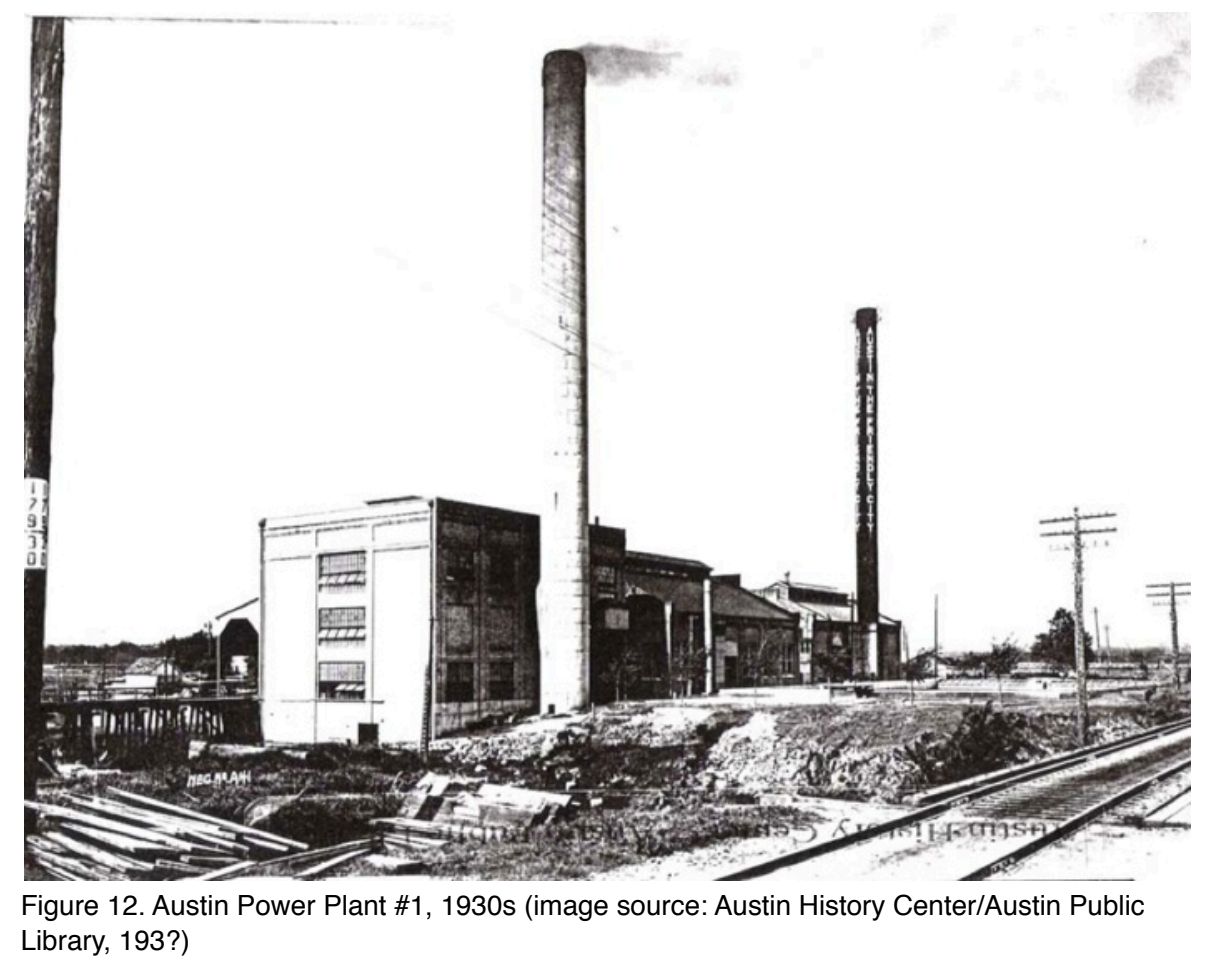


With the success of the University of Texas at Austin, the city saw steady growth through the early 20th century. Austin's expansion was compounded by a post-WWII population boom. This unprecedented population surge, coupled with increased reliance on household electric devices such as washing machines, air conditioners, and vacuums, placed enormous strain on Power Plant \#1, and the City decided to commission a new power generation facility in 1948 (Kaspar, 2013). The site of the former lumber mill, which in the 1940s had been reduced to rubble, was cleared and construction started on Power Plant \#2 (later to become the Seaholm Power Plant) in 1950 (Meltzer, 2011). Burns \& McDonnell Engineering was contracted to design a new plant (Kaspar, 2013), and a local builder, J. M. Odom, was awarded construction at a bid of \$489,830 (Meltzer, 2011). The Art Deco Power Plant \#2 was constructed in 2 phases, starting in 1950 and 1955 respectively, and the completed plant was made up of 3 buildings, the turbine generator building, water intake structure, and oil heating building (Kaspar, 2013). As was standard at the time, the plant's turbines were capable of being run by coal, crude oil, or natural gas (Davis, 2006). At the time of its completion, Power Plant \#2 housed 5 boilers and produced 100 megawatts of power

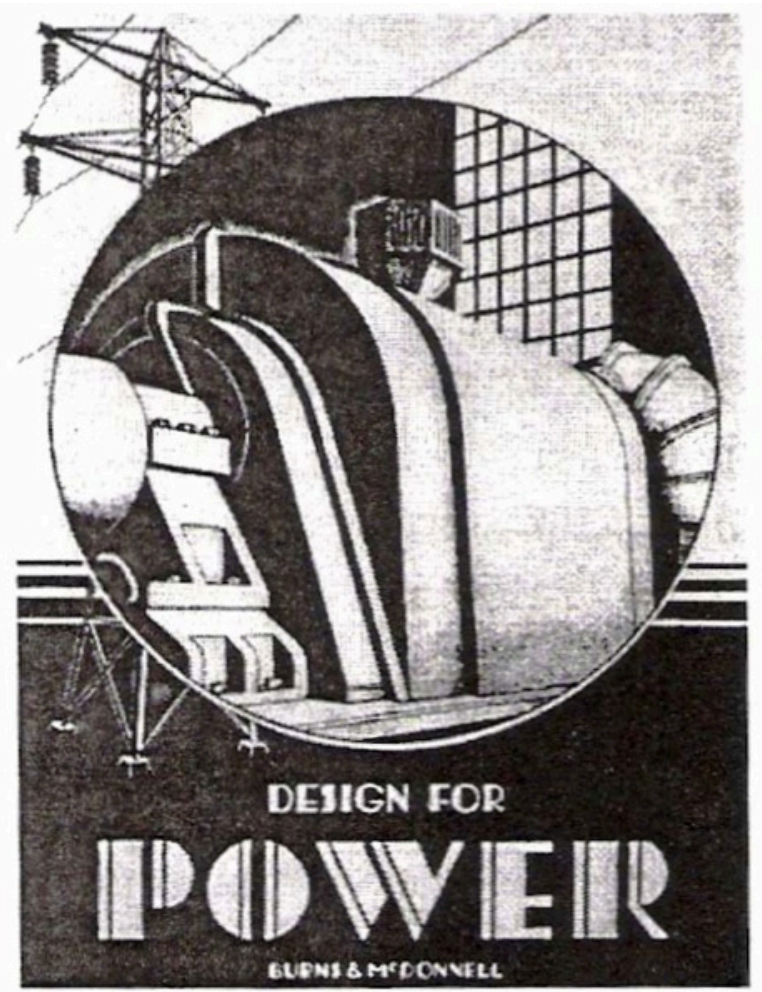

Figure 13. Advertisement for Burn \& McDonnell Engineering (image source: Austin History Center/Austin Public Library, 195?)

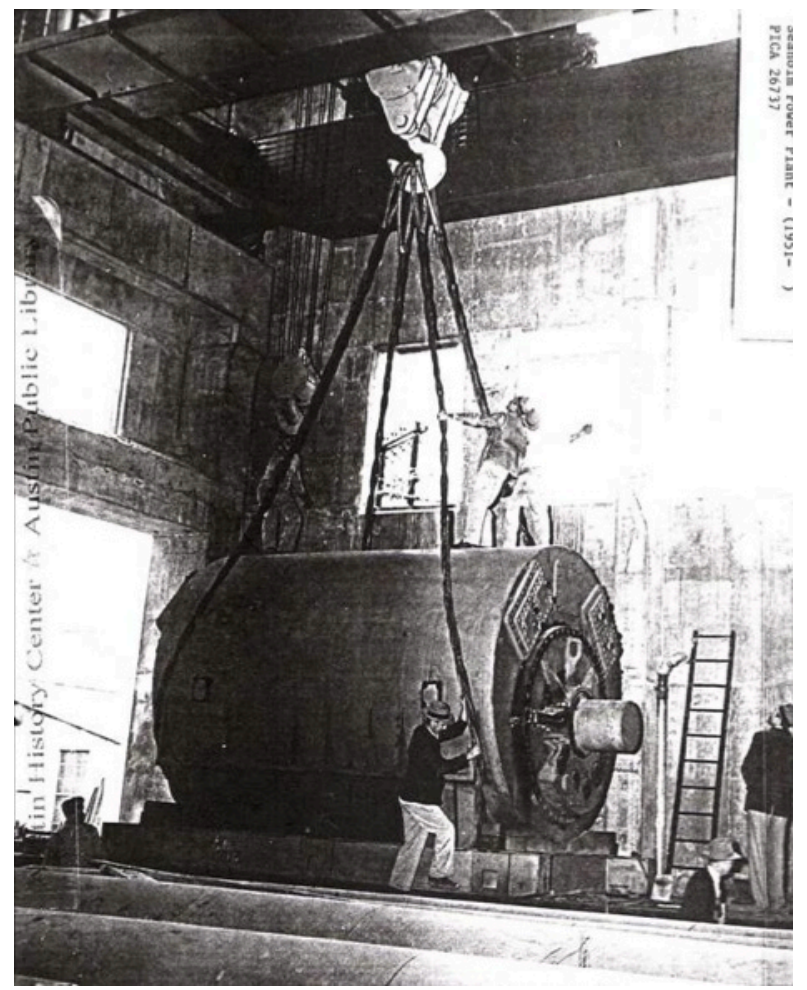

Figure 14. Construction on Austin Power Plan \#2 (image source: Austin History Center/Austin Public Library, 1951) 
(Kaspar, 2013). The plant was Austin's sole source of power from 1950 to 1959, when the city's demand for electricity outpaced Power Plant \#2's production capabilities (Kaspar, 2013). In 1960, Power Plant \#2 was posthumously named after Walter E. Seaholm, who had twice-saved Austin Power from private acquisition in 1921 and 1935 (Davis, 2006). The plant was expanded in 1972 with the addition of Austin Power office space and a loading dock (Davis, 2006).

While two additional power generating facilities were constructed on the east side of town to accommodate Austin's growing energy needs, the Seaholm Plant continued to produce energy and house the entire municipal electric department until the 1980s (Davis, 2006). During its operational life, numerous toxic byproducts were created at Seaholm, including acrid smoke and oil sludge (Meltzer, 2011). Further, while oil sludge was removed from the site for storage at a toxic waste facility, some seeped into the ground and caused contamination (Meltzer, 2011). Further, water returned to Lady Bird Lake after being used in the power generation process was often contaminated (Meltzer, 2011).

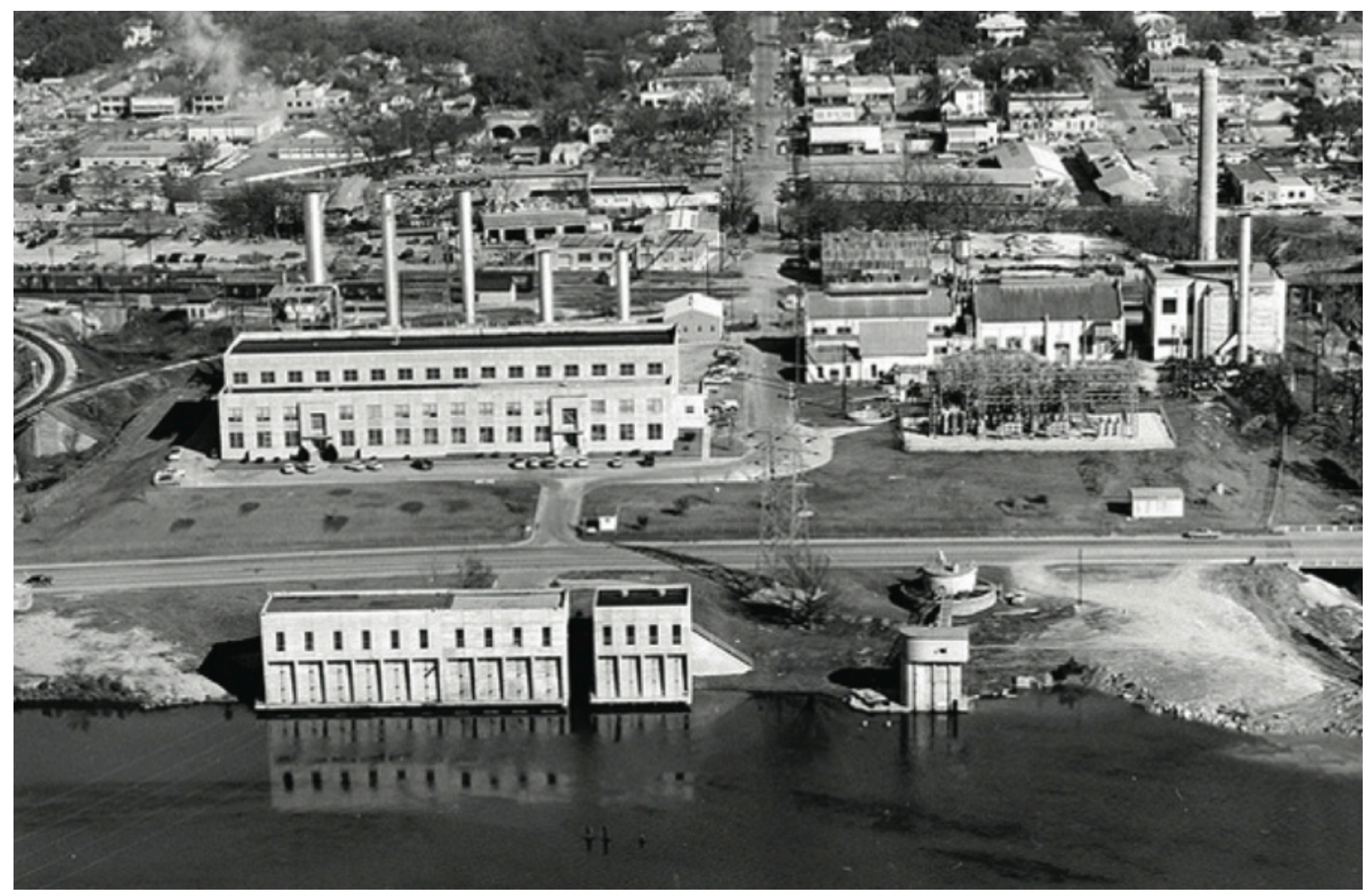

Figure 15. Austin Power Plant \#2 (later the Seaholm Plant) in the 1950s (image source: Austin History Center/Austin Public Library, 195?) 
In 1989, when operating costs at Seaholm exceeded market rates, power generation halted at Seaholm (Davis, 2006), and the plant was finally decommissioned in 1996 (TCEQ \& EPA, 2006). The building continued, however, to serve as a training facility for Austin Energy until the late 90s (Kaspar, 2013). After Austin Energy left Seaholm, the building sank into disrepair, graffiti covered its walls, and the site became increasingly cut-off from the surrounding city. While the plant had once been an important publiclyaccessible building, with Austinites visiting Seaholm to pay their electricity bills, peripheral roads became busier over time, fences were installed around the site, and the contaminated land around the plant started to leech off oil sludge, severely limiting site access (Meltzer, 2011). Despite these setbacks, Seaholm was used as an unpolished venue for arts and cultural events in the city prior to redevelopment. The massive industrial building was used by MTV to host SXSW parties, housed the Blue Lapis aerial acrobatics group, and served as a venue for numerous private events including movie screenings and shoots, all of which took place despite the building not having electricity, sewage, or water servicing (Meltzer, 2011).

\section{Project Vision}

With its history as an important part of Austin's growth, its prominent waterfront presence on Lady Bird Lake², and downtown location, community groups and the City have long been involved in the vision for Seaholm's redevelopment. In the 1980s, as the plant's future began looking bleak, local supporters united to save this iconic building (Kaspar, 2013). In the early 1980s, a community group called Friends of Seaholm was co-founded by local architect Sinclair Black and real estate agent Ken Altes, among others, with the mandate of saving the building from demolition and preserving it for public use (Kaspar, 2013). While the plant was still in operation in 1984, the City took the first step towards recognizing the building's architectural and historical significance by targeting the plant for the highest level of heritage designation (Davis, 2006).

\footnotetext{
2 Formerly called Town Lake, Lady Bird Lake is a man-made reservoir on the Colorado River. The river was dammed in 1960 to create a cooling pond for another Austin power station, the Holly Street Power Plant.
} 


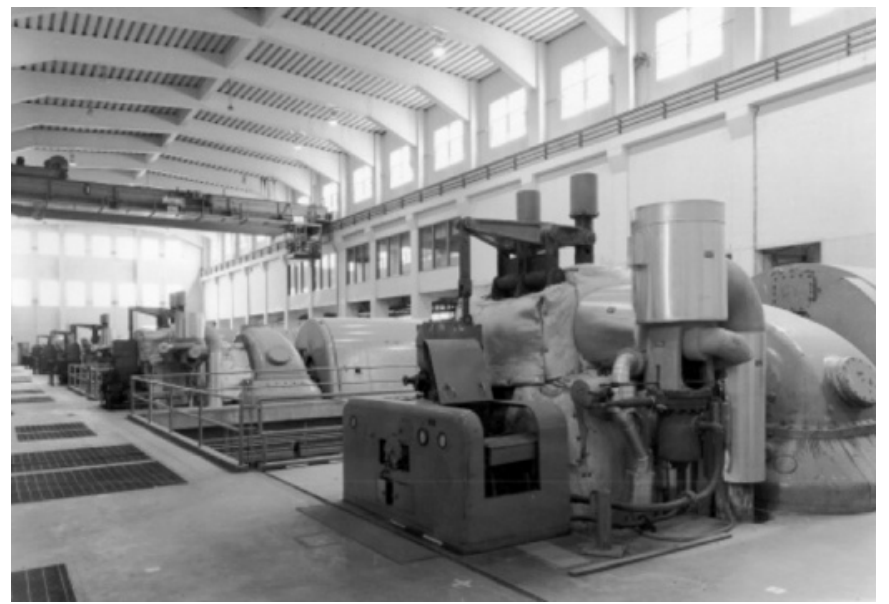

Figure 16. Interior of the Seaholm Plant, prior to turbine removal (image source: Austin History Center/Austin Public Library, n.d.)

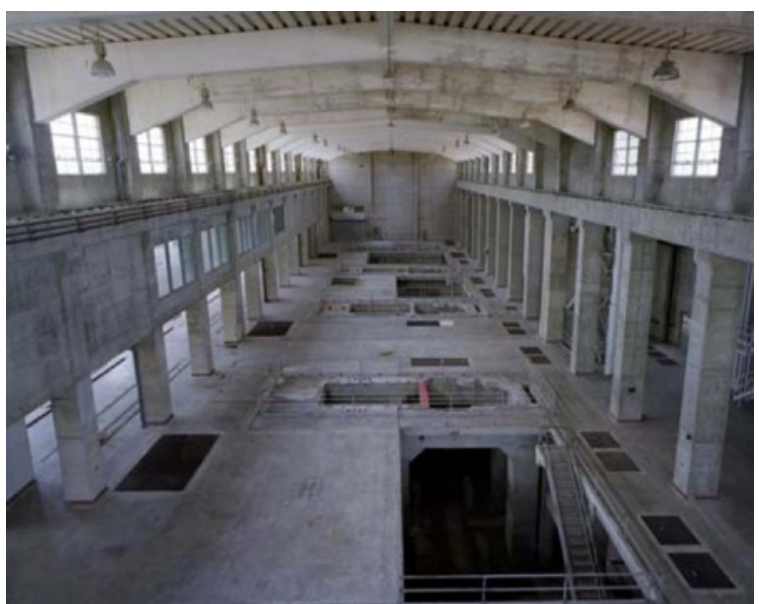

Figure 17. Interior of the Seaholm Plant, after turbine removal (image source: City of Austin, n.d.)

However, no heritage designation was finalized until several years later, and the site lay vacant and underutilized after being decommissioned in 1989. In 1996, Austin City Council made the decision to preserve the plant for public use, and made plans to remediate the brownfield site from industrial contaminants such as PCB, mercury, lead, asbestos and cadmium (Davis, 2006). The remediation was funded entirely by Austin Energy, involved the removal of all equipment from the Turbine Building (Davis, 2006), and was completed in 2006 (Seaholm Power LLC [SPLLC], 2013c).

In 1997, shortly after environmental remediation commenced, City Council formed the Seaholm Reuse Planning Committee (SRPC), which would help shape the vision for the building's reuse (Meltzer, 2011). Then, in 1998, the SRPC published their findings from a series of community consultations on Seaholm's future. Their report stated that the community believed the building was ideally suited for a major civic use (Kaspar, 2013); of 400 community members surveyed during consultations, $80 \%$ wanted to see the site used for arts and cultural purposes (Interview, June 10, 2015). Given this clear community message, City Council passed a resolution asking the City manager to provide next steps and a redevelopment proposal for the site in 1999 (Davis, 2006). Following this resolution, the ROMA design group was enlisted to create a master plan for the site in 2000 , intended to "preserve a fine example of civic architecture...create a major public attraction....and revitalize a hidden corner of downtown" (Friends of Seaholm, n.d. b). After a feasibility study of the site found that repurposing Seaholm as 


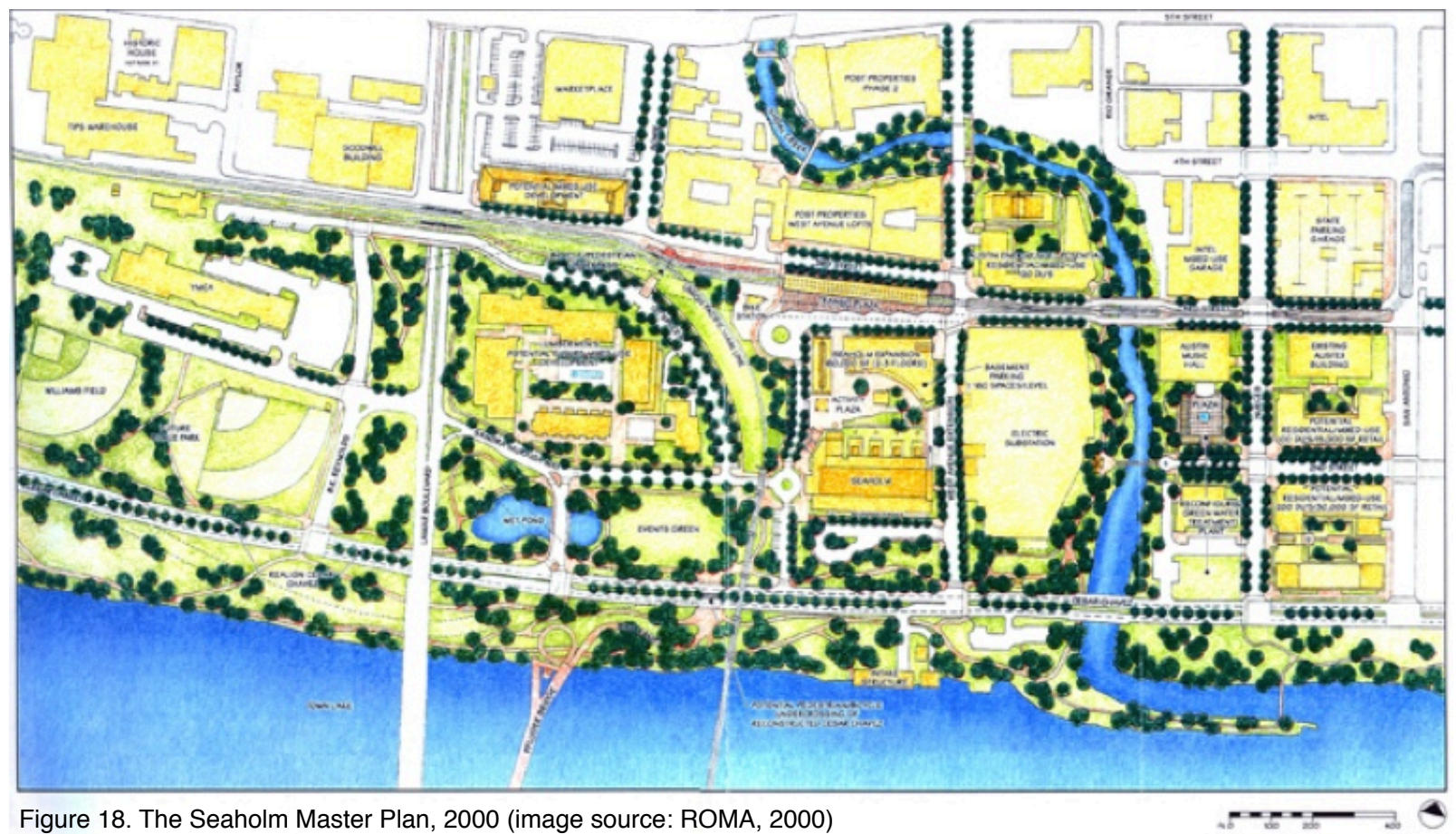

an art museum was unfeasible, owing to the fact that the redevelopment would require extensive infrastructure upgrades and would rely on Tax Increment Financing, the consultants came up with an alternate vision for Seaholm (Interview, June 8, 2015). Hence, ROMA's master plan proposed transforming not only the Seaholm Power Plant, but the entire former-industrial district on the shores of Lady Bird Lake into a vibrant mixed-use area and sought to reestablish access and connection with the rest of downtown (Friends of Seaholm, n.d. b). This would be achieved via integration with various nearby bike and pedestrian trails, extending the downtown street grid to Seaholm, and creating a rail transportation hub in the area (Friends of Seaholm, n.d. b).

Soon after the ROMA plan was created, the city started implementing many of the infrastructure improvements put forward in the master plan. Given the site's former industrial use, it had been largely cut off from the rest of the downtown throughout the last half of the 20th century. In 2002, several surrounding streets, including 3rd Street and Cesar Chavez, were extended into the Seaholm site, and the same year funding was approved for the new James D. Pfluger Bike and Pedestrian Bridge across Lady Bird Lake (Davis, 2006). These initiatives provided vital access to the site, and Pfluger Bridge was completed in 2003 (Davis, 2006). Also in 2003, Austin Energy bought 3.6 
additional acres of property to the west of the Seaholm site from the Union Pacific Railroad, which would bring the City closer to fulfilling their vision of a vibrant new Seaholm district (Davis, 2006). Further, a comprehensive downtown transportation plan issued around this time also encouraged the development of all underutilized downtown properties, and further incented Seaholm's development (Meltzer, 2011). Despite these initiatives, the Seaholm site stagnated. When the new City Hall was completed less than half a mile from the plant in 2004, interest in Seaholm peaked, as many thought land values in the area would soon skyrocket (Interview, June 20, 2015). Prompted once again by community members, City Council requested proposals from potential private development partners in 2004 (Kaspar, 2013). In April 2005, the Seaholm Power LLC (SPLLC) development team was selected to create a development plan for the 7.8 acre site that included the Seaholm plant as well as an adjacent tract of land to the north (Kaspar, 2013). The team was selected as two of its key members, John Rosato and Daniel Roth had been involved in a similar adaptive reuse project, the redevelopment of Austin's Penn Field (a WWI military airfield) into creative office and retail space (Interview, July 10, 2015). Concurrent to redevelopment plans, Seaholm was officially recorded as a Texas Historic Landmark in 2007, and listed on the National Register of Historic Places in 2013 (Kaspar, 2013). A Master Development Agreement (MDA) between the City and SPLLC was approved by City Council in 2008, which included the sale of the land north of the power plant, and a 99-year lease for the power plant itself. Thus, Seaholm's redevelopment is a Public Private Partnership (P3) between SPLLC and the City (SPLLC, 2013c).

Originally, SPLLC's vision for the site was to convert the power station into publicly accessible retail space, while developing the land north of the plant into two buildings: a 2-storey office/retail structure and a 30-storey residential hotel/condo tower (City of Austin \& SPLLC, 2008). However, following the global financial crisis in 2008, project feasibility changed, causing the developers to change their vision for the area, and to amend the original MDA to include more flexibility of uses to accommodate market fluctuations (City of Austin \& SPLLC, 2012). In 2012, the use of the power plant was changed from retail to office, and the residential tower was changed from condos to 
rental units. SPLLC then amended the MDA again in 2013, converting the rental units in the residential tower back to condos (City of Austin \& SPLLC, 2013a). Given the original vision for the Seaholm plant to perform a public civic use, and community preferences for an arts and cultural centre, the conversion of the space into private offices has received considerable community push-back. As a result, City Council only agreed to let Seaholm's ground floor be used as office space for 20 years, at which point a feasibility study will be conducted to see if retail use is tenable. If it is determined that the market will support retail at that point, the building will be converted back to retail (Coppola, 2012). Although the power plant building will be used as office space for at least 20 years, there remains a modicum of public use and access during this period. The final easement agreement for the property states that the ground floor will house a restaurant and coffee shop, public views of the historic boiler room will be maintained, and some

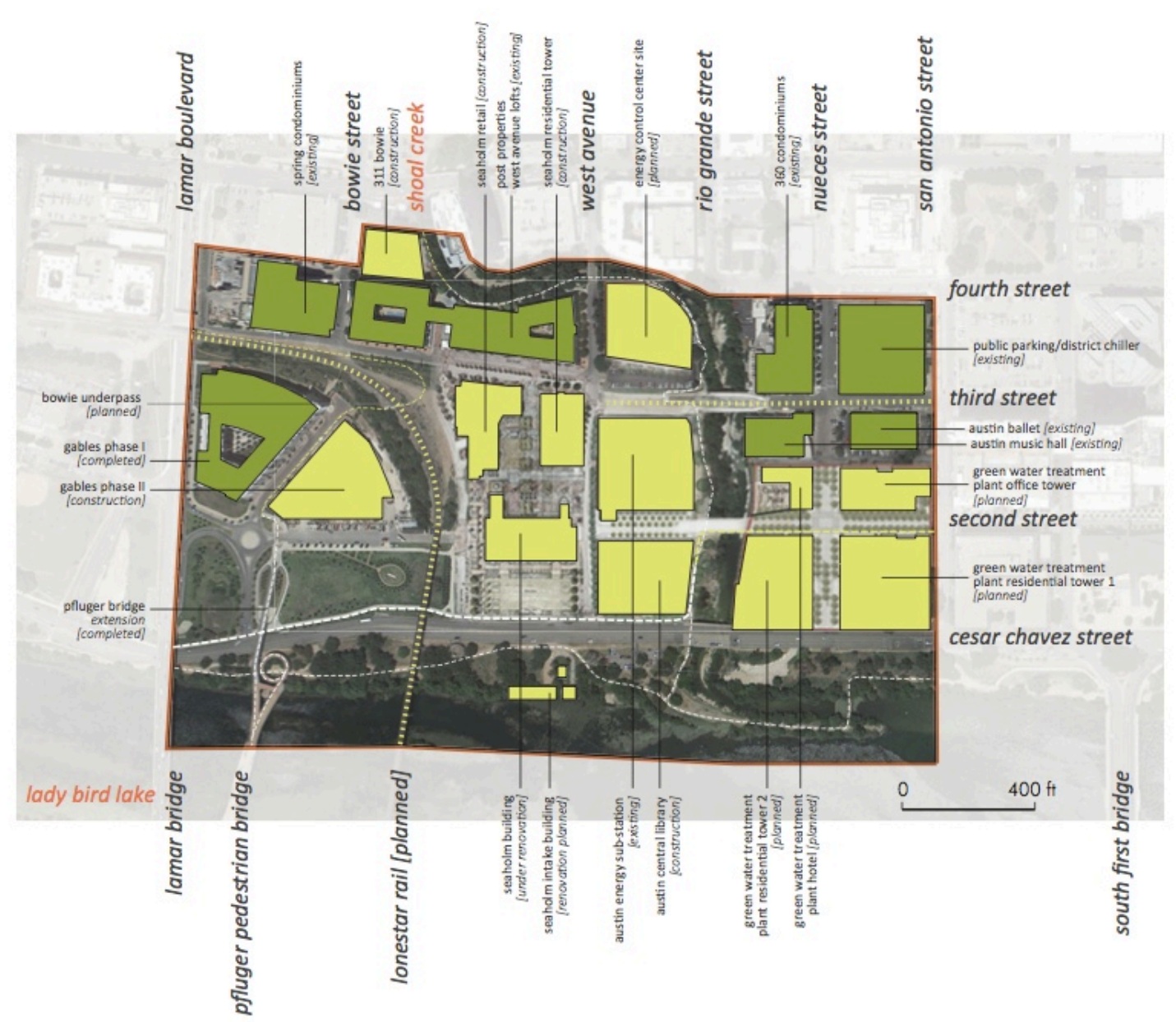

Figure 19. The Seaholm EcoDistrict (image source: Brendan Wittstruck/CMPBS, 2013) 
space will be reserved for a public art gallery managed by the City of Austin (City of Austin \& SPLLC, 2013b).

As Austin is a leader is sustainable building, and created its own green building certification system well before LEED became an industry standard (Interview, June 8, 2015), sustainability has always been an integral part of the vision for Seaholm. Thus, the project takes a triple-bottom-line approach to redevelopment. Its specific sustainability features will be discussed in greater detail later in this report. However, sustainability was stressed even further in 2012, when the City announced it would be launching an innovative EcoDistrict pilot program in the 65-acre former industrial area surrounding the Seaholm plant, known as the Seaholm EcoDistrict. The Seaholm EcoDistrict Final Report: Benchmarking + Goal Setting (Centre for Maximum Building Potential [CMBP], 2013) draws from engagement with diverse public, private, and nonprofit stakeholders to "identify quantitative and qualitative opportunities and benefits, articulate the project's sustainability vision, goals, and process, develop an action agenda, and explore how emerging tools such as ecoBalance and Visible Green can add value to the EcoDistrict framework." (CMBP, 2013, p. 8). The EcoDistrict plan also establishes eight key performance areas for the project, spanning environmental, social, and economic sustainability: equitable development, health and wellbeing, community

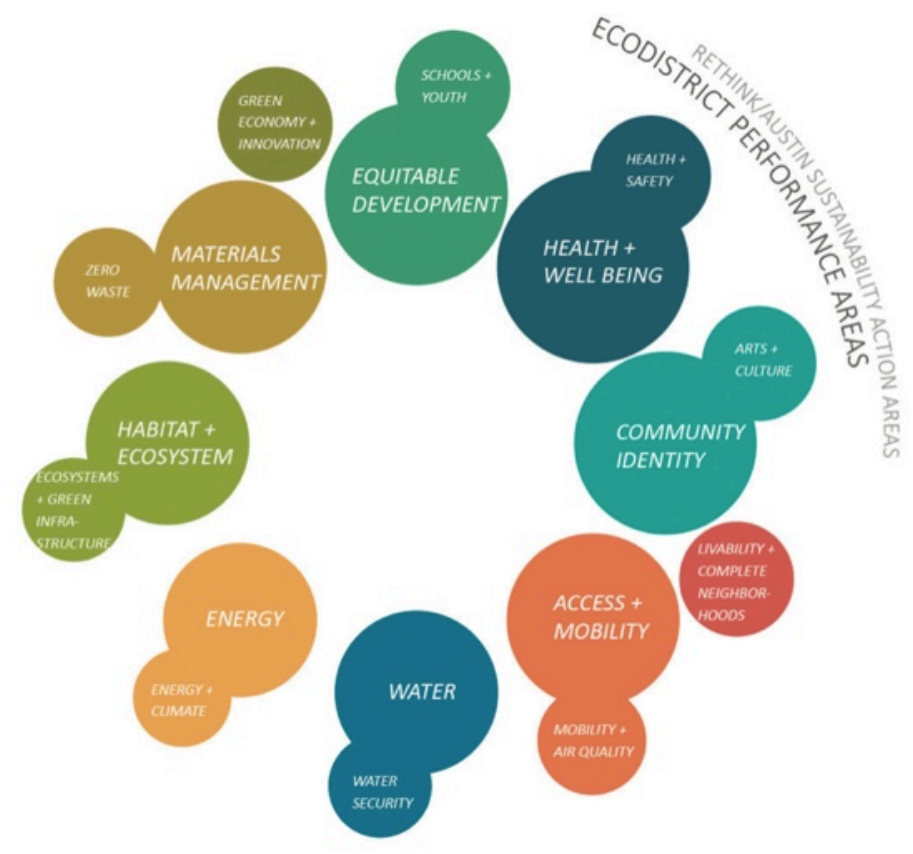

Figure 20. Seaholm EcoDistrict performance areas framework (image source: Brendan Wittstruck/CMPBS, 2013) 
identity, access and mobility, water, energy, habitat and ecosystem, and materials management (CMBP, 2013). Further, the plan also harmonizes the EcoDistrict performance areas with priorities set out in other municipal plans and policies, including the Imagine Austin Vision Plan (Austin's comprehensive municipal plan) and the Austin Office of Sustainability's Rethink/Austin Plan (CMBP, 2013).

\section{Projects Characteristics and Development}

\section{Location and Site Context}

Located on the shore of Lady Bird Lake, within the larger Seaholm District, and more broadly within the southwestern section of Austin's downtown core, the Seaholm plant is a long-standing feature of the city's landscape. Its downtown location means that Seaholm is close to many cultural institutions and venues, including the Austin Music Hall, the Austin Ballet (CMBP, 2013), the new City Hall, and the Congress Street

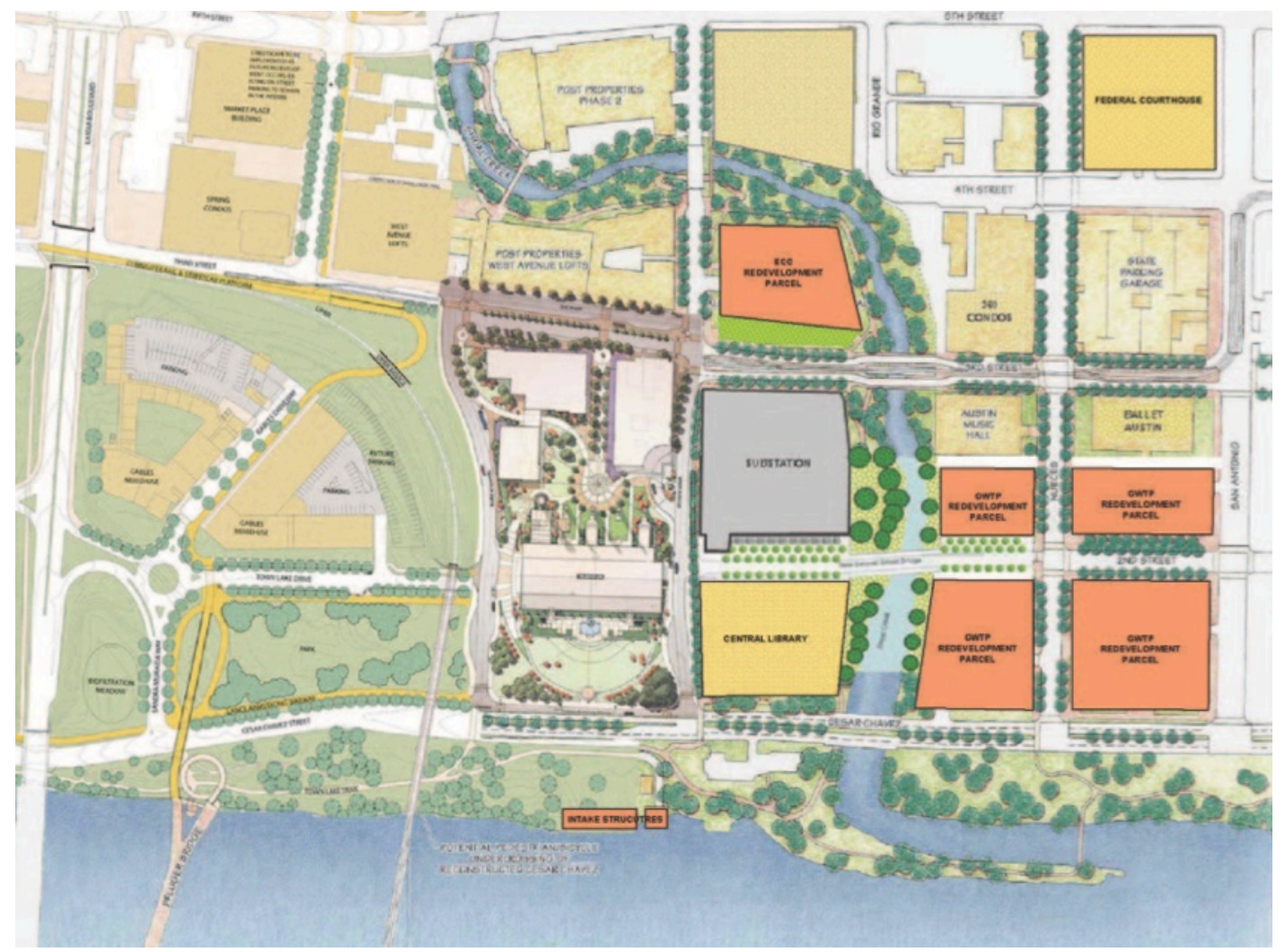

Figure 21. Seaholm Plant site context (image source: City of Austin, n.d.) 
National Register Historic District, which runs from Lady Bird Lake to the Texas State Capitol Building (Meltzer, 2011). Its proximity to the State Capital Building also means that the Seaholm site lies within a Capitol View Corridor district, which places restrictions on building heights (Meltzer, 2011). Many areas of civic use also exist around the shores of Lady Bird Lake, such as the Auditorium Shores, open green space for concerts and events, Zilker Park, the Hike and Bike Trail, and the Lance Armstrong Bikeway (Davis, 2006). The area also has enormous potential for multi-modal connectivity as a result of the Pfluger Pedestrian Bridge, several trails, including the aforementioned Hike and Bike Trail and the Lance Armstrong Bikeway, and forthcoming commuter rail line extensions into the area (CMBP, 2013).

The site is also flanked by major streets, new mixed-use and residential development and inactive and active industrial infrastructure. While the area has seen significant revitalization over the past decade, and now includes many residential, retail, and office space, remnants of its industrial past remain, and continue to pose challenges for the site and its connection with the surrounding city. For example, an outdoor electric substation immediately east of Seaholm is still in use, and a freight rail line runs directly west of the site, causing connectivity constraints. However, several actions have been taken to overcome these barriers, including building an artwall to disguise the neighbouring substation, and the possible conversion of the freight rail line into a commuter rail hub that will service the area.

\section{The Development}

The Seaholm redevelopment site itself is a 7.8 acre tract of land, which, once development is complete in 2015 , will feature the adaptively reused historic power plant and two newly constructed buildings just north of the plant. The plant is a large industrial structure made up of 4 rectangular spaces (Davis, 2006). The Plant's soaring turbine room measures 235 feet long and 110 feet wide, features 65-foot ceilings (Kaspar, 2013), and once redeveloped will house 103,000 square feet of office space. Unlike 


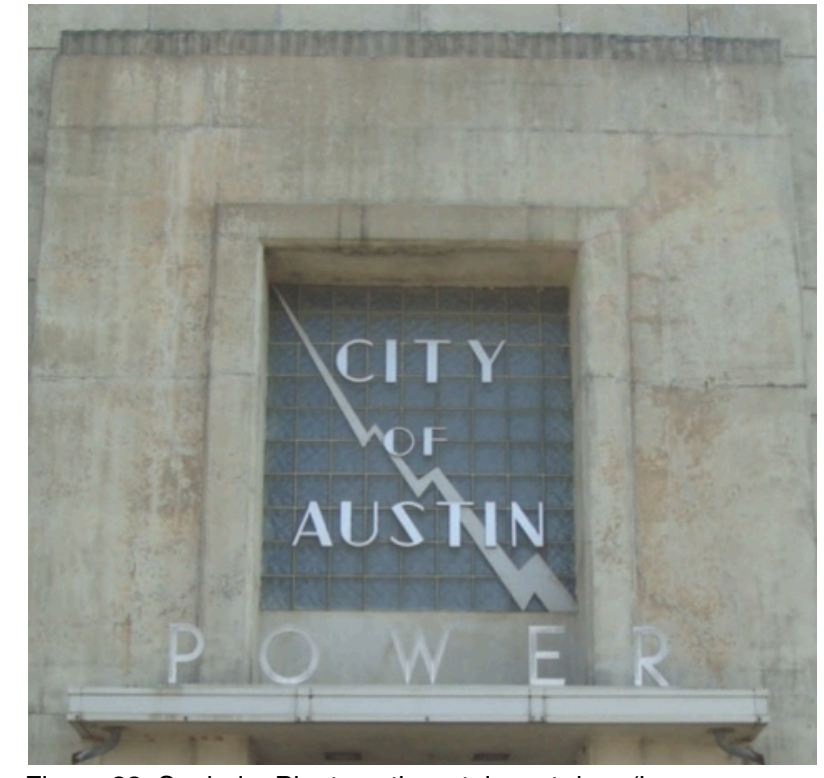

Figure 22. Seaholm Plant south portal, east door (image source: Emily Meltzer, 2011)

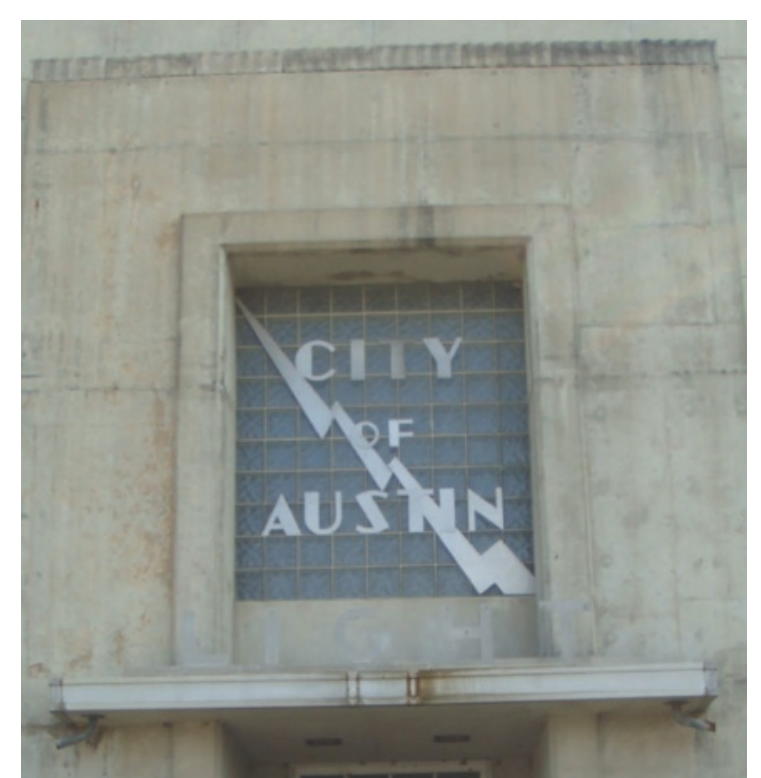

Figure 23. Seaholm Plant south portal, west door (image source: Emily Meltzer, 2011)

many other North American power plants of the time, Seaholm is a semi-outdoor plant ${ }^{3}$ constructed of site-cast concrete, a departure from typical power plant masonry work (Davis, 2006). The Seaholm Plant also features Art Deco architectural detailing, which is one of the reasons why local citizens have been so ardent about preserving the building in lieu of demolition. Perhaps the most iconic elements of the plant are the two large Art Deco Moderne signs that adorn the building's main entrances; the eastern one reads City of Austin Power, while the western one reads City of Austin Light. As Seaholm has been listed on the National Register of Historic Places since 2013, the current owner or lessee cannot alter any exterior elements of the building (Meltzer, 2011). The two newly constructed buildings north of the plant include a residential tower and a 2-storey lowrise retail/office building. The 30-storey residential tower will include 280 condo units, while the low-rise building will include nearly 50,000 square feet of retail space, and additional office space. The redevelopment project also includes 1.5 acres of public space, including a public plaza between the power plant and the newly constructed buildings, and a landscaped 'front yard' just south of the Seaholm Plant (SPLLC, 2013a).

\footnotetext{
3 This means that Seaholm's generators were housed within the plant, while it's boilers were located outside. This style of power plant is suited to temperate southern climates (Davis, 2006).
} 


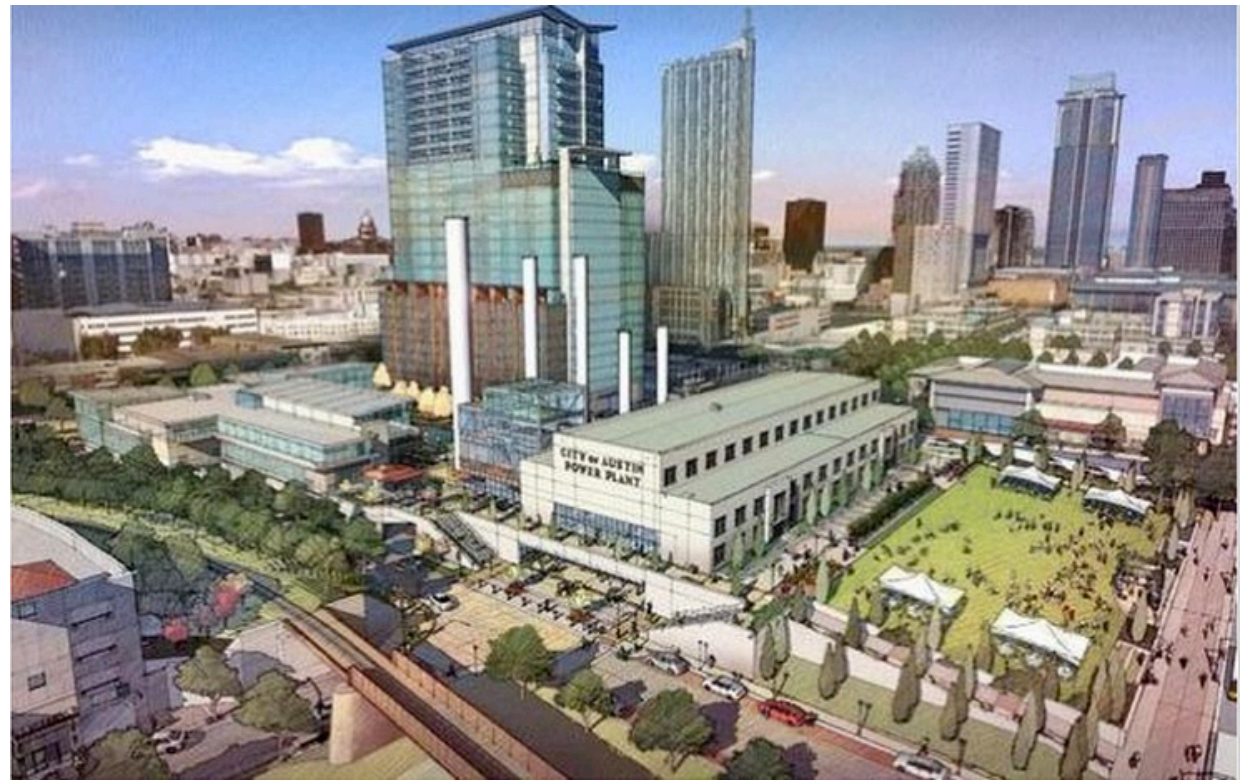

Figure 24. Rendering of the new Seaholm development site (image source: SPLLC, n.d.)

Many of the development's office and retail tenants were secured long before project completion. Athenahealth, a healthcare software company, leased all of the office space in the historic Seaholm Plant in 2014 (Buchholz, 2015), while Connected Fitness, a subsidiary of sportswear company Under Armour agreed to rent the office space in the the newly constructed low-rise building early in 2015 (Under Armour, 2015). The retail portion of the low-rise building will be occupied by a Trader Joe's, who was the first tenant to be secured for the site, in 2012, while the refurbished ground floor of the Seaholm Plant will house an 11,000 square foot restaurant called Boiler 9 (an homage

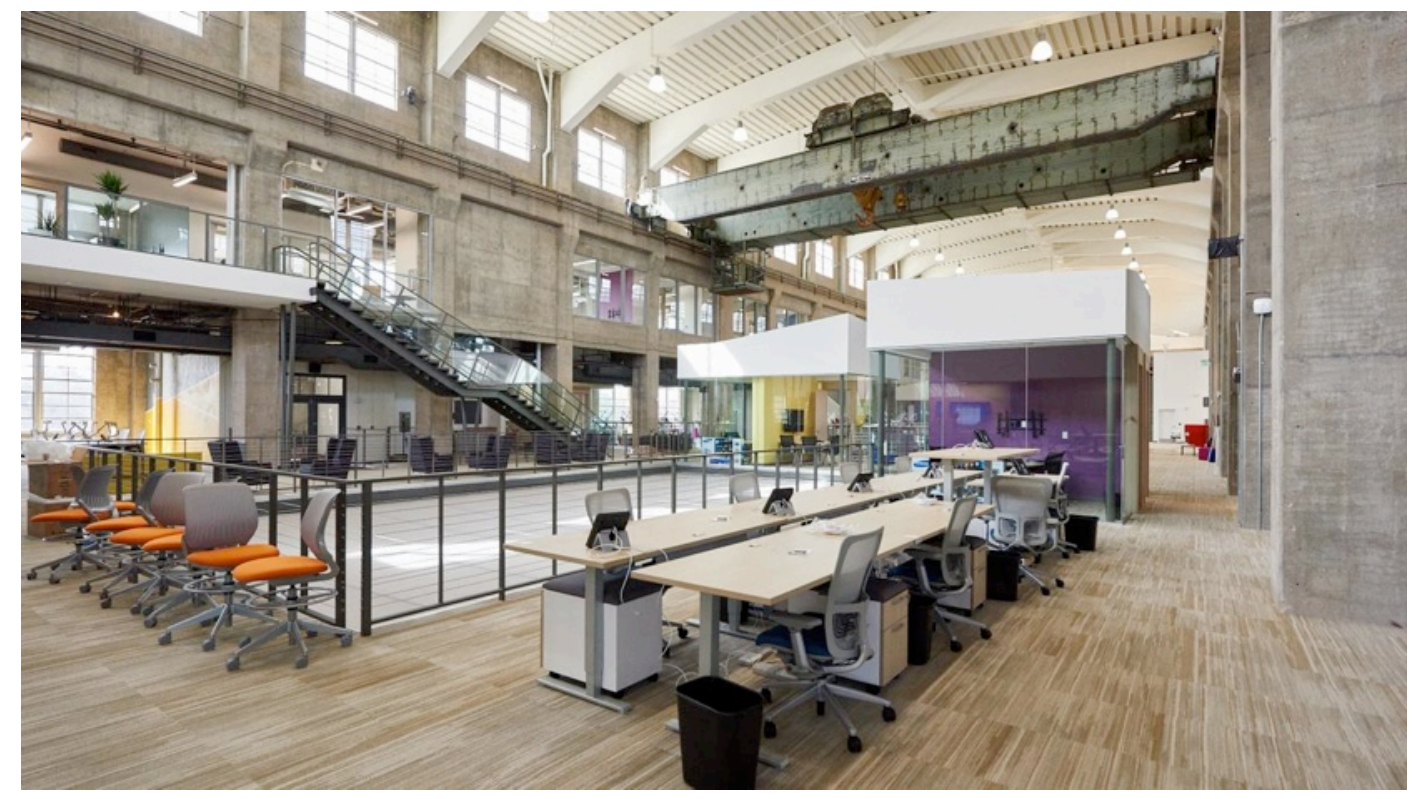

Figure 25. Interior of the redeveloped Seaholm Plant, as Athenahealth offices (image source: Nick Simonite/ Austin Business Journal, 2015) 
to the building's industrial history), as well as 3,500 square feet of public space, including a coffee shop (Novak, 2014).

Further, the desirability of the Seaholm redevelopment was highlighted when the condo units in the residential tower went on sale in 2013. As downtown Austin's first new condo building in six years, nearly all units, which ranged in price from $\$ 300,000$ to over $\$ 1$ million, were reserved within a week, a record for downtown projects (Kaspar, 2013).

\section{Sustainability Features}

Besides the preservation of the original heritage power plant discussed above, the project includes several additional environmental, social and economic sustainability components. Firstly, the choice to adaptively reuse the Seaholm Plant, instead of demolishing it, demonstrates both environmental and social merit, as demolition would have resulted in significant material and energy wastage (Interview, June 20, 2015). As Austin has been a pioneer in sustainable building, the City created their own sustainable certification, the Austin Energy Green Building system, before LEED was an industry standard. Thus, the Seaholm project is aiming for an Austin Energy Green Building Two Star Certification for the power plant itself, and Austin Energy Three Star for the newly constructed buildings. The project is also aiming for a silver or higher LEED certification (SPLLC, 2013b). However, attaining energy efficiency in the heritage Seaholm Plant has been a challenge (Interview, June 20, 2015). The extensive site remediation completed by Austin Energy prior to entering into a development agreement with SPLLC also contributes to on-site sustainability, although the dig-and-dump method used for soil remediation (TCEQ \& EPA, 2006) does not demonstrate sustainability best practices. The $\$ 13$ million cleanup was funded entirely by Austin Energy (thus, indirectly, Austin taxpayers footed the bill), supervised by URS, took 9 years to complete, and

involved decontaminating soil, replacing the plant's roof, and dismantling and removing equipment (Meltzer, 2011). As a result of the site's long industrial use, contaminants such as lead paint, asbestos, PCB, mercury and cadmium were found in various media on-site and had to be remediated (Kaspar, 2013). Following cleanup, Seaholm was the 
first facility in the US to be designated 'ready for reuse' under the Federal Toxic Substances Control Act by both the Texas Commission on Environmental Quality and the US EPA (Kaspar, 2013).

The project will also reuse Seaholm's valuable industrial infrastructure for sustainability purposes. The plant's massive underground cisterns, once used to cool water from the plant during the energy production process, will be reused to store rainwater for on-site irrigation. This means that the development will not require any City water for irrigation purposes (SPLLC, 2013b) As previously mentioned, the development will also include 1.5 acres of new public green space. Although initial estimates by the Center for Maximum Potential Building (CMPB, 2013) found significant on-site potential to use surface areas in the Seaholm redevelopment area for energy production via photovoltaics (solar panels), and original plans to use the Power Plant roof for this purpose, this plan will likely not be realized, due to technical problems and constraints (Interview, June 8, 2015).

Incorporating multiple modes of transportation into the development project is also a significant sustainability feature. Besides featuring connectivity to numerous nearby pedestrian and bicycle trails, the site will also feature charging docks for electric cars, bikeshare and carshare facilities, and substantial bicycle parking (Interview, June 8, 2015). Further, the City is planning to create a crosstown collector rail hub nearby, which will repurpose the freight line that runs directly west of Seaholm, and will ease sustainable travel to and from the mixed-use development site (SPLLC, 2013b).

As the Seaholm redevelopment project involves revitalizing formerly underutilized and derelict industrial lands, the project will also have a considerable effect on the City's economic development. The entire re-development project includes a total investment of over $\$ 130$ million, $\$ 24.5$ million of which will be invested by the City (McCrady, 2013). The whole Seaholm District is projected to bring 2,000 jobs into the area (EcoDistricts, 2012), including over 600 permanent positions with Athenahealth over the next 10 years, with an average salary of $\$ 130,000$ (Kaspar, 2013). Athenahealth has also 
pledged to invest $\$ 13$ million in a research and development centre at Seaholm (Kaspar, 2013). Further, allowing flexibility in the MDA to adapt to market conditions also contributes to the project's financial viability and sustainability. As is standard City protocol (Interview, June 8, 2015), the MDA for the development also stipulates that a certain proportion of on-site jobs and businesses be targeted to women and minorities (City of Austin \& SPLLC, 2008).

Apart from equal opportunity hiring, the development project has also incorporated several social sustainability measures, including the preservation and adaptive reuse of the heritage-designated Seaholm Power Plant itself. Planning a development with mixed uses, incorporating active transportation facilities, and public spaces into the development can also be considered elements of social sustainability, as they will create a vibrant, walkable, and healthier community. However, one interviewee noted that the development's public space is limited, given the scale of the project (Interview, June 10, 2015). Further, the community has been highly involved in the preservation and revitalization of the area from the outset, as the City mandates that local citizens be consulted with regards to development plans (Interview, June 8, 2015). With that said, public participation at Seaholm has been criticized for being largely tokenistic, and some community members feel that the new office use for the Seaholm Plant does not adhere to the 'civic public use' mandated in early visioning for the site (Interview, June 10, 2015). Further, the most recent change to the MDA, which converts all units in the residential tower from rental to condos, means that the City cannot mandate affordable housing be included in the development itself (Interview, June 8, 2015); had the units been rental, the developer would have had to include $5 \%$ social housing for 40 years (City of Austin \& SPLLC, 2013b). However, whenever City property is sold, a portion of the profits go into a trust fund for affordable housing elsewhere in the city, meaning that SPLLC did have to contribute to social housing, just not on-site (Interview, June 8, 2015). It has also been noted that there is not affordable housing anywhere in the Seaholm District (Interview, June 20, 2015). As a result, the residential units will only be occupied by those who can afford the steep market price of the in-demand Seaholm condos, and thus will not likely create a diverse and resilient community. It is also 


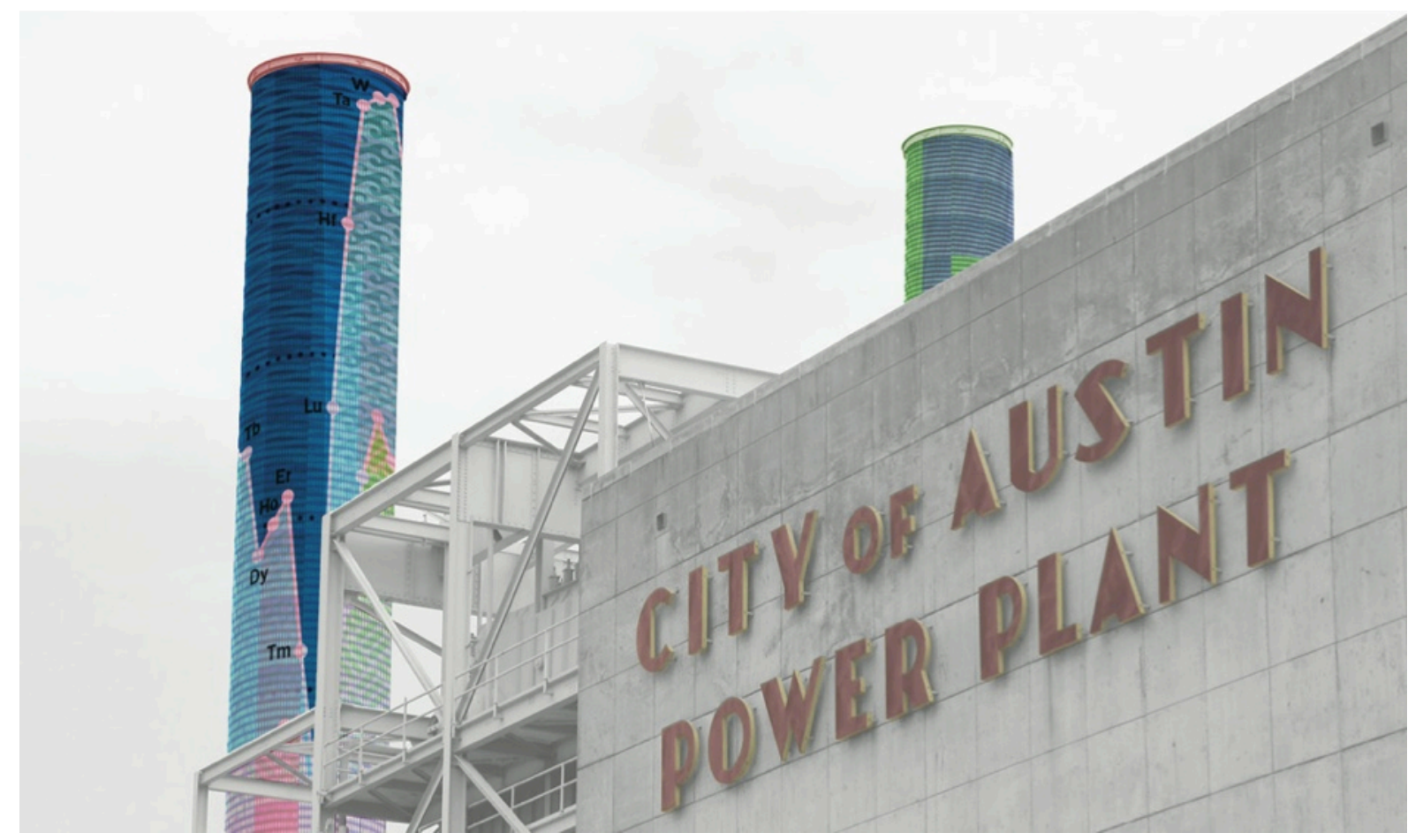

Figure 26. Rendering of Seaholm stacks interactive environmental media project (image source: Brendan Wittstruck/CMPBS, n.d.)

interesting to note that the official vision for the Seaholm development posted on the SPLLC website includes environmental, economic development and transportation features of the project, but little mention of social sustainability.

Despite these shortcomings, Seaholm will also be used as a forum for fostering education and awareness of sustainability. As such, the MDA stipulates that a portion of the power plant's ground floor be reserved for public displays on sustainable development, while a proposal for didactic elements throughout the Seaholm District was created by CMPBS in tandem with the EcoDistrict plan (Interview, June 20, 2015). This proposal includes sustainability signage and wayfinding, an eco-cafe, and an interactive environmental media project that will project sustainability metrics and performance on the Seaholm stacks (CMPBS, n.d.).

\section{Project Funding}

As previously mentioned, the Seaholm redevelopment project will require funding of over $\$ 130$ million, $\$ 24.5$ of which will be contributed by the City, making it an example of 
a public private partnership (McCrady, 2013). The partnership was created by the City in order to cover the enormous costs of preserving and redeveloping the Seaholm Plant (Kaspar, 2013). As noted by Kaspar (2013), Seaholm's "lakefront site would have generated more income had it been razed, making way for a much taller structure." Due to the financial risk associated with redeveloping this site, and uncertain economic conditions following the 2008 global financial crisis, the project start was delayed, and financing had to be secured twice over the course of the development (Kaspar, 2013). According to the 2008 MDA between the City and SPLLC, the developer bought the residential tower site and low-rise office/retail site from Austin Power for $\$ 2,000,202$, and $\$ 915,000$ respectively (City of Astin \& SPLLC, 2008). They also entered into a 99year lease for the Power Plant at the cost of $\$ 1$ per annum (City of Astin \& SPLLC, 2008).

Further, the City's contribution to the development will be covered by a variety of funding sources, including Tax Increment Financing (TIF), which is projected to generate $\$ 15.4$ million over 30 years, parking garage fees, which will raise $\$ 9.9$ million, and a portion of the area's sales tax, which will contribute \$2.7 million (McCrady, 2013). SPLLC will also receive infrastructure incentives from the City if they perform in a timely way, thus acting as a performance tool for the project to ensure timely development of the site (Interview, June 8, 2015). Despite the preservation and adaptive reuse of the heritage-designated Seaholm Plant, the developer was not eligible for Historic Tax Credits, as some of the energy saving fixtures used in the plant compromised the building's heritage character (Interview, June 20, 2015).

Another source of indirect project funding came in the form of public subsidies to the site's tenant, Athenahealth, which allowed the company to lease the Seaholm Plant's entire 103,000 square feet of office space for 10 years (Kaspar, 2013). This, in turn, contributed to the success and viability of Seaholm's redevelopment. The final deal between Athenahealth and the developer was struck in January 2014, just after Austin City Council approved $\$ 679,500$ in incentives over the next 10 years, and the Texas Enterprise Fund awarded the company $\$ 5$ million (Novak, 2014). 


\section{Lessons Learned: Project Enablers and Barriers}

Consistent with brownfields literature (Lange \& McNeil, 2004), interviews with various Seaholm stakeholders highlighted the often incongruous definitions of success in brownfield redevelopment projects. Some common enablers, barriers and lessons learned from the project were nevertheless identified. As is also seen in the literature, a prominent link between project success and economic viability (Howland, 2007) was also noted by City officials and consultants, while environmental and social effects played second fiddle.

One common factor linked with project success was the iconic status of the Seaholm Plant, and a strong shared vision between the City, the developer and community members of preserving the building. In fact, the love that Austinites have for Seaholm, and broad political support for the project were cited by all interviewees as critical catalysts for Seaholm's transformation. Similarly, the importance of the developer was also highlighted by interviewees. It was noted that involving a local developer with a combination of vision, commitment, and patience was important, as he "did it for the love of the project" (Interview, June 8, 2015), and not solely for financial gain. One interviewee went as far as saying they were unsure how the developer had made a profit on the project, given its numerous constraints (Interview, June 8, 2010). Further, the developer's personal interest in sustainability was also raised as being pivotal to the project's strong sustainability mandate (Interview, July 10, 2015). As Austin prides itself as being at the forefront of green building, the City's culture of sustainability also ensured that the project took a triple-bottom-line approach (Interview, June 8, 2015). It was also noted that the iconic heritage-designated Seaholm Plant, and its prime central waterfront location added value to the development, and increased project feasibility in the face of significant time and cost requirements (Interview, June 20,2015). Heritage is a particularly rare and valuable commodity in Austin, as it is a relatively new city with a paucity of old industrial buildings (Interview, July 10, 2015). The impact that residential 
uses made on the feasibility of this adaptive reuse project was also mentioned (Interview, June 20, 2015).

Another enabler of the project is that the Seaholm site continues to be publicly owned, and that the project is based on a P3 model. As Austin Energy is the City's "cash cow" (Interview, June 8, 2015), this made the $\$ 13$ million public remediation of the site possible before redevelopment, thus increasing project viability. It was also noted that having a strong P3 agreement that includes effective performance tools is also important to project success (Interview, June 8, 2015). In the case of the Seaholm MDA, infrastructure incentives were used to ensure that the developer completed the project components in a adequate and timely manner (Interview, June 8, 2015). The project's P3 structure also allows the City to maintain more control over the development, and to ensure that it maintains features that benefit the greater good (Interview, June 20, 2015). It was also noted that a flexible and outcome-oriented rather than prescriptive MDA ensured that various market fluctuations could be accommodated, and feasibility preserved over the project's extended timeline (Interview, July 10, 2015). Further, the use of value-capture revenue tools such as TIF, sales tax capture, and parking rates, also helped the project get off the ground. The importance of setting clear goals for the redevelopment from the outset, as well as constant evaluation of progress towards these goals was also raised as important for project success (Interview, June 8, 2015).

Infrastructure was also raised as a pivotal determiner of success at Seaholm. First, the importance of providing supporting infrastructure was stressed, as the former-industrial Seaholm district was isolated and inaccessible prior to redevelopment. Thus, creating multi-modal transportation links and connections before redevelopment, such as the Pfluger Pedestrian Bridge, the Lance Armstrong Bikeway and various street extensions into the district was instrumental in the project's success (Interview, June 10, 2015). It is also notable that a commuter rail extension for the area is being investigated, although the extreme cost of such an undertaking makes the project trajectory unclear (Interview, June 8,2015$)$. Although not mentioned explicitly by interviewees, the reuse of industrial infrastructure for environmental purposes, such as using Seaholm's cooling tanks as 
rainwater catchment cisterns, is also a critical enabler of sustainability in this project. The creation of the Seaholm district is hence also an important facilitator of project success, as many of these wide-scale infrastructure projects are only possible within a broader urban context.

Several important project barriers were also raised by interviewees, but these, again, highlighted discrepancies between different stakeholder definitions of project success and failure. For example, community members unhappy that the Seaholm Plant was not redeveloped for major civic and cultural use described barriers to seeing their vision for the site realized. Namely, these included financial barriers, such as the inability for the City to call a Bond Election to raise funds for the project, which resulted in City enlisting a private developer to partner in the project (Interview, June 10,2015). City officials also noted financial barriers to transforming the plant into a museum; due to costly infrastructure upgrades and adaptive reuse, the redevelopment needed to provide increased property tax and sales tax potential in order to qualify for TIF, which would not have been possible with a museum (Interview, June 8, 2015). Market fluctuations over the project's extended timeline were also cited as barriers to Seaholm's redevelopment, as the great recession delayed the project start, and financing had to be secured twice (Interview, June 8, 2015).

The lack of meaningful community consultation, and paucity of affordable housing and parkland on site were also described by community members as barriers to the project's success (Interview, June 8, 2015). With this said, City officials and consultants noted that the long drawn-out public process in Austin was an impediment to Seaholm's redevelopment. This points to larger policy issues, as lack of appropriate and efficient regulations - with regards to affordable housing, sustainability, community engagement and development review - was noted by all interviewees as detracting from the project's potential.

The fact that the EcoDistricts project was initiated after Seaholm's MDA had already been signed was also raised as a barrier to seeing more sustainability features in the 
project (Interview, June 20, 2015). This again highlights the need for front-ended timing with regards to establishing goals and targets for the project. Some interviewees also mentioned lack of market demand for sustainability and a NIMBY anti-growth mentality in Austin as project barriers (Interview, June 20, 2015). However, branding the district and bringing increased awareness to sustainability via didactic features such as signage and multimedia displays was thought to be an effective way to tie sustainability into the Seaholm 'brand' and to educate citizens that development and sustainability are not always oppositional (Interview, June 20, 2015).

More broadly, the various barriers to Seaholm's redevelopment mentioned above highlight the conflicts that often exist between the three pillars of sustainability: the environment, the economy, and the community. This can be illustrated in several examples touched on throughout this report, the most telling of which is the tension between heritage preservation (which is an element of social sustainability), energy efficiency, and economic viability. Not only did the development team struggle to achieve Austin Energy Green Building requirements due to the massive interior space of the Power Plant, they were also unable to qualify for Historic Tax Credits due to the installation of energy efficient windows in the plant (Interview, June 20, 2015). 


\subsection{Case Study II: Battersea Power Station, London, UK}

Site History

Located in what is now central London, on the banks of the Thames River, Battersea Station has been a symbol of Britain's industrial power since its initial construction in the late 1920s. In the first half of the 20th century, electricity was produced in Britain by a variety of private and municipal actors, but was managed and distributed by the Central Electricity Board (CEB) (Heathorn, 2013). After the 1926 conservative British government vowed to provide cheap electricity to all citizens, the decision was made to locate power as close as possible to end users, to reduced the immense costs of electrical transmission lines (Heathorn, 2013). The CEB joined forces with the private London Power Company (LPC) and selected Battersea as an ideal site for a massive coal power plant that would help supply London's growing electricity demands (Heathorn, 2013). The site's riverfront location allowed the plant to be cooled with river water, while large amounts of coal could be shipped via barge from northeast England (Jackson, 1984). The banks of the Thames had always been important to London's industrial history, and the authorities decided that the former Southwark and Vauxhall Waterworks Company reservoirs site would be ideal for a new power station (GLA, 2009b). These reservoirs had been constructed on the banks of the Thames in 1855, following a cholera outbreak and subsequent Act of Parliament requiring increased water purity and filtration in London (Mukhopadhyay, 1975).

In 1927, final consent was given to build a huge power station, later known as Battersea A, in the heart of London (Bowler \& Brimblecombe, 1991). The power station would be built in two stages, and would produce 400 megawatts of power once completed (Battersea Station Community Group [BSCG], n.d. b). When plans for the station were announced, local residents opposed construction due to concerns about pollution, and the negative visual impact of the monolithic structure (Heathorn, 2013). However, the CEB and LPC quelled community fears by insisting that the station would emit less pollution and consume less coal than the three obsolete plants it was slated to replace 


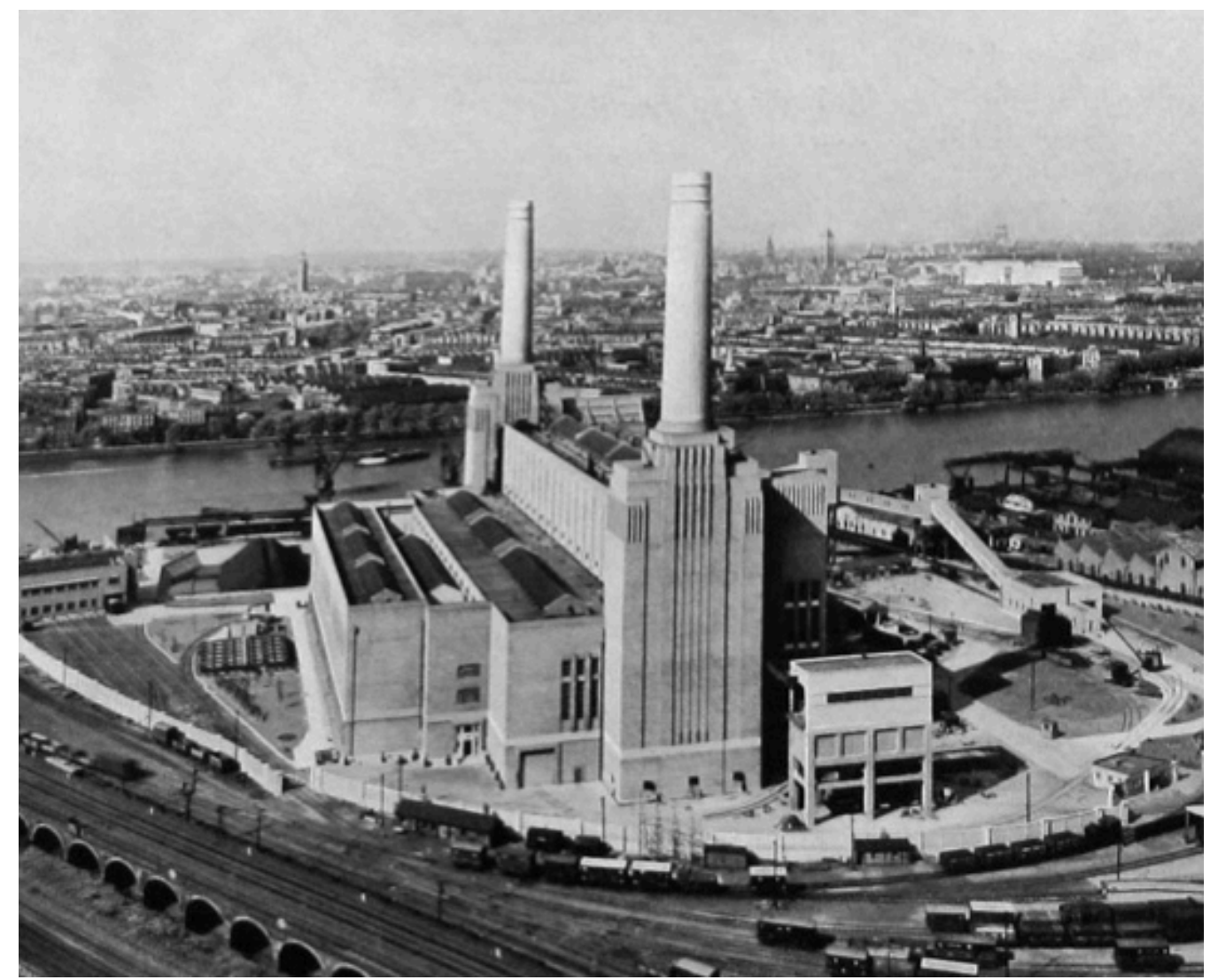

Figure 27. Battersea A, 1935 (image source: London Metropolitan Archives, 1935)

(Heathorn, 2013). This would end up being untrue, as Battersea's 'state of the art' flue gas scrubbers and coal washing caused significant air and water pollution over its lifespan (Heathorn, 2013). In order to combat aesthetic concerns, the LPC enlisted famed architect Sir Giles Scott to design the power station, with the mandate of creating a distinguished, architecturally interesting building (Heathorn, 2013). Scott fulfilled this vision, as Battersea's sublime design details and towering neoclassical fluted columns made it an architectural triumph. Battersea A was constructed between 1929 and 1935, and was originally comprised of one turbine hall and two chimneys (GLA, 2012). In 1939 a panel of renowned architects named the power station "the second best building built in Britain in recent years" (Heathorn, 2013, p. 131).

Following WWII, and London's subsequent population boom and increased reliance on household electric appliances, an addition was planned for Battersea Station. By this point, the private London Power Company had been bought out by the public British Electric Authority when power was nationalized in 1948 (BSCG, n.d. b). Known as 
Battersea $B$, this new wing was a mirror-image of the original power station, added another turbine hall and two additional chimneys to the station, brought the station's generating capacity to 509 megawatts (BSCG, n.d. b), and was completed in 1955 (GLA, 2012). The two buildings together formed Battersea's iconic 4-chimneyed structure. By 1960, Battersea was the engine behind London's rapid growth; it sat on a 15-hectare site (GLA, 2009b), drew 340 million gallons of water from the Thames daily, and consumed almost a million tons of coal each year (Heathorn, 2013). Further, at its peak Battersea supplied a fifth of London's power, and employed nearly 1,000 people (Battersea Power Station Development Company [BPSDC], 2014b). To this day, Battersea remains the largest brick building in Europe (BSCG, n.d. b).

With the advent of the supergrid in the 1950s, transporting electricity via long-distance transmission lines became increasingly cost-effective (Heathorn, 2013). This meant that new plants could be located on the English coast, as opposed to within central cities, making Battersea's role as one of London's principal energy producers tenuous. Despite this, Battersea became an increasingly celebrated icon of London and British culture more generally through the later half of the 20th century, and was featured in numerous

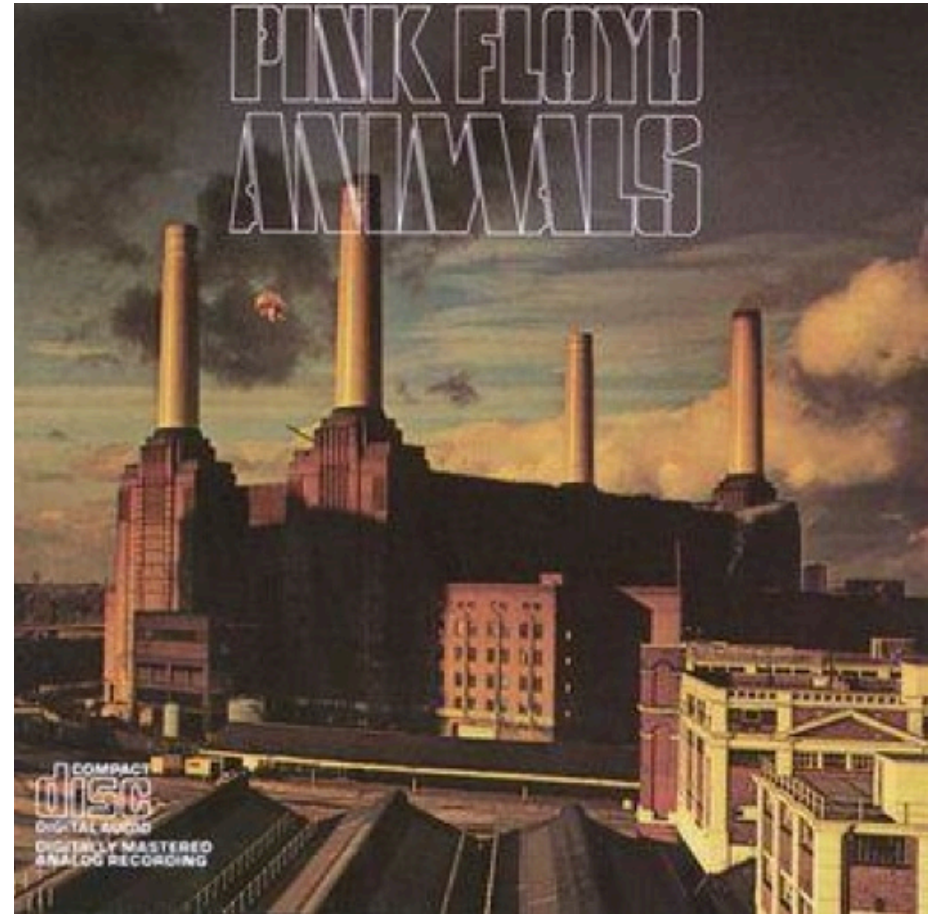

Figure 28. Pick Floyd's 'Animals' album cover, 1977 (image source: Emily Koefoed, 2011.)

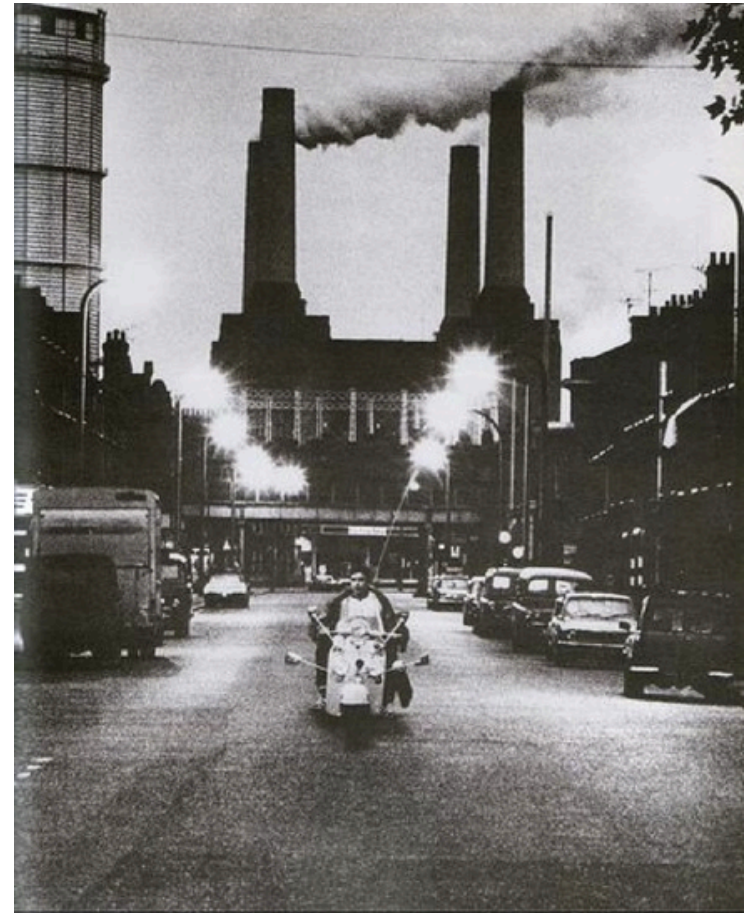

Figure 29. Booklet art for The Who's 'Quadrophenia' album, 1973 (image source: Emily Kofoed, 2011.) 
movies, music videos, and album covers during this time. In the 1970s, Battersea's energy production technology began to obsolesce, as the Oil Crisis made running the station unfeasible (Heathorn, 2013). Resultantly, the station was only used in times of peak energy need in London, and Battersea A was closed in 1975 (Heathorn, 2013). After energy production ceased at Battersea A, community members started to worry about the building's future. In an attempt to save the Art Deco building, a campaign to designate Battersea as a heritage building was started in 1978 (BSCG, n.d. a). In 1980, due to the building's architectural and historic merit, Battersea Station was awarded Grade II heritage status, meaning that it "could not be altered or demolished without government consent" (BSCG, n.d. a). Shortly after heritage designation, and as central London's last working power plant, Battersea B was decommissioned in 1983, and its generating machinery was removed that same year (GLA, 2009b). By 1984, just one year after Battersea had be decommissioned, the plant cost $£ 16$ million per year to maintain. As a result, the Central Electricity was eager to demolish or offload the property, although Battersea's heritage status would complicate the former option (Bowler \& Brimblecombe, 1991).

\section{Project Vision}

Due to its iconic status, cultural significance, and prime waterfront location, there has been notable community interest and support for Battersea's preservation over the years. However, the huge financial costs associated with redeveloping the monumental building and remediating the brownfield site on which it sits has caused Battersea's ownership to shift numerous times since it was decommissioned in 1983. As a result, the vision for Battersea's redevelopment has seen multiple iterations. Shortly before shutting down the plant, Battersea's then-owner the Central Electricity Board (CEB) had planned to demolish the station and build housing in its place. This plan, however, was stifled when Battersea was designated as a heritage building in 1980 (Heathorn, 2013). In 1983, SAVE Britain's Heritage (SAVE), an influential heritage NGO, proposed that Battersea be transformed into a massive sports complex. While this plan was supported by Wandsworth Borough Council (WBC) (the local borough in which Battersea is 
located), as well as the Greater London Council (GLC), CEB rejected the idea as the plant had not yet been fully decommissioned (Heathorn, 2013). Soon after, another proposal to transform the site into an 'academic powerhouse' was put forward, but similarly rejected by WBC (Jackson, 1984).

In light of the enormous costs of site maintenance mentioned above, the CEB was eager to redevelop Battersea, and urged Wandsworth Council to release a redevelopment brief (Heathorn, 2013). Selling the site to a private developer was seen as a way to revitalize the area without public subsidy. Preparations for the brief involved thorough consultations with local organizations and community members, and a 1984 survey found that $69 \%$ of those surveyed supported preserving the station (Heathorn, 2013). Also during this preliminary visioning phase, community consultations affirmed that the site should house a recreation facility, be publicly funded, and should not include hotels, offices or luxury housing (Heathorn, 2013). Following the Wandsworth brief in 1984, seven development proposals were submitted, including plans for a shopping centre, theme park, conference centre, incineration plant, and sports complex (Heathorn, 2013). The six redevelopment concepts were displayed in three locations throughout Wandsworth for five weeks, and community members were urged to select their favourite (Heathorn, 2013). Despite noted community dissatisfaction with the theme park development concept - 753 of 1920 survey responses listed it as their least favourite option - this proposal was chosen as the winner. It seems no coincidence that the proposal had been submitted by John Broome, an influential Conservative with strong ties to Margaret Thatcher (Heathorn, 2013). Broome formed a new company, Battersea Leisure Ltd., and submitted a formal development application to convert Battersea into an industrial heritage themed amusement park in 1985. However, community consultations revealed substantial opposition to the project (Heathorn, 2013).

Despite a plethora of complaints and criticisms, Battersea Leisure Ltd.'s proposal was accepted in 1986, and Broome acquired the Battersea site for £1.5 million in 1987 (Heathorn, 2013). Given the central location and size of the site, this was a shockingly 


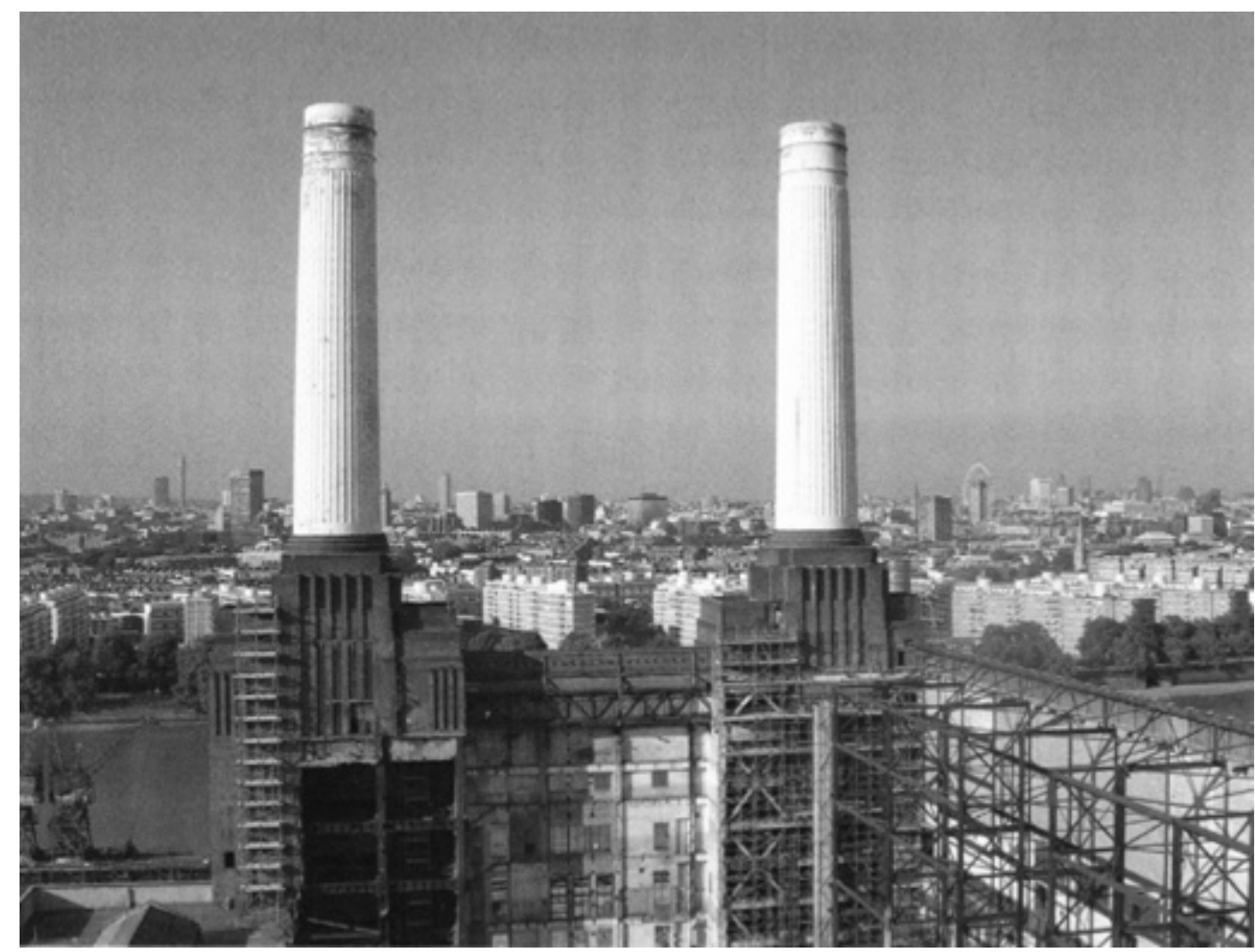

Figure 30. Battersea Station viewed from the south with west (left) wall and roof removed, 2008 (image source: Stuart Tappin in Keith Garner, 2008)

low sales figure. While critics attributed this to Broome's political connections, officials stated that the low cost reflected the preservation and remediation that would be required prior to redevelopment (Heathorn, 2013). Further, as the Greater London Council was abolished in 1986, and was only replaced by the Greater London Authority in 2000 , it has also been suggested that the lack of a city-wide authority led to the shortsighted and grossly undervalued sale of Battersea (Interview, June 16, 2015). Construction preparations started soon after Battersea was sold to Broome, and the station's internal features were stripped, while its roof and one wall were removed (Heathorn, 2013). In 1989, capital for the project ran out, and there were suspicions that Broome was letting the property fall into disrepair so that Battersea could be demolished, and the property sold for sizable profits (Heathorn, 2013). However, a new proposal for the site was submitted by Broome in 1990. In order to pay for Battersea's revitalization, this new plan included hotels and office towers (Heathorn, 2013), but the site stagnated for several years. 
It was only in 1993, when the site was acquired by Parkview International, a Hong Kong based development firm, that the Battersea project recommenced (Heathorn, 2013). Parkview International bought the site from Broome for $£ 10$ million, which included absorbing $£ 70$ million of debt from the project (Heathorn, 2013). The new owners significantly changed the project vision, proposing a mixed-use development including housing, retail and leisure facilities; their plan was approved by Wandsworth Council in 2001 (Heathorn, 2013). However, work did not recommence at Battersea, as the developers were unable to secure the massive financing required for the project (Heathorn, 2013). Throughout this period Battersea's main turbine hall remained a "roofless shell" (GLA, 2009b, p. 189), and exposure to the elements caused continuous damage to the building (Hansen, 2005). Despite fierce community opposition, and independent engineering reports assuring the structural integrity of Battersea's iconic chimneys (Interview, June 16, 2015), Parkview International feared the liability associated with the rapidly degrading smokestacks. Thus, in 2005 , consent was given to demolish and rebuild Battersea's iconic heritage-protected chimneys (Heathorn, 2013).

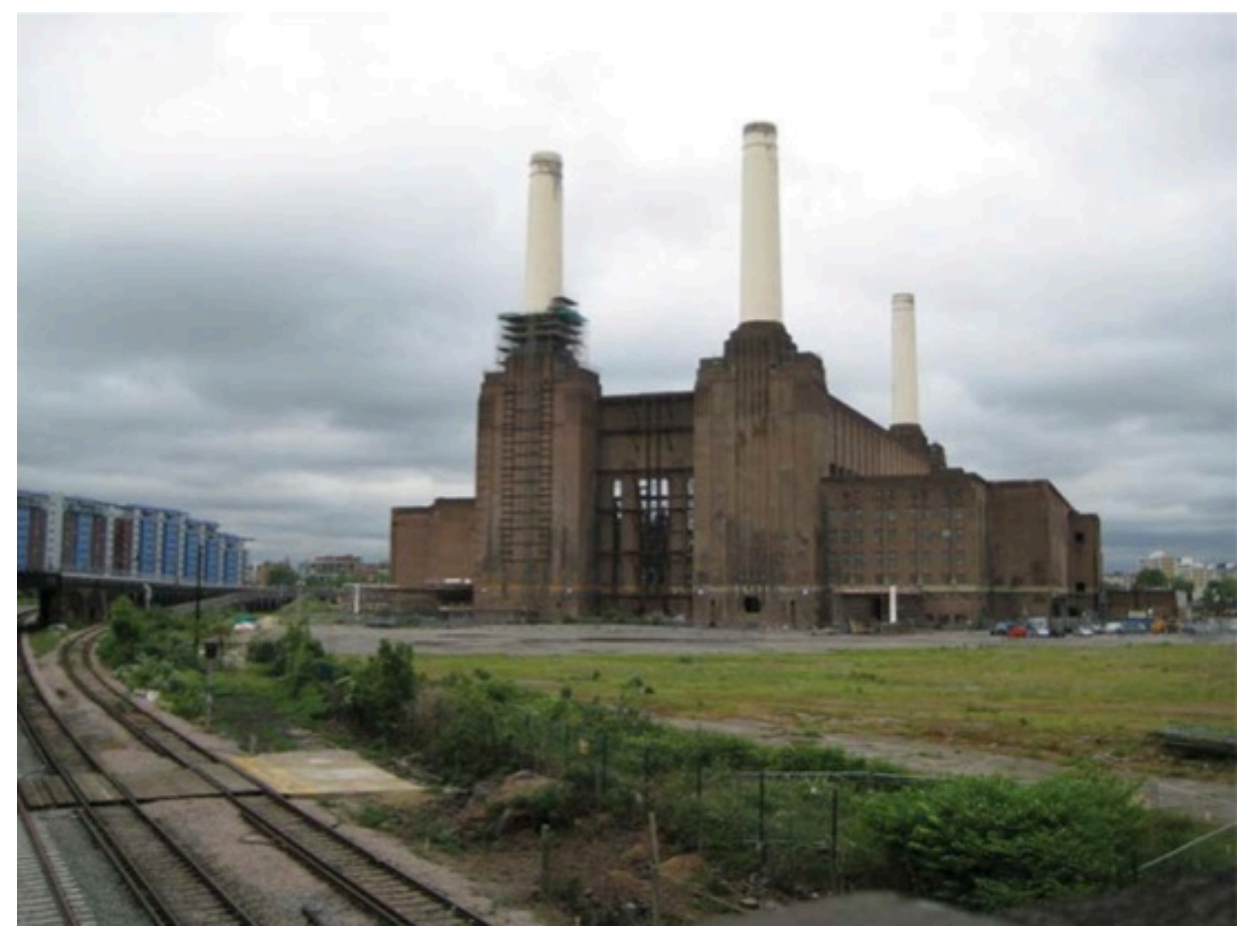

Figure 31. Battersea Station viewed from the south, 2008 (image source: Nigel Cox, 2008) 


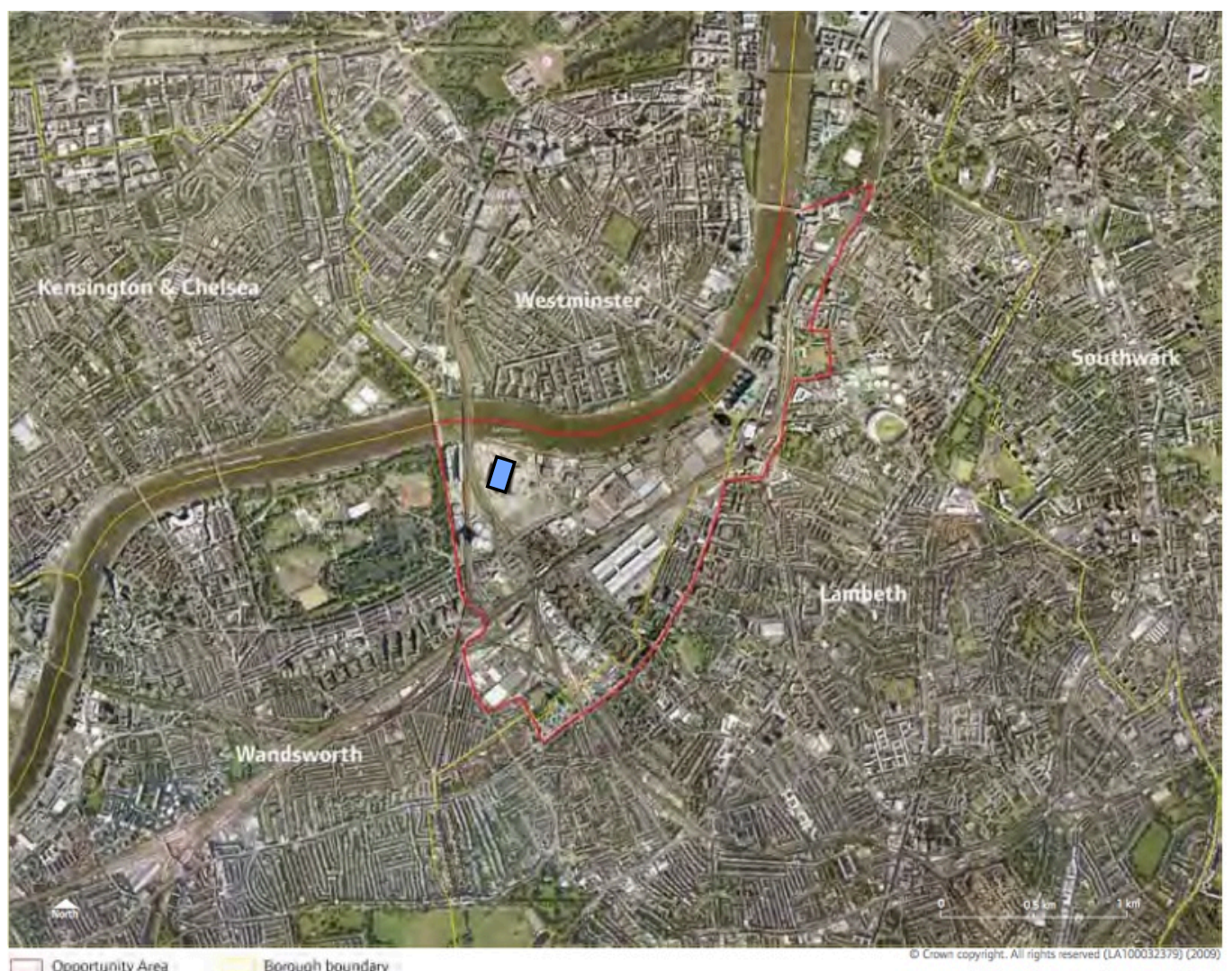

Figure 32. The VNEB Opportunity Area (outlined in red) in context, with Battersea Station shown in blue, and borough boundaries in yellow (image source: Greater London Authority, 2012, edited by author)

However, Parkview's attempts to redevelop Battersea also proved futile, and they sold the site to Irish development company Real Estate Opportunities (REO), a subsidiary of Treasury Holdings, for $£ 400$ million in 2006 (Heathorn, 2013). In 2007, while REO was developing its plans for Battersea, Battersea's heritage designation was raised to $\mathrm{II}^{*}$, in an attempt to further protect the building from an uncertain development future (GLA, 2009b). Further, the entire Vauxhall Nine Elms Battersea (VNEB) area on London's South Bank was designated as an Opportunity Area in the 2009 London Plan (the City's Official Plan), and Battersea itself was isolated as a potential new Central Activities Zone, slated for mixed-use intensification (GLA, 2012). The 2009 London Plan also mandated a triple-bottom-line sustainability approach to all development in the area (GLA, 2012). Consistent with the new London Plan, REO's initial vision for Battersea included several sustainability features, including a sustainable energy centre and a privately-funded London Underground extension into the area, as well as substantial residential, office and retail development (Real Estate Opportunities [REO], 2009). REO positioned the huge redevelopment project as a "catalyst for regeneration and socio- 
economic enhancement" of the area (REO, 2009, p. 2). However, Battersea had been purchased by REO with funds from the Bank of Ireland, and following Ireland's post-2008 economic downturn, REO was forced to sell the property in 2012 (Heathorn, 2013). Several offers came in, including one from Chelsea Football club that would see Battersea reused as a stadium (Heathorn, 2013).

Amid uncertainty about Battersea's future, the Greater London Authority released a Planning Framework for the VNEB Opportunity Area (OA) in 2012. Consistent with the 2009 London Plan and Wandsworth Council's 2010 Core Strategy, the framework established VNEB as the largest remaining development opportunity in central London, stressed sustainability, and mandated high-density mixed-use development, public realm improvements such as green space and social infrastructure including schools, libraries, and health centres, and affordable housing (GLA, 2009b). The plan also reiterated the importance of extending public transit into the area, including the Northern Line tube extension, and proposed tackling climate change through a district heating network to serve the whole OA, flood mitigation measures, and green building and infrastructure (GLA, 2009b).

In December, 2012, soon after the VNEB Planning Framework was released, Battersea was bought by a group of Malaysian investors including development firm SP Setia and plantation giant Sime Darby. With funding from Malaysian government pension funds (Interview, June 16, 2015), the company had access to deep financing, and soon after started an $£ 8$ billion revitalization of the area under the newly formed Battersea Power Station Development Company (BPSDC) (Kollewe \& Osborne, 2014). Consistent with the vision put forth in the City's VNEB Planning Framework, the current vision for Battersea is to transform the 15-hectare site into a mixed-use neighbourhood, that includes residential and commercial uses, restoration of the historic Battersea Station (including demolishing and rebuilding its four chimneys), an extension of the London Underground Northern Line (Heathorn, 2013), and a district heating network (BPSDC, 2014b). Given the scale of redevelopment, the project will progress in multiple phases, and take over a decade to complete (BPSDC, 2014b). Since acquiring the property in 


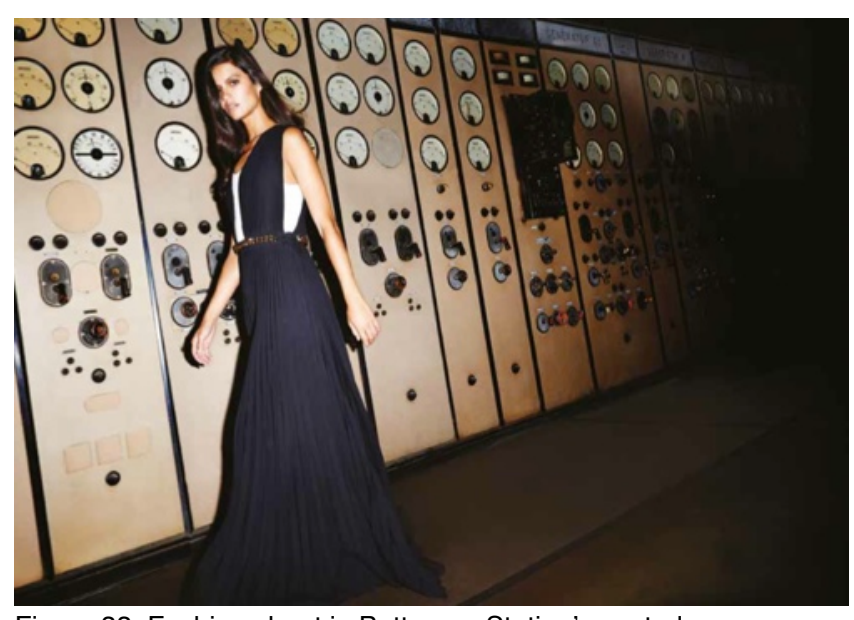

Figure 33. Fashion shoot in Battersea Station's control room (image source: Andrew Woffinden/BPSDC, 2014)

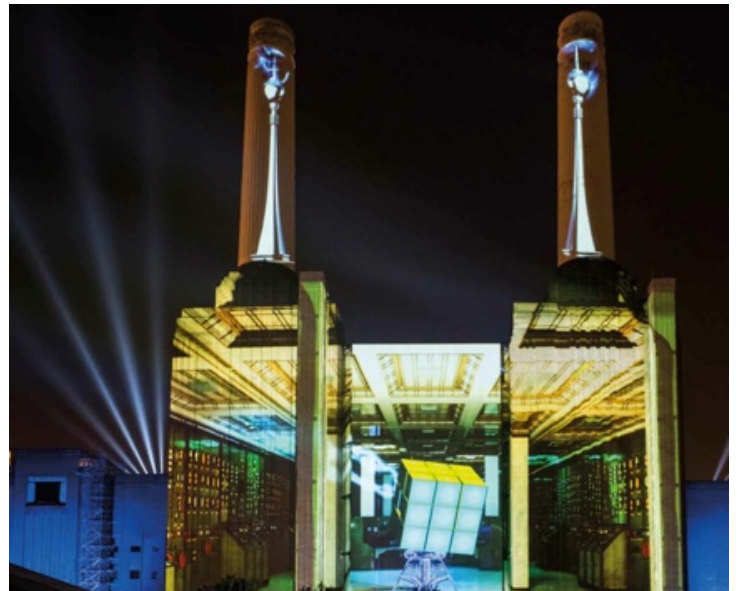

Figure 34. Light show at Battersea Station (image source: BPSDC, 2014)

2012, BPSDC has promoted Battersea's redevelopment by hosting several 'pop-up' arts and cultural events at the power station, including high-profile concerts, light shows and even a fashion shoot.

As the decommissioning of Battersea coincided with a period of economic decline and deprivation in Wandsworth, any new development is required to take the needs of the existing disadvantaged community into account (Heathorn, 2013). While the new development will cater to affluent tenants, many of the redevelopment's features, such as the Underground extension, also have the potential to benefit current residents, although concerns persist regarding segregation between new and existing residents (Interview, June 16, 2015). While many opponents of the current redevelopment criticize it for neglecting the needs of Wandsworth's existing community (Interview, June 16, 2015), Wandsworth Council and the developer appear to have incorporated numerous sustainability elements into development plans. These are outlined in Positive Energy (BPSDC, 2014b), a promotional document released by BPSDC outlining sustainability features, benchmarks and goals of the Battersea project. 


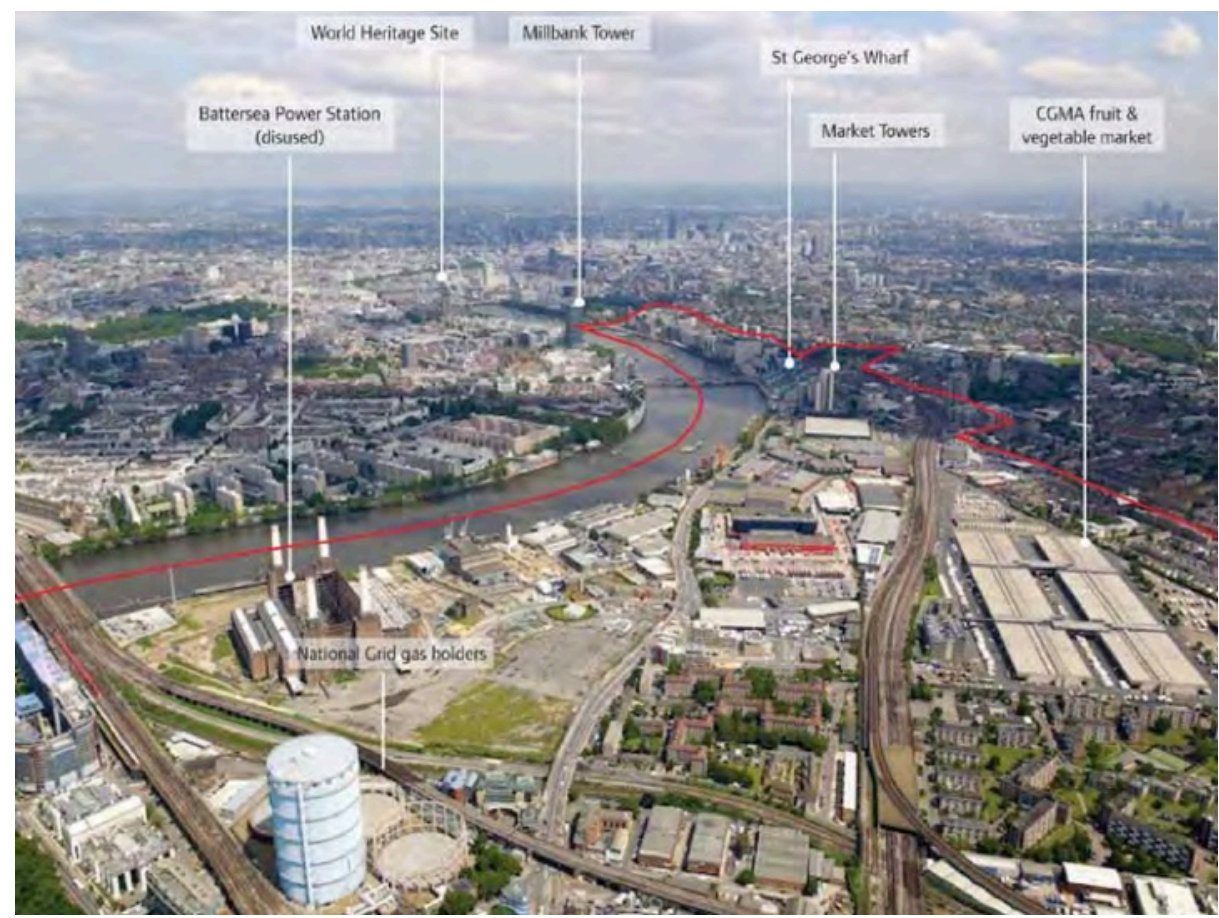

Figure 35. Battersea Station in context, pre-redevelopment (with VNEB Opportunity Area outlined in red) (image source: Greater London Authority, 2012)

\section{Projects Characteristics and Development}

\section{Location and Site Context}

The 15.8 hectare Battersea Station property is located on the western edge of London's South Bank, at 28, 88 and 188 Kirtling Street and 2 Battersea Park Road (REO, 2009). The site has 450m frontage on the River Thames (BPSDC, 2014c), is within the larger Nine Elms area, and is classified as a part of London's Central Activities Zone. As Battersea lies across the river from the Palace of Westminster, a World Heritage Site, stringent height restrictions are placed on development in order to preserve view corridors to the palace (GLA, 2009b). This means that development at Battersea cannot surpass $60-70 \mathrm{~m}$, meaning that new buildings will not surpass the height of Battersea Station's iconic chimneys (GLA, 2009b). Battersea's location on the banks of the Thames also puts the site at risk of flooding. A flood risk assessment for the site classified it as Flood Zone 3a, meaning that it has a 1 in 100 or greater annual probability of flooding, and a 1 in 200 or greater probability of flooding from the sea in any given year (GLA, 2009b). However, the area is protected by the Thames barriers 
and River Walls (GLA, 2009b), and all development must place habitable floors above the 1000-year flood level of $0.5 \mathrm{~m}$ in order to mitigate flood risk (GLA, 2009a).

While the area surrounding Battersea was largely industrial until the 21st century, it has seen rapid change since being identified as an Opportunity Area by the Greater London Authority in 2009. Thus, VNEB is currently undergoing a transformation into a mixeduse neighbourhood. Stewarts Road industrial area, to the south of Battersea, will be the only area in VNEB retained as strategic industrial land (SIL), meaning that intensification of employment uses will be encouraged (GLA, 2009b). In spite of the area's revitalization, remnants of its industrial past remain, in the form of major industrial infrastructure, roads and railways that sever and fragment the landscape. Battersea lies adjacent to two safeguarded wharves on the Thames, Kirtling Wharf, an operational aggregates wharf, and Cringle Dock, an operational waste site (GLA, 2009b). The Cringle Dock solid waste transfer station is also Battersea's immediate neighbour to the east. Additionally, although Battersea Park lies just to the west of the power station, the two sites are highly segregated due to the elevated rail lines running between them (GLA, 2009b). Battersea is also close to New Covent Garden Market, though connection between the sites is hampered by major roadways. Further, as a former industrial site, Battersea is underserved by public transportation (GLA, 2009b). While the aim of large-scale development of the entire VNEB area is to remove infrastructure barriers and incorporate multi-modal transportation links with the rest of the city, in its current state of development, many of these challenges remain.

As previously mentioned, Wandsworth's current residents suffer from income, health, employment, education and skills deprivation, which has taken a toll on the area's image and caused stigmatization of the neighbourhood (GLA, 2009b).

\section{The Development}

The Battersea site will be developed in multiple phases, and take over a decade to complete (BPSDC, 2014b). With its unprecedented scale and £8 billion investment, 


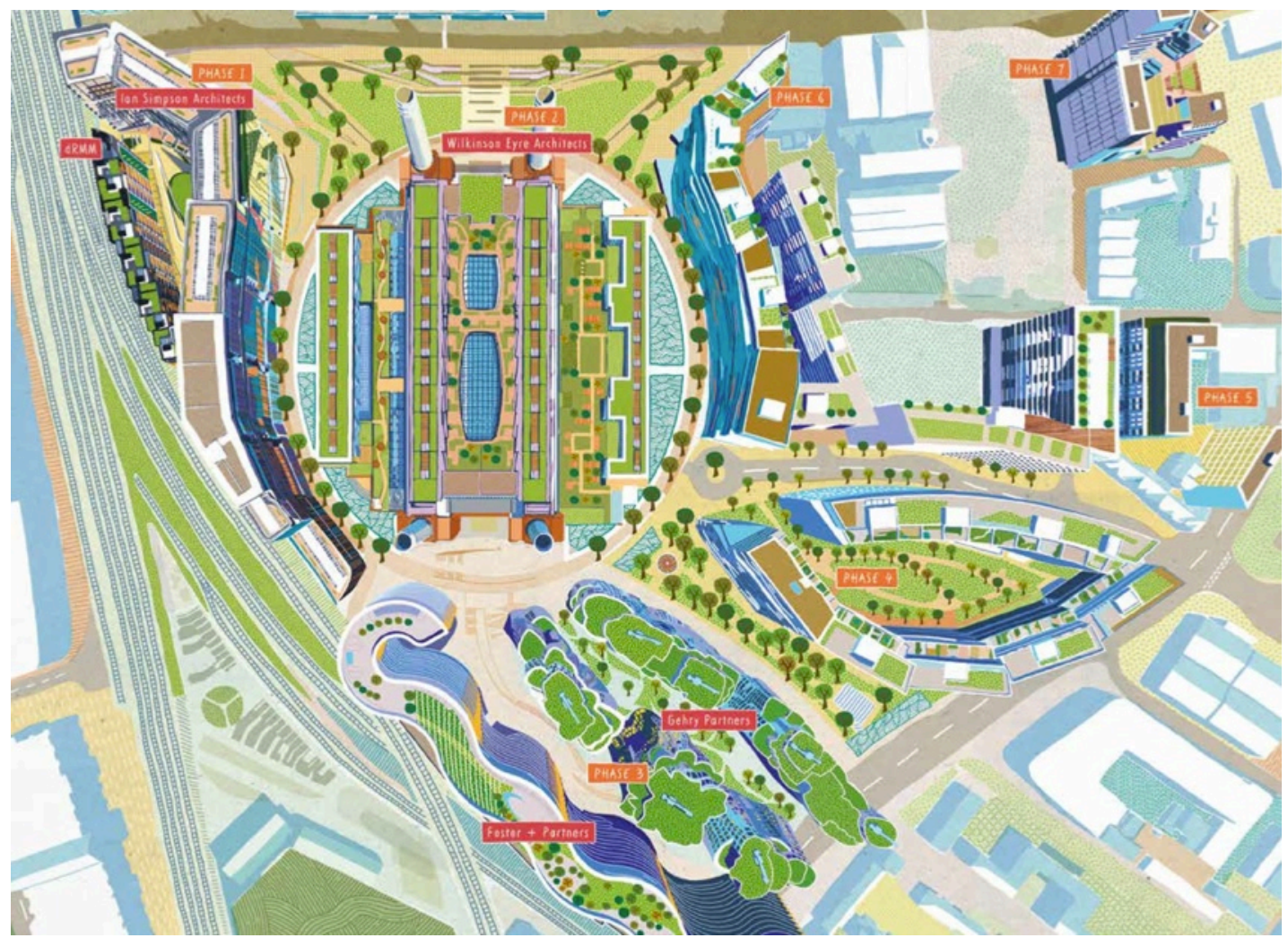

Figure 36. Illustration of the Battersea redevelopment, showing development phases (image source: Peter Reynolds/BPSDC, 2014)

Battersea's redevelopment is London's largest regeneration project (Denison, 2012). In its entirety, the development will create 4,000 new homes and 8 million square feet of mixed uses in 16 new buildings built around the historic power station, and will also include the adaptive reuse of Battersea Station itself (Denison, 2012). Given Battersea's location in a view corridor to Westminster Palace, all buildings will be between 8 and 18 storeys high (Denison, 2012). The first phase of Battersea's development will involve building two mixed-use buildings to the west of Battersea Station; the buildings will contribute 1 million square feet of floor area, and will contain mainly housing, with a variety of ground-floor uses, including retail, office, restaurant and leisure (BPSDC, 2014c). Phase l's expected completion date is 2016 (BPSDC, 2014c).

The second phase of the project will involve the adaptive reuse of Battersea Station itself into a 'creative quarter'. The grade $\mathrm{I}^{*}$ heritage power station has a footprint of roughly 6 acres, and measures 525 feet long, 525 feet wide and 344 feet tall (Hansen, 


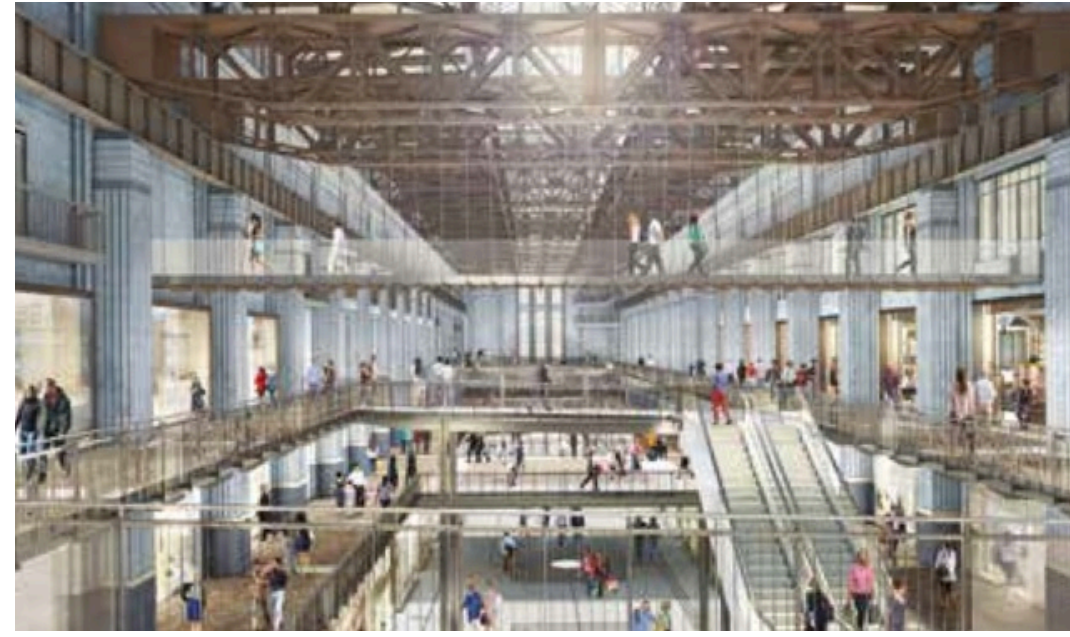

Figure 37. Rendering of Battersea Station's commercial interior, after redevelopment (image source: BPSDC, 2014)

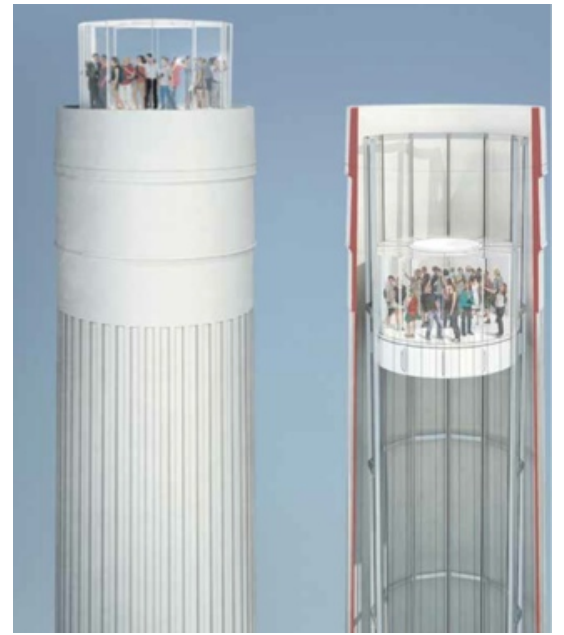

Figure 38. Elevator in Battersea Station chimney (image source: BPSDC, 2014)

2005). Battersea Station contains two massive turbine halls, A and B, located in the station's lower subsidiary wings, while the large central structure once housed multiple levels of electrical transformers (Jackson, 1984). Turbine Hall A and the station's Art Deco control room are of particular historical and architectural value, and will be preserved through the building's transformation. Further, the large fluted chimneys will be deconstructed and rebuilt, owing to extensive damage and liability issues, and plans are underway to transform the northeastern smokestack into an elevator and viewing platform accessible to paying visitors (BPSDC, 2014c). The power station's vast interior space will also house cultural, educational, retail, creative office and luxury residential space (BPSDC, 2014c).

Phase III of the project will involve the site just south of the power station, which will serve as the main gateway into the development, and will connect the site to the new NLE Battersea tube station (BPSDC, 2014c). Phase III will provide 1,310 residential units, including 103 affordable homes, a 167 room hotel (BPSDC, 2014a), two levels of retail/restaurant space, a community hub, and 1,349 parking spaces to serve the entire development (BPSDC, 2014a). Phases IV-VII will involve building several mixed-use buildings to the east of the power station, with residential units above commercial space on the lower floors (BPSDC, 2014c). The development will also include several public realm improvements, including the creation of a new main street called 'Electric Boulevard' along Battersea Park Road, 6 acres of landscaped open space along river 


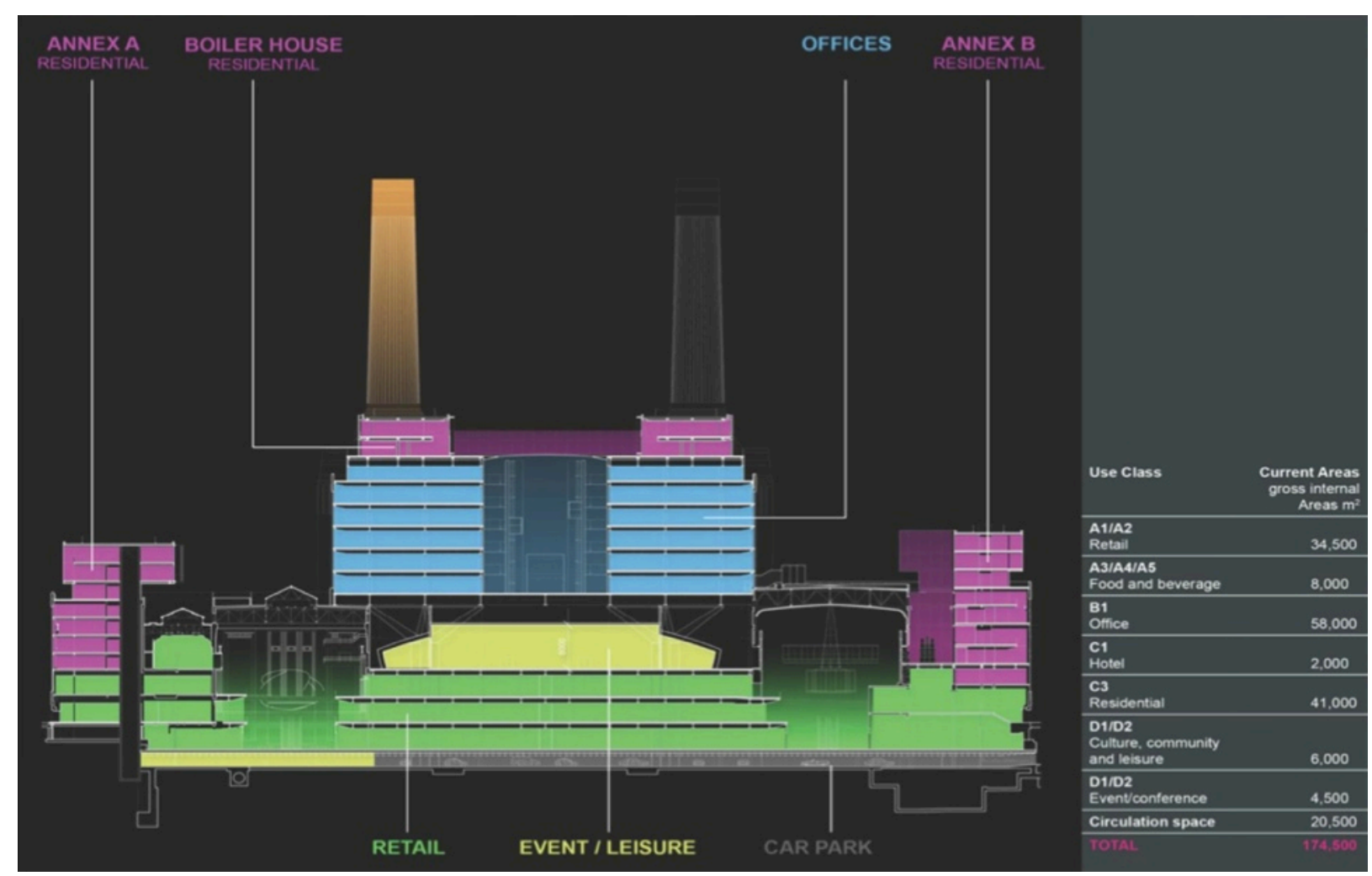

Figure 39. Proposed interior uses for Battersea Station after redevelopment (image source: BPSDC, 2014)

frontage, over 5 hectares of rooftop gardens (Denison, 2012), several parks and public plazas, and multiple pedestrian linkages throughout the area (BPSDC, 2014a).

The desirability of Battersea Station's redevelopment was highlighted when flats went on sale in January $2013^{4}$, and $75 \%$, or $£ 600$ million of flats were immediately reserved (Heathorn, 2013). Further, nearly all remaining units were bought within 5 days.

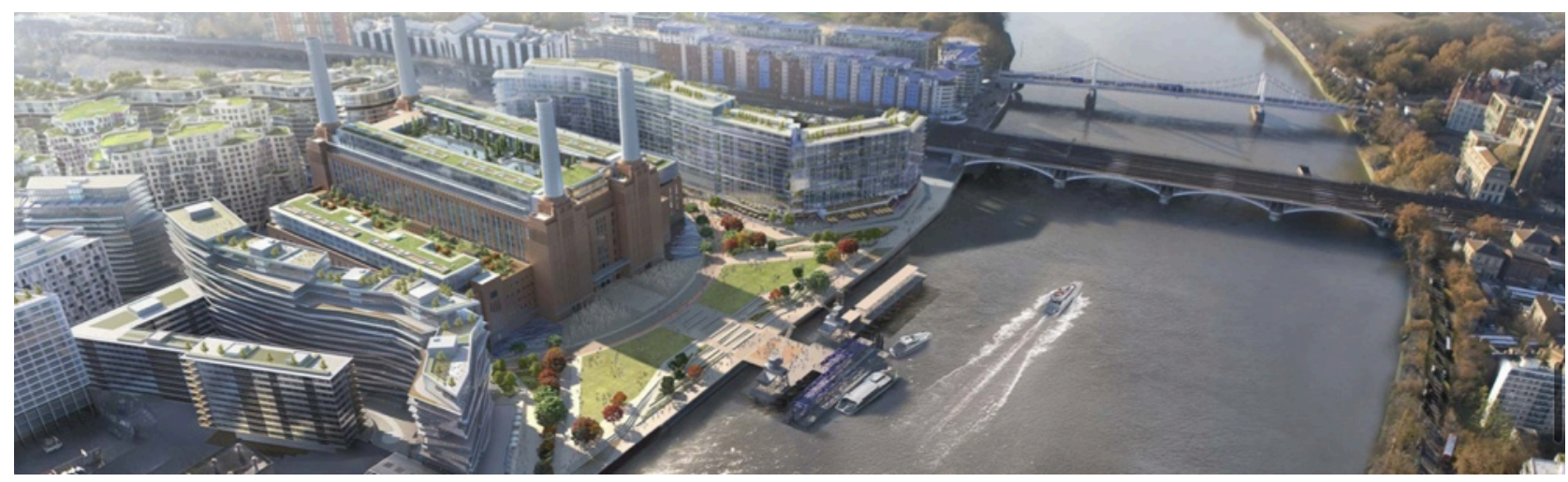

Figure 40. Rendering of the Battersea development (image source: BPSDC, 2014)

${ }^{4}$ All units are sold based on 999-year leasehold. 


\section{Sustainability Features}

Given the Greater London Authority's focus on sustainability and sustainable development, Battersea's current development plan includes multiple sustainability features, benchmarks and goals. As previously mentioned, the development's focus on sustainability is asserted and outlined through BPSDC's corporate sustainability plan, Positive Energy (BPSDC, 2014b). While Positive Energy lays out BPSDC's current commitment to sustainability, it is also intended to evolve as a report of progress for the decade-long development (BPSDC, 2014b), and to serve as a means of knowledge and information sharing about the project's sustainability successes and barriers (Interview, July 20, 2015a). Positive Energy takes a triple-bottom-line approach to sustainability, and thus outlines initiatives to improve and maintain the environmental, economic and social character of the area.

The redevelopment project includes several environmental improvement strategies, the most notable of which is the creation of an on-site energy centre and district heating network. This new state-of-the-art power generator will make Battersea the largest zerocarbon development in Britain, and possibly the world (Denison, 2012). Some of Battersea's unique industrial features will be reused to accommodate the new 50,000square-foot energy centre, as it will be housed within Battersea's enormous coal bunkers (Interview, June 19, 2015), and will use two of the plant's chimneys for vapour exhaust (Interview, July 20, 2015b). The district energy centre will provide heating, hot water, and cooling for $100 \%$ of the residential, retail and office buildings in the development, and will save at least 6,000 tonnes of CO2 per year (BPSDC, 2014b). However, planning agreements between BPSDC and the City do not specify what will be used to power the energy centre (Interview, July 20, 2015b). The development team has stated that ambiguity and flexibility were required in planning documents, as this will allow advances in energy production technology to be explored and incorporated over the project's extended timeline (Interview, July 20, 2015b). Had the developer specified the source of energy from the outset, they would be locked-in to technology that may be antiquated by the time development wraps up in 2024. Currently, BPSDC is 
investigating using the Thames as a source of energy, via innovative surface water source heat pump (SWSHP) technology. This type of system would also make use of the many pipes and tunnels that once connected Battersea's boilers with the river for cooling purposes (Interview, July 20, 2015b). However, the ambiguity of energy production has also been questioned by some community members, who suspect that development partner Sime Darby, a Malaysian palm plantation giant, could use unsustainable Palm Oil Mill Effluent (POME) as fuel (Interview, June 16, 2015).

Other environmental initiatives at Battersea include protection and remediation of the site's flora and fauna, including insects, black redstarts and peregrine falcons (both Schedule I protected species), as well as on-site wildflower planting (BPSDC, 2014b). Further, the development includes 25,000 square metres of green, brown and bio-roof, as well as 20 acres of open space (BPSDC, 2014b). Nearby protected wharves on the Thames will also be used to transport excavated material, which will save 750 return truck loads, and $95 \%$ of construction waste from Phase I will be diverted from landfill (BPSDC, 2014b). Further, buildings will be constructed to BREEAM ${ }^{5}$ standards, while the historic power station will adhere to BREEAM domestic refurbishment assessment program (Interview, July 22, 2015).

Although the remediation of industrial contaminants from soil and groundwater should be an important aspect of Battersea's sustainability plan, Positive Energy does not mention this aspect of the development at all. In fact, specifics as to on-site contaminants and remediation plans are often deeply buried in early planning reports and appendices, perhaps because of the stigmatization that such information might impart on the development project. While asbestos was reportedly found in the walls and ceiling of Battersea's Art Deco control room (Hansen, 2005), this was removed well before redevelopment started. With that said, a ground condition survey conducted by Treasury Holdings in 2009 revealed several soil samples with levels of arsenic, cadmium, lead and nickel above the residential threshold, while other samples revealed

\footnotetext{
${ }^{5}$ BREEAM is the Building Research Establishment Environmental Assessment Methodology, which functions much like LEED.
} 
Polyciclic Aromatic Hydrocarbons (PAHs) and Extractable Petroleum Hydrocarbons (EPHs) in concentrations above those allowed in commercial/industrial land uses (GLA, 2009a). Hydrocarbon odours were also detected in other soil surveys around the Battersea site (GLA, 2009a). While little public information could be located on site remediation, interviews revealed that additional asbestos deposits had been found through construction, while soil remediation was being conducted on-site via a 'soil hospital' (Interview, July 22, 2015). Further, it was noted that Britain's strict regulatory environment and landfill tax, which charges developers $£ 80$ per ton of non-hazardous material sent to landfill (and much more for hazardous material) helped ensure that remediation was done on-site (Interview, July 22, 2015).

Incorporating multiple modes of transportation into the development area is also a significant sustainability feature at Battersea. In addition to 8,000 new bike spaces, a bikeshare program (Interview, June 19, 2015), $2.25 \mathrm{~km}$ of new cycle/pedestrian routes and $1 \mathrm{~km}$ of dedicated pedestrian route in the development area, $20 \%$ of retail and $10 \%$

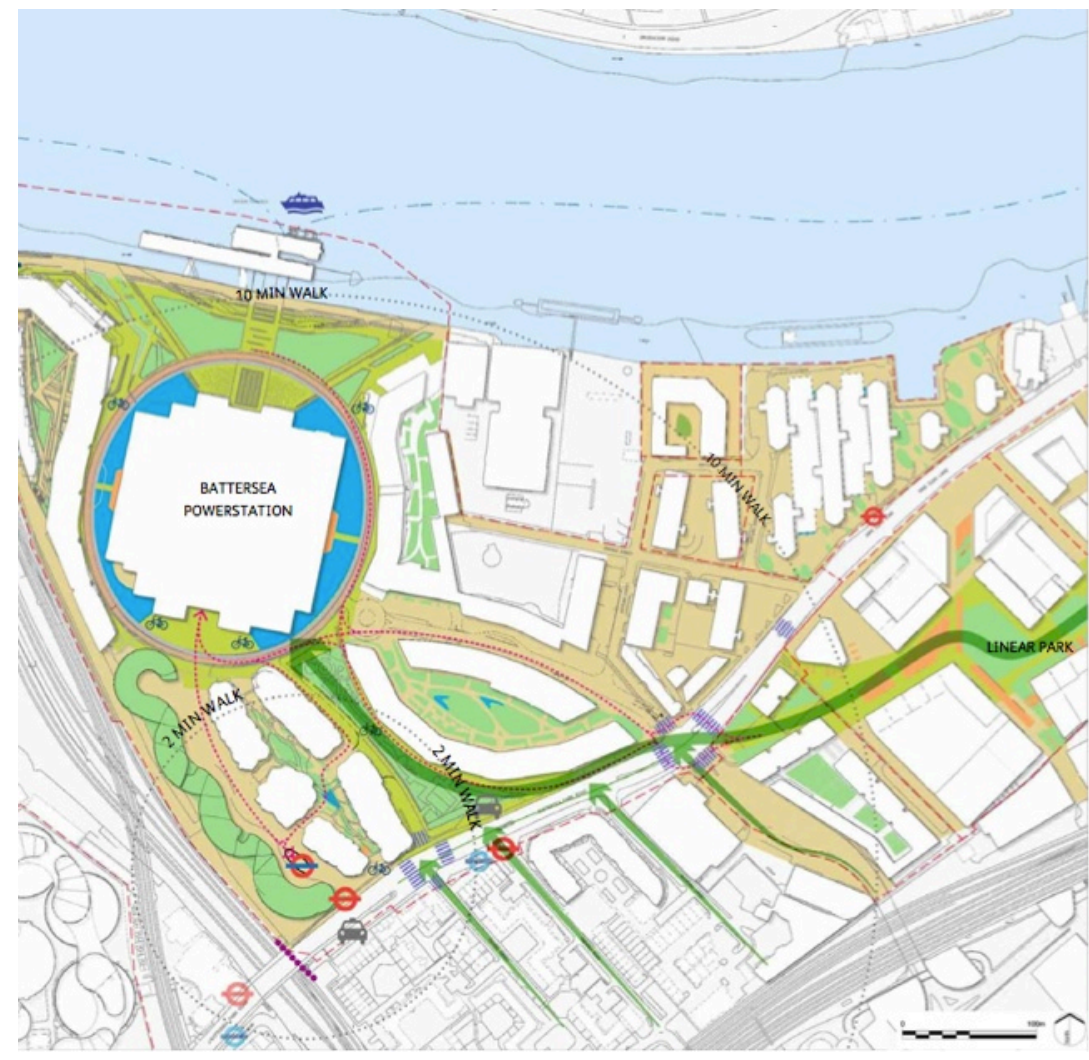


of residential parking spaces will include electrical vehicle charging points (BPSDC, 2014b). Further, several public transportation initiatives are central to the development, including a new riverbus and extended bus service in the area (BPSDC, 2014b). Most importantly, the development will benefit from the Northern Line Extension (NLE), which will include two new tube stations on the south bank, Nine Elms and Battersea (Denison, 2012); the NLE is London's first part-privately funded tube extension (BPSDC, 2014b). While the NLE provides environmental benefits, it will also ensure the economic viability of the area. According to Transport for London, the NLE allows for greater development density in the wider VNEB area, and will thus contribute billions of pounds to the City and local economy (BPSDC, 2014b). There are also plans to increase general connectivity throughout the VNEB area, including the construction of a new pedestrian/cycling bridge over the Thames east of the Battersea site (GLA, 2012).

As Battersea's redevelopment involves revitalizing formerly derelict industrial lands, the project will also impart considerable economic effects. Battersea's construction phase alone will contribute $£ 11$ million of additional income tax per year to the Central Government and £2 billion to the British economy, while the completed project is expected to contribute $£ 153$ million in annual income taxes from on-site businesses (BPSDC, 2014b). The development will also contribute £3 million per year to the Borough of Wandsworth through council tax, and $£ 20$ million annually via business rates (BPSDC, 2014b). The project will also create 20,000 construction jobs over the course of the project (Denison, 2012), and 17,000 direct and indirect jobs once complete (BPSDC, 2014b). Providing jobs and skills training to existing residents is also an aim of the project. The development site will be home to Battersea Academy of Skills and Enterprise (BASE), aimed at training locals for a variety of employment positions, and the first phase of construction will involve 86 local apprentices (BPSDC, 2014b).

While these initiatives support economic and social sustainability, other measures are being taken to ensure that disadvantaged local community members also benefits from the development. For example, the development includes 20 acres of open space (BPSDC, 2014b), although how much of this will be publicly accessible is not stated. 
There are also plans to build social infrastructure such as a new health centre (Interview, June 19, 2015), police station and children's play area within the development. Further, a 2-storey community hub is being built on-site; while this was originally intended to house a library, the maintenance fees required from the local government made this feature untenable (Interview, June 19, 2015). Further, the costly conservation and restoration of Battersea Station itself is a substantial community benefit. The developer has also hosted numerous public consultations and estimates that they have consulted with nearly 100,000 people over 32 days of formal community participation (BPSDC, 2014b). However, community members interviewed for this research project countered that many of the consultation events are invite-only, not open to the general public, and require signing non-disclose and good-behaviour agreements (Interview, June 16, 2015).

While Positive Energy boasts about providing a total 517 affordable housing units within the development, this quota is well below the minimum of $33 \%$ affordable units mandated for all residential development in Wandsworth's Core Strategy (GLA, 2012). The local government and developer have explained this discrepancy by stating a need to prioritize infrastructure funding in the area, including the NLE, which they deem necessary to the development's success; this is in spite of the London Plan outlining affordable housing as a strategic priority for the City (GLA, 2012). As a result, the development will be an affluent oasis in a community known for its high levels of deprivation, which may cause significant tension, conflict, and segregation between new and existing residents.

Despite these numerous sustainability claims and plans, it is too early in the development process to gauge how Battersea is measuring up. Hopefully, the City and the development team will accurately and transparently measure and monitor the project's progress and achievement, so a fuller picture of the successes and failures of the various sustainability tools and features can be developed upon project completion. 


\section{Project Funding}

While the development of the buildings and site remediation will be entirely privately funded by a consortium of Malaysian investors, the major public contribution to the development is the myriad infrastructure and transportation improvements that are pivotal to the project's success. Most notable of these infrastructure investments is the NLE, which involves constructing two additional tube stations that will serve VNEB at a cost of $£ 1$ billion, and will drive significant development in the area (Porter, 2014). A Development Infrastructure Funding Study undertaken in 2010 explored the levels of infrastructure and public transportation required to support the area's new high-density development, and determined that the project would not be feasible without significant infrastructure improvements in the area, including the NLE (GLA, 2012). Thus, in 2010, the Nine Elms Vauxhall Partnership (NEVP) was formed between Wandsworth and Lambeth Councils (Lambeth is Wandsworth's neighbour to the east) the Greater London Authority, the Mayor, Transport for London (TfL), and the area's major developers and land owners. The Partnership is responsible for managing the area's billion-pound infrastructure package (NEVP, n.d.).

The authorities claim that the NLE will be entirely funded by the development that it enables, via value-capture tools such as Community Infrastructure Levies (CILs), S. 106 contributions (development tariffs) and incremental business rates (Sell, 2014). As one of the area's major developers, BPSDC has already agreed to contribute over £200 million to the NLE via S. 106 contributions (BPSDC, 2014b). However, front-end financing for the NLE project will come via Tax Increment Financing (TIF), a relatively new and controversial value-capture tool in the UK. In order to gain access to financing, the GLA will form an Enterprise Zone (EZ) in the VNEB Opportunity Area starting in 2016, for a period of 25 years (TfL, 2014). The GLA will then take out a $£ 1$ billion loan for the project with a repayment guarantee from the UK Government (Pincent Masons, 2012), to be repaid with future growth in business rates revenues, as well as S. 106 and CIL contributions from the EZ (Sell, 2014). 


\section{Lessons Learned: Project Enablers and Barriers}

Interviews with several key stakeholders in Battersea's redevelopment, including public officials, community representative, sustainability consultants and members of the development team highlighted some common themes regarding the project's key enablers and barriers. While this massive redevelopment is in its nascent stages, with Phase I to be finished in 2016 and the entire project aiming for completion in 2024, research participants nevertheless shared valuable insight on how this project was able to gain momentum after multiple false starts over nearly 30 years. Consistent with brownfield redevelopment literature (Lange \& McNeil, 2004), interviews also outlined the nebulous definition of project 'success' at Battersea, as interviewees had divergent opinions about the project's merit. Further, there was a notable focus on the economic success of the Battersea project from the development team, sustainability consultants and city officials, a concept opposed by community groups, yet also revealed in previous brownfields research (Howland, 2007).

One of the key enablers of the project was a concerted effort from the private and public sectors, including Wandsworth Council, the Greater London Authority, the UK Central Government, and the development team (Tibby, McDougall \& Porter, 2010). The particular importance of political alignment was stressed by one interviewee, who pointed out that Wandsworth is a conservative, pro-development borough, which has been historically supportive of Battersea's revitalization and economic development (Interview, June 19, 2015). Further, the same participant noted that the NLE was agreed to during the term of a conservative Mayor in London, while the $£ 1$ billion TIF loan for the NLE was guaranteed by a Conservative Central Government. Having a strong group of stakeholders and developers invested in the VNEB area as a whole, such as the US Embassy development project in neighbouring Nine Elms, was also acknowledged as creating additional legitimacy and support for Battersea's transformation (Interview, June 19, 2015). 
Given the unprecedented scale of the Battersea project, it was also necessary to have a development team with access to huge amounts of up-front funding, as well as development and financing expertise (Interview, June 19, 2015). Interviewees noted that getting the Battersea redevelopment off the ground required a perfect alignment of planning, market conditions and funding (Interview, July 20, 2015a), and the high density of development was raised as a key factor in ensuring project feasibility. As the current development consortium includes the Malaysian Employees Provident Fund, one of the largest sovereign pension funds in the world (BPSDC, n.d.), their immense access to capital also made the project tenable. As evident in Battersea's multiple failed development attempts due to improper building mix and inability to secure adequate financing, these are undoubtedly key factors in the project's success this time around. To date, the Battersea redevelopment is the largest malaysian foreign investment ever made (Interview, June 19, 2015).

The project's massive scale, and location in former industrial lands lacking significant infrastructure, transportation service and connectivity with the rest of London was also a significant barrier to the project. However, this challenge was surmounted with the creation of an integrated transport and land use strategy for the area that focussed substantially on infrastructure and transportation improvements. It was noted by an interviewee that it was only when the development project was coupled with the NLE that it became feasible (Interview, June 19, 2015). Many interviewees also noted that the scale of development at Battersea allowed innovative and broad sustainability measures to be explored and implemented in the project. This is particularly relevant for major undertakings such as the NLE and the district heating network. Further, the current focus on sustainable development in the UK, and the existence of supporting legislation and policies, was stressed as pivotal to achieving sustainability at Battersea.

Another important enabler of the project's success is that it involves an iconic building, Battersea Station, which is both locally and internationally recognized and valued due to its strong presence in British culture and media (Interview, June 19, 2015). The Grade $\mathrm{II}^{\star}$ heritage building is a critical part of the area's redevelopment, as it contributes 
substantially to the image and 'brand' of the development, and adds value and prestige to real estate in the vicinity, increasing project viability. The power station's recognizability and brand power is attested to in BPSDC's logo, which prominently features Battersea's silhouette. This newly cultivated image and brand for the area is particularly important in Wandsworth, as the area has typically been stigmatized due to the Borough's high levels of deprivation. Notably, Wandsworth Borough's logo also features Battersea Station.

While the current developer has been able to overcome many of the barriers that have continually halted development at Battersea for the past three decades, some persistent impediments to project feasibility and success were raised by research participants. The first barrier noted was the project's extended timeline. As the project involves multiple phases spanning over a decade, this provides a salient obstacle to investors trying to minimize risk and ensure timely profits (Interview, June 19, 2015). Another barrier to the development has been persisting industrial infrastructure that poses challenges to the site, and fragments the landscape. These barriers include an elevated rail corridor that runs directly to the west of Battersea, and the Cringle Dock solid waste transfer station, Battersea's immediate neighbour to the east. Understandably, these negative features of the landscape are not touched on in any BPSDC promotional materials, although interviews revealed that measures are being undertaken to ensure these industrial remnants do not affect the development. For example, windows and balconies of buildings surrounding Cringle Dock have been carefully planned to open or face away from the waste station (Interview, July 20, 2015a).

Further, community members have stated that, contrary to claims from the developer, public participation in Battersea's redevelopment has been largely tokenistic (Interview, June 16, 2015). The developer's commitment to social and environmental sustainability has also been questioned, as key community benefits such as affordable housing, improved transit for all Wandsworth residents, and maintaining inclusive public access to the historic power station have not been adequately addressed (Interview, June 16, 2015). The neglect of these features has been attributed to the local authority's limited 
manpower and expertise, as well as to the developer's lack of personal interest in and connection with the local community (Interview, June 16, 2015).

The historic power station itself, although cited as one of the development's greatest assets in terms of banding and identity, was also raised as adding significant complexity to the project. Several interviewees mentioned the difficulty of refurbishing the $1920 \mathrm{~s}$ structure to meet BREEAM assessment criteria, while refurbishing the power station, including rebuilding the station's four chimneys using original techniques and materials, was also cited as an enormous project expense (Interview, July 22, 2015). Further, community interest in the power station was also noted by some members of the development team as complicating the development process, as enormous time and effort had to be invested in community consultations to ensure wide community acceptance of the project (Interview, July 22, 2015). Due to the elevated costs associated with reusing the power station and its industrial site, interviewees also highlighted that financial feasibility had to be ensured through increased density and profitable residential uses (Interview, July 22, 2015). Broadly, many of the barriers and challenges seen at Battersea are a result of fundamental conflicts between the three pillars of sustainability: the community, the environment and the economy. 


\section{Discussion \& Recommendations}

While the redevelopment of Austin's Seaholm Power Plant and London's Battersea Station have been undertaken in different countries, planning contexts, political climates, at different scales, and under different development models, the two projects offer many common themes and lessons learned of relevance to the Richard L. Hearn Power Generation Station in Toronto. Thus, it is the aim of this section to discuss some of the recurring themes raised by in-depth case study of Seaholm and Battersea, and to use these commonalities to form recommendations for the Hearn's impending redevelopment.

Recommendation 1: Any redevelopment of the Hearn should be done sustainably from the outset, and should include didactic elements to foster awareness of sustainability more broadly. Further, the project should aim to incorporate and balance environmental, social and economic sustainability features and performance measures.

Firstly, the importance of sustainable development is clearly shown at both Seaholm and Battersea. This is due to the presence of sustainable development paradigms in Austin and London, enforced by various layers of preexisting legislation and policy in both cities. For example, Austin and London City officials stressed that sustainable development was status quo in their municipalities, and that developers must take a sustainable approach in their projects in order to be granted planning approval. This resulted in sustainability becoming an important part of the project vision at both Seaholm and Battersea. Further, at both developments, attempts were made to not only incorporate sustainability features, but also educate about and promote the benefits of sustainability. For example, Battersea's publicly accessible sustainability plan, Positive Energy, serves both as a sustainability framework for for Battersea's transformation and a promotional document for sustainable development itself. In Austin, creators of Seaholm's EcoDistrict plan stressed that simply incorporating sustainability into the redevelopment wasn't enough to foster a broader culture of sustainability, and that any successful sustainability initiative must also include didactic elements. Thus, a plan to 
use to Seaholm's stacks to display sustainability information and metrics was also created, and space will be reserved in the power plant's ground floor for exhibitions on sustainable development. Further, the importance of front-ending sustainability plans was highlighted in both cases. While the existence of a strict regulatory environment in London was credited with ensuring project sustainability, in Austin, it was noted that the Seaholm EcoDistrict plan had little influence over development, as it was only created after MDAs had been signed and development plans approved.

Although sustainability was critical at Seaholm and Battersea, conflicts existing between the three pillars of sustainability - economic, environmental and social - were evident in both cases, as both projects put an emphasis on economic development, a trend also seen in much brownfields literature. The conflict between heritage preservation and energy efficiency was evident in both projects, while tension between economic and social sustainability was also manifest in both Austin and London through the neglect of affordable housing provisions. While in Austin this was tied to a lack of enforceable policy tools and regulations, in London, affordable housing was sacrificed to fund the massive infrastructure and transportation improvements deemed necessary to project financial viability. However, providing affordable housing is an important element of creating successful communities in large urban centres, and more of an attempt should have been made to balance the three pillars of sustainability. While the Toronto Green Standard (City of Toronto, 2015), a two-tier set of sustainability performance measures for air quality, climate change and energy efficiency, water quality and efficiency, ecology and solid waste, now mandates some environmental sustainability in all new development projects in Toronto, the program does not include social or economic sustainability goals. Thus, development at the Hearn should not only maximize environmental sustainability by striving to meet Tier-2 Green Standard performance measures (which are voluntary), but should also aim for a more holistic sustainability vision, which also includes social and economic components.

Recommendation 2: A shared vision and concerted effort between multiple levels of government, the development team, and community groups will be critical to project 
success at the Hearn. Further, planning and development flexibility will ensure resilience and innovation over extended project timelines.

Given the large-scale of development at both Battersea and Seaholm, it was also evident that a concerted effort from multiple levels of government, the community and the development team were key to project momentum. In London, interviewees suggested that political alignment between Wandsworth Council, the Greater London Authority and the Central Government was instrumental in securing funding for the Northern Line Extension, which in turn ensured the development's financial feasibility. Although Battersea's development is seen as a private endeavour, the significant funding provided by the City for the NLE does make it a partnership of sorts. Similarly in Austin, the City and the development team are explicit partners in Seaholm's transformation, as the project is a Public Private Partnership (P3). Further, both the State and City provided grants to Seaholm's tenants in order to ensure the development's occupancy and overall project viability. Public ownership and involvement in Seaholm's redevelopment has also helped ensure that the project meets key deliverables. While community members interviewed for this research project were generally dissatisfied with the 'financialization' of Seaholm and Battersea, it is evident that community interest and support were nevertheless instrumental in saving both power stations from demolition. Thus, community interest, while cited as adding considerable complexity to both projects, was pivotal in ensuring that community benefits, such as heritage preservation, were integrated into Seaholm's and Battersea's redevelopment.

The importance of development flexibility over extended project timelines was similarly raised at both Seaholm and Battersea. In Austin, a flexible Master Development Agreement (MDA) based on key outcomes rather than prescriptive terms has allowed Seaholm to maintain feasibility despite changing market conditions over its 12-year timeline. It was noted by the developer that without flexibility programmed into Seaholm's MDA, the project would have fallen through on multiple occasions. Similarly, Battersea's redevelopment will also profit from planning flexibility, as City officials have 
allowed ambiguity regarding the energy source for BPSDC's district heating network in order to accommodate changing technology over the project's decade-long construction period. This prevents the developer from being locked-in to antiquated energy production methods, and ensures that upon project completion in 2024, the most current technology is being used.

Recommendation 3: Given the broad infrastructure and transportation improvements necessary in the Port Lands, large-scale and holistic redevelopment of the Hearn's surrounding area will allow impactful sustainability measures to be implemented.

Another common theme isolated in the Battersea and Seaholm cases is the challenge of redeveloping former industrial districts into sustainable mixed-use neighbourhoods; a challenge that can be addressed through large-scale development. As both Battersea and Seaholm are located on valuable central waterfront property, but suffer the scars of decades of industrial use, significant investments had to be made to overcome industrial barriers and ensure project success. These barriers include lack of servicing (ironically, including electrical power), elevated rail lines, neighbouring active industrial properties, and a notable paucity of transportation and social infrastructure, conditions that also complicate redevelopment at the Hearn. However, at Battersea and Seaholm a districtwide approach to development combined with integrated infrastructure and multi-modal transportation plans have been used to surmount many of these industrial barriers. In London, the creation of a district heating network is only possible because of the scale of Battersea's redevelopment, and adds significantly to project innovation and sustainability. Similarly, the many infrastructure improvements that will service Battersea run through the entire VNEB area, and would have been impossible had the development taken a building-by-building approach. These improvements include the extension of the Underground into the Nine Elms area, improved cycling and pedestrian routes, extended bus service and a new waterbus in the area, a new pedestrian bridge over the Thames, parks, open spaces, a health centre and community hub. Similarly at Seaholm, integrating the development site into the surrounding city grid by extending major arterials into the area has been critical to project success. The construction of the 
Pfluger Pedestrian Bridge, the creation of various bike and pedestrian trails surrounding the site, and the possible location of a commuter rail hub near Seaholm have also contributed greatly to the site's transformation from an isolated industrial district into a successful mixed-used neighbourhood. The Hearn's proximity to the Martin Goodman Trail offers an opportunity to integrate into Toronto's largest cycling and pedestrian route, and plans for multiple bridges over the Shipping Channel outlined in the Port Lands Planning Framework Land Use Direction (City of Toronto, 2014) will also contribute significantly to overall connectivity.

Similarly, both the Seaholm and Battersea projects have progressed despite directly neighbouring active industrial sites and rail lines, as is also the case with the Hearn. Battersea's neighbour to the east is an active waste transfer station, while Seaholm lies directly west of a functioning electric substation. While careful design at Battersea will minimize impact from the Cringle Dock waste station, Seaholm will construct an 'artwall' between the development and the electric substation in order to limit negative impacts on the development. Further, there are plans to reuse the freight rail bridge that runs just west of Seaholm for a commuter rail line that will service the area. Thus, innovative thinking will allow similar industrial 'barriers' to be overcome at the Hearn.

Recommendation 4: The Hearn's industrial features and existing infrastructure should be viewed as potential resources, and should be adaptively reused to contribute to project innovation and sustainability.

Despite the substantive challenges posed by former industrial sites mentioned above, the redevelopment of Battersea and Seaholm also demonstrate that industrial features can be regarded as assets. Another common theme raised in both case studies was the adaptive reuse of industrial infrastructure for innovative sustainability purposes. For example, the Battersea redevelopment will capitalize on its proximity to two protected wharves on the Thames to transport excavated materials by barge, thus minimizing vehicular transport during construction. Further, Battersea's vast coal bunkers will also house the area's new sustainable district heating network (DHN), while two of the 
building's iconic chimneys will release vapour from the DHN. As the development team is currently investigating using the Thames as a source of energy for the DHN, via innovative surface water source heat pump (SWSHP) technology, the many pipes and tunnels that once connected Battersea Station to the river for cooling purposes, may also be reused for energy production. Similarly, at Seaholm, massive underground water tanks once used to cool the plant's boilers will be reused as water catchment cisterns for all on-site irrigation. Further, as previously mentioned, the freight rail line that runs beside Seaholm may be reused for commuter trains, thus improving sustainable transportation in the area. As Canada's largest power station, the Hearn undoubtedly contains valuable industrial features that should be explored as means of contributing to project sustainability. For example, while little information is available on the Hearn's interior structure, the rail line that runs just south of the site and the building's massive concrete foundation should be regarded as valuable project resources. Further, the site's location on the Shipping Channel could be used to make transportation of excavated and construction materials more sustainable.

Recommendation 5: The Hearn's iconic structure and unique 'brand' will be an asset to any redevelopment project, and adds tremendous value to the site. The Hearn's heritage should be preserved and activities that contribute to the building's identity should be supported until redevelopment.

Battersea and Seaholm power stations are both iconic heritage buildings that have defined their respective urban landscapes for decades. Interviewees from both redevelopment projects highlighted that the image, identity and broad public support for these two buildings saved them from demolition, even as they lay vacant and underutilized for decades after decommission. Similarly, in both developments, the strong 'brand' created by the power stations was credited with counteracting any negative perceptions or stigma associated with the former industrial districts in which they sit. Further, in cities such as London and Austin, which have seen rapid development drastically alter their skylines, the adaptive reuse of such iconic structures is seen as refreshingly 'authentic' and unique. Also key to the cultured, urban identity of 
Seaholm and Battersea is their history of cultural uses. While Seaholm was originally slated to be redeveloped into a cultural building, and hosted various arts events before redevelopment started, Battersea has served as a backdrop for British pop-culture since the 1960s, appearing widely in films, music videos and album covers. Both power stations will also maintain cultural use post-redevelopment. A portion of the Seaholm plant will be used for public art displays, and Battersea will house cultural, educational and creative office uses once redevelopment is complete. The popularity and cultural resonance of these two power stations also ensured the viability of their redevelopment projects, as both Battersea and Seaholm sold-out their residential units mere days after going to market. Building up the Hearn's cultural importance and popularity is thus undeniably important to the future success of its adaptive reuse. While there has been notable recent interest in the Toronto power station, with Luminato, the Unsound Music Festival, and Vice Canada all recently renting the building for cultural events, additional attempts should be made to solidify the Hearn's cultural significance to Toronto, thus establishing the historic building as an important part of the city's past and future.

Recommendation 6: A developer with a combination of vision, experience, access to capital and patience should oversee the Hearn's transformation.

As redevelopment projects of former industrial lands require deep resources, span extended timelines, and involve overcoming significant barriers, interviews at Seaholm and Battersea highlighted the importance of landing the right developer for each project. As Seaholm and Battersea took divergent approaches to development - Seaholm is a P3, while Battersea is an entirely private endeavour - the developer characteristics that led to project momentum and realization are understandably distinct for each project. For example, at Seaholm, the developer is local, and has a personal interest in the power station and sustainability. Further, the development team, Southwest Strategies, has made a name for themselves adaptively reusing and redeveloping industrial properties, and thus has experience and knowledge about these kinds of development projects. It was this experience, vision and personal commitment to the project, combined with substantial support from the City, that allowed the developer stay with 
the project through the 2008 recession and various market fluctuations, to see Seaholm through 12 years of development. Conversely, Battersea, as a private development project, is mainly incented by economic success, and has thus transferred ownership multiple times since it was decommissioned in the 1980s. Given the large scale of the Battersea project, and the immense financing needed for infrastructure upgrades throughout the area, project plans fell through on numerous occasions due to lack of funding. As Battersea's current developer has access to deep up-front financing from Malaysian government pension funds, interviewees linked this characteristic with project momentum this time around, and noted that getting the Battersea redevelopment off the ground required a perfect alignment of planning, market conditions and funding. No matter if the Hearn is developed privately or under a P3 model, the skills and characteristics brought forward by the developer will be instrumental to project outcomes.

Recommendation 7: Innovative value-capture tools, such as TIF, should be investigated as funding options for development-supportive infrastructure at the Hearn, and the Toronto Port Lands more broadly.

As brownfield redevelopment revitalizes formerly derelict areas, and involves major upfront costs such as environmental remediation and infrastructure/transportation improvements, this makes such projects ideal for value-capture financing tool such as Tax Increment Financing (TIF). At both Seaholm and Battersea, TIF is being used to access funding for supportive infrastructure, to be repaid via future uplift in land values associated with development. Although TIF structures vary between the US and the UK, the use of such value-capture tools to gain up-front access to funding is common between the two cases. While Tax Increment Equivalency Grants (TIEGs) do exist in Ontario, and can be given to developers to help fund brownfield development in conjunction with Community Improvement Plans (CIPs), these grants are usually used to cover site-specific ESA, remediation and environmental insurance premium costs (Ontario Ministry of Municipal affairs and Housing [MMHA], n.d.). However, municipalities themselves using TIF to access up-front funding for development- 
supportive infrastructure projects, such as public transportation, is untested terrain in Ontario. In fact, TIF-enabling legislation would have to be created by the Province before the City could use such a financing tool to catalyse development at the Hearn, and in the Port Lands more generally. If the City were allowed to use TIF to finance broad infrastructure improvements in the Port Lands, it could create a TIF Zone in the Port Lands for a specified term (typically 20 or 30 years), forecast the uplift in property taxes that would result from the area's redevelopment during this term, and then take a loan out to be repaid with this future revenue. As the Port Lands, and the Hearn site itself, currently contribute little by way of property taxes to the City, the uplift could be significant were the area intensified and redeveloped into a dense mixed-used neighbourhood, making the area ideal for land value capture funding tools such as TIF. 


\section{Appendix A: Brownfields Sustainability BMP: Information Collection Table (Created by Dr. Christopher De Sousa)}

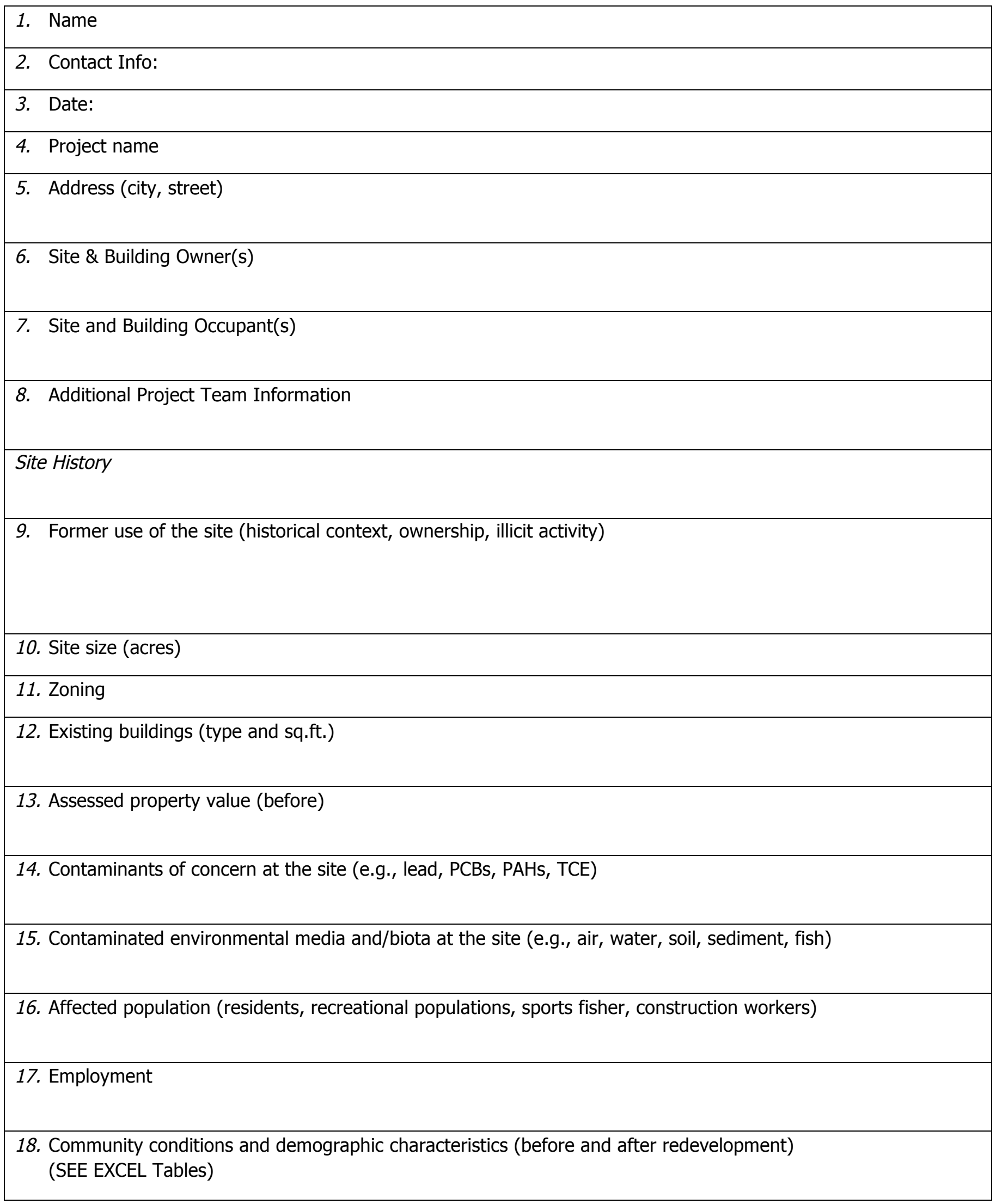


19. Why was the site selected for redevelopment?

20. Discuss how the project vision evolved?

21. What prompted the initial interest in incorporating green/sustainable elements into the project (supporters/goals/pressures)?

22. Were there any barriers or opposition to this project vision at an early stage? (discuss)

23. What proportion of local brownfield projects incorporate sustainability/green features?

Project Attributes

24. General land use \& project characteristics

a. Lot size (subdivided sizes)

b. Revised zoning(s)

c. New and refurbished buildings (type sq.ft.)

d. Assessed property value (after)

e. Employment created/retained 
25. Project Details and Process (start dates and end dates for)

\begin{tabular}{|c|c|c|c|}
\hline & Timeline & $\begin{array}{c}\text { Key } \\
\text { Stakeholders }\end{array}$ & $\begin{array}{c}\text { Process } \\
\text { (steps, challenges, tools) }\end{array}$ \\
\hline a) Visioning & & & \\
\hline b) Site acquisition & & & \\
\hline $\begin{array}{l}\text { c) Planning \& } \\
\text { design }\end{array}$ & & & \\
\hline 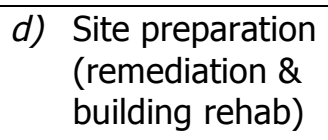 & & & \\
\hline $\begin{array}{l}\text { e) Development \& } \\
\text { Construction }\end{array}$ & & & \\
\hline f) Sale \& Lease & & & \\
\hline $\begin{array}{l}\text { g) Monitoring \& } \\
\text { maintenance. }\end{array}$ & & & \\
\hline
\end{tabular}


26. Project cost, funding sources, and financing mechanisms utilized? (public, private, nonprofit, other)(land acquisition, design, construction, operations, programming)

27. Regulatory framework for cleanup and development (state and local)

28. Public Participation 
Project Components/Issues - Environment/Green Components

Site \& Landscape (Site remediation (Innovative cleanup approach); Infrastructure (alternative transportation, water), Landscape

Building(s) Pre-existing structures and materials (e.g., building resources/waste recovery and reuse)'

Building \& design (development cost, assessed value, LEED)' Energy requirements (efficiency, conservation \& generation)' Water requirements (efficiency)

LEED (Sustainable Sites, Energy \& Atmosphere, Materials \& Resources, Indoor Environmental Quality)

a) Please describe what you are doing in this regard (**goals/features, Quantitative Benchmarks data collection; get relevant reports \& pre-development benchmarks if available).

b) Did you consider other alternatives or approaches (describe)?

c) What motivated you to select this one?

d) What roles have different stakeholders played in addressing/implementing this component/issue? (financing \& management) 
e) What obstacles have you encountered, if any?

f) What factors have enabled you to overcome these obstacles and move this component forward?

a. If a more sustainable/green approach was not taken and the issue not addressed in 19b then ask: if it was considered and, if so, why it wasn't implemented?

b. What might have encouraged you to consider a more sustainable/green approach to this component/issue? (Incentives, information, policies \& programs, etc.) 
Community \& Quality of Life - Site/Project scale (Public Health [Any reported health symptoms related to the site by community members], Affordability, Historical Preservation); Community (Community Amenities (cultural, recreational, or retail amenities), Blight removal, Public involvement

a) Please describe what you are doing in this regard (**goals/features, Quantitative Benchmarks data collection; get relevant reports \& pre-development benchmarks if available).

b) Did you consider other alternatives or approaches (describe)?

c) What motivated you to select this one?

d) What roles have different stakeholders played in addressing/implementing this component/issue? (financing \& management) 
e) What obstacles have you encountered, if any?

f) What factors have enabled you to overcome these obstacles and move this component forward?

a. If a more sustainable/green approach was not taken and the issue not addressed in 19b then ask: if it was considered and, if so, why it wasn't implemented?

b. What might have encouraged you to consider a more sustainable/green approach to this component/issue? (Incentives, information, policies \& programs, etc.) 


\section{Economic}

Site/Project scale (Employment \& job training (created/retained, conventional and green); Community (Local real estate implications; Local economic activity implications(multiplier))

a) Please describe what you are doing in this regard (**goals/features, Quantitative Benchmarks data collection; get relevant reports \& pre-development benchmarks if available).

b) Did you consider other alternatives or approaches (describe)?

c) What motivated you to select this one?

d) What roles have different stakeholders played in addressing/implementing this component/issue? (financing \& management) 
e) What obstacles have you encountered, if any?

f) What factors have enabled you to overcome these obstacles and move this component forward?

a. If a more sustainable/green approach was not taken and the issue not addressed in 19b then ask: if it was considered and, if so, why it wasn't implemented?

b. What might have encouraged you to consider a more sustainable/green approach to this component/issue? (Incentives, information, policies \& programs, etc.) 
Project Impacts and Lessons Learned

29. Overall, what have been the main obstacles you've encountered or anticipate encountering in incorporating sustainability components into the brownfield project? (Please rank the top 3 from most challenging [1])

30. Overall, what benefits (impacts) do you think have resulted or will result from redeveloping this brownfield site? (Please describe and number in order of importance)

31. Overall, what benefits (impacts) do you think have resulted or will result from incorporating sustainable elements into the redevelopment of this brownfield site? (Please describe and number in order of importance)

32. What mechanisms or suggestions do you have for promoting and facilitating sustainability in future brownfield redevelopment projects (Please describe and number in order of importance).

33. Has this project influenced the local brownfields program? If so, how? 
34. What impact has this project had on the surrounding area?

35. Has this project influenced planning or public funding requirements in any way? If so, how?

36. Do you have any other comments, suggestions for this study, or questions that you would like us to ask others involved in sustainable brownfield projects?

37. References

Thank Very Much for Participating 


\section{RYERSONUNIVERSITY}

\section{RESEARCH ETHICS BOARD}

To: Julia Smith

School of Urban and Regional Planning

Re: REB 2015-125: Adaptive Reuse of Urban Coal Plants: In-Depth Case Studies and Planning Implications for the Hearn, Toronto

Date: May 28, 2015

Dear Julia Smith,

The review of your protocol REB File REB 2015-125 is now complete. The project has been approved for a one year period. Please note that before proceeding with your project, compliance with other required University approvals/certifications, institutional requirements, or governmental authorizations may be required.

This approval may be extended after one year upon request. Please be advised that if the project is not renewed, approval will expire and no more research involving humans may take place. If this is a funded project, access to research funds may also be affected.

Please note that REB approval policies require that you adhere strictly to the protocol as last reviewed by the REB and that any modifications must be approved by the Board before they can be implemented. Adverse or unexpected events must be reported to the REB as soon as possible with an indication from the Principal Investigator as to how, in the view of the Principal Investigator, these events affect the continuation of the protocol.

Finally, if research subjects are in the care of a health facility, at a school, or other institution or community organization, it is the responsibility of the Principal Investigator to ensure that the ethical guidelines and approvals of those facilities or institutions are obtained and filed with the REB prior to the initiation of any research.

Please quote your REB file number (REB 2015-125) on future correspondence.

Congratulations and best of luck in conducting your research.

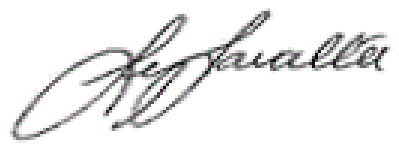

Lynn Lavallée, Ph.D.

Chair, Research Ethics Board 


\section{Bibliography}

Alberini, A., Longo, A., Tonin, S., Trombetta, F., \& Turvani, M. (2005). The role of liability, regulation and economic incentives in brownfield remediation and redevelopment:

evidence from surveys of developers. Regional Science and Urban Economics, 35(4), 327-351.

Battersea Power Station Development Company (BPSDC). (N.D.). The placemakers. Retrieved from https://www.batterseapowerstation.co.uk/\#!/go/view/app/aboutUs? view=aboutUs

Battersea Power Station Development Company (BPSDC). (2014a). Phase 3 presentation boards: Building on the approved masterplan. Retrieved from https:// bpsstorage.blob.core.windows.net/public/140415 Phase 3 Exhibition Boards.pdf

Battersea Power Station Development Company (BPSDC). (2014b). Positive Energy. Retrieved from https://bpsstorage.blob.core.windows.net/public/Positive Enegy.pdf

Battersea Power Station Development Company (BPSDC). (2014c). Powerhouse: Battersea Station Magazine, 3. Retrieved from https:// bpsstorage.blob.core.windows.net/public/ BPS Global_Launch_Powerhouse Magazine.pdf

Battersea Station Community Group (BSCG). (N.D.a). Heritage Building. http:// www.batterseapowerstation.org.uk/hist2.html

Battersea Station Community Group (BSCG). (N.D.b). History of Construction. http:// www.batterseapowerstation.org.uk/hist1.html

Bowler, C., \& Brimblecombe, P. (1991). Battersea Power Station and environmental issues 1929-1989. Atmospheric Environment. Part B. Urban Atmosphere, 25(1), 143-151.

Buchholz, J. (2015, Feb 2). First look: Austin's old power plant downtown now stunning creative office. Austin Business Journal. Retrieved from http://www.bizjournals.com/ austin/blog/real-estate/2015/02/first-look-austins-old-power-plant-downtownnow.html

Butler, K., Roy, A. \& Rosato, J. (N.D.). Rain catchment and adaptive building reuse: The historic Seaholm Power Plant. Retrieved from http://www.ctahr.hawaii.edu/hawaiirain/ Library/papers/Butler_Kent.pdf

Centre for Maximum Potential Building Systems (CMPBS). (N.D.). Seaholm stacks interactive environmental media project. Retrieved via personal communication with Brendan Wittstruck, June 20, 2015. 
Centre for Maximum Potential Building Systems (CMPBS). (2013). Seaholm EcoDistrict final report: Benchmarks + goal setting. Retrieved from https://austintexas.gov/sites/ default/files/files/Sustainability/ 130802 Seaholm_EcoDistrict_Opportunity Assessment_CMPBS.pdf

City of Austin. (2008). Seaholm redevelopment project tax increment financing reinvestment zone no. 18 preliminary project plan and reinvestment zone financing plan. Retrieved from http://www.austintexas.gov/edims/document.cfm?id=123960

City of Austin \& Seaholm Power, LLC. (2008). Master development agreement. Retrieved from https://austintexas.gov/sites/default/files/files/Redevelopment/ Redevelopment Projects/SeaholmMDA.pdf

City of Austin \& Seaholm Power, LLC. (2012). First amendment to master development agreement. Retrieved from https://austintexas.gov/sites/default/files/files/ Redevelopment/Redevelopment Projects/ First Amendment to the Seaholm MDA 20130315.pdf

City of Austin \& Seaholm Power, LLC. (2013a). Third amendment to master development agreement. Retrieved from https://austintexas.gov/sites/default/files/files/ EGRSO/Third Amendment to Seaholm MDA 09-17-2013.pdf

City of Austin \& Seaholm Power, LLC. (2013b). Declaration of restrictive covenants and reciprocal easement agreement. Retrieved from https://austintexas.gov/sites/default/ files/files/EGRSO/Declaration of Restrictive Covenants 2013062945.pdf

City of Toronto. (2013). Port Lands profile. Retrieved from http:// www.portlandsconsultation.ca/sites/all/themes/portlands/files/Port\%20Profile \%20nov12.pdf

City of Toronto. (2014). Port Lands planning framework: Land use direction. Retrieved from http://www.toronto.ca/legdocs/mmis/2014/pg/bgrd/backgroundfile-70270.pdf

City of Toronto. (2015). Toronto Green Standard for new mid to high-rise residential and all non-residential development. Version 2.0. Retrieved from http://www1.toronto.ca/City \%200f\%20Toronto/City\%20Planning/Developing\%20Toronto/Files/pdf/TGS/ TGS MidHiRise Standard.pdf

Coppola, S. (2012, June 7). Council OKs offices at iconic Seaholm plant. Statesman. Retrieved from http://www.statesman.com/news/news/local/council-oks-offices-at-iconicseaholm-plant-1/nRpK3/

Davis, M. E. (2006). Memory of the future - adaptive reuse of the Seaholm Power Plant, Austin, Texas (Masters thesis). University of Maryland, College Park. 
De Sousa, C. (2000). Brownfield redevelopment versus greenfield development: A private sector perspective on the costs and risks associated with brownfield redevelopment in the Greater Toronto Area. Journal of Environmental Planning and Management, 43(6), 831-853.

De Sousa, C. (2002). Brownfield redevelopment in Toronto: an examination of past trends and future prospects. Land Use Policy, 19(4), 297-309.

De Sousa, C. (2005). Policy performance and brownfield redevelopment in Milwaukee, Wisconsin. Professional Geographer 57(2), 312-27.

De Sousa, C. (2006). Urban brownfields redevelopment in Canada: The role of local government. The Canadian Geographer/Le Géographe Canadien, 50(3), 392-407.

Dennison, E. (2012). Battersea/Nine Elms. Architectural Design, 82(1), 82-85.

Dixon, T. (2006). Integrating sustainability into brownfield regeneration: Rhetoric or reality?-An analysis of the UK development industry. Journal of Property Research, 23(3), 237-267.

Dixon, T. (2007). The property development industry and sustainable urban brownfield regeneration in England: an analysis of case studies in Thames Gateway and Greater Manchester. Urban Studies, 44(12), 2379-2400.

EcoDistricts. (2012). Austin, Texas team snapshot. Retrieved from http://ecodistricts.org/ wp-content/uploads/2013/05/resourceguide austin.pdf

Farris, J. T. (2001). The barriers to using urban infill development to achieve smart growth. Housing Policy Debate, 12(1), 1-30.

Friends of Seaholm. (N.D.a). The Seaholm complex. Retrieved from http:// friendsofseaholm.com/Pages/building.html

Friends of Seaholm. (N.D.b). The Seaholm district master plan. Retrieved from http:// friendsofseaholm.com/pages/masterplan.html

Garner, K. (2008). Battersea Power Station: An account of the proposed demolition and rebuilding of the chimneys. Journal of Architectural Conservation, 14(2), 15-31.

Greater London Authority (GLA). (2009a). Vauxhall Nine Elms Battersea Opportunity Area planning framework sustainability appraisal draft. Retrieved from https:// www.london.gov.uk/sites/default/files/VNEB\%20Sustainability\%20Appraisal.pdf

Greater London Authority (GLA). (2009b). Vauxhall Nine Elms Battersea Opportunity Area planning framework technical appendices. Retrieved from http:// 
static.london.gov.uk/mayor/planning/oapf-nine-elms/docs/oapf-nine-elms-frameworkdraft-nov-09-appendices.pdf

Greater London Authority (GLA). (2012). Vauxhall Nine Elms Battersea Opportunity Area planning framework. Retrieved from https://www.london.gov.uk/sites/default/files/ VNEB OAPF 2012 0.pdf

Greenberg, M., Lowrie, K., Mayer, H., Miller, K. T., \& Solitare, L. (2001). Brownfield redevelopment as a smart growth option in the United States. Environmentalist, 21(2), 129-143.

Gross, D. (2014, August 7). How Ontario is winning the war on coal (according to an American). National Post. Retrieved from http://news.nationalpost.com/news/canada/ how-ontario-is-winning-the-war-on-coal-according-to-an-american Heathorn, S. (2013). Aesthetic politics and heritage nostalgia: Electrical generating superstations in the London cityscape since 1927. The London Journal, 38(2), 125-150.

Hansen, B. (2005). Renovation: Battersea Power Station to become commercial, social center. Civil Engineering-ASCE, 75(5), 23-24.

Howland, M. (2007). Employment effects of brownfield redevelopment: What do we know from the literature? Journal of Planning Literature, 22(2), 91-107.

Jackson, N. (1984). The Battersea Power Station: Use and reuse. Oz, 6, 10-14.

Kaspar, M. A. (2013). Preserving Seaholm's power. Seaholm Power, LLC. Retrieved from http://www.seaholm.info/longhistory.html

Koefoed, E. (2011). Battersea Power Station: A disturbing post-industrial landscape (Masters thesis). University College, London.

Kollewe, J. \& Osborne, H. (2014, November 28). Battersea Power Station home prices defying all logic. The Guardian. Retrieved from http://www.theguardian.com/business/ 2014/nov/28/battersea-power-station-home-prices-defying--logic

Kuitenbrouwer, P. (2010, June 22). Sports complex plan unveiled for mothballed Hearn station. The National Post. Retrieved from http://news.nationalpost.com/toronto/sportscomplex-plan-unveiled-for-mothballed-hearn-station

Lange, D., \& McNeil, S. (2004). Clean it and they will come? Defining successful brownfield development. Journal of urban planning and development, 130(2), 101-108.

Lu, V. (2013, March 26). Hearn generating station gets new development plans. Toronto Star. Retrieved from http://www.thestar.com/business/2013/03/26/ hearn generating station gets new development plans.html 
Lu, V. (2014, July 7). Hopes Emerge for refurbishing old Hearn power plant. Toronto Star. Retrieved from http://www.thestar.com/business/2014/07/07/ hopes emerge for refurbishing_old hearn_power_plant.html

Martin, J. (2014). A journey through the memoirs of a city: The transformation of Toronto's post-industrial landscape into a "memory landscape" (Masters thesis). Carleton University, Ottawa.

McCrady, P. (2013, June). Transformation of Seaholm Power Plant begins. Community Impact Newspaper, 5(8), 29. Retrieved from http://archive.impactnews.com/pdfs/CTA/ issues/CTA-2013-06.pdf

Meltzer, E. D. (2011). Adaptive reuse of the Seaholm Power Plant: Uniting historic preservation and sustainable practices (Masters thesis). University of Maryland, College Park.

Mukhopadhyay, A. K. (1975). The politics of London water. The London Journal, 1(2), 207-226.

Neuman, W. (2011). Social research methods: Qualitative and quantitative approaches (7th ed.). Boston, MA: Pearson.

Nijkamp, P., Rodenburg, C. A., \& Wagtendonk, A. J. (2002). Success factors for sustainable urban brownfield development: A comparative case study approach to polluted sites. Ecological Economics, 40(2), 235-252.

Nine Elms Vauxhall Partnership. (N.D.) The partnership. Retrieved from http:// www.nineelmslondon.com/partners

Novak, S. (2014, Feb 6). Athenahealth signs lease for Seaholm space. Statesman. Retrieved from http://www.statesman.com/news/business/athenahealth-signs-lease-forseaholm-space/ndFzp/

Ontario Ministry of Municipal Affairs and Housing (MMAH). (N.D.). Municipal financial incentives for brownfield redevelopment: Trends among Ontario municipalities. Retrieved from http://www.mah.gov.on.ca/AssetFactory.aspx?did=9590

Paull, E. (2008). The environmental and economic impacts of brownfields redevelopment. Working draft for distribution. Northeast-Midwest Institute. Retrieved from http://www.nemw.org/wp-content/uploads/2015/06/2008-Environ-Econ-ImpactsBrownfield-Redev.pdf

Pincent Masons. (2012, Feb 13). Nine Elms enterprise zone to be set up to finance Northern Line Extension. Retrieved from http://www.out-law.com/en/articles/2012/ february/nine-elms-enterprise-zone-to-be-set-up-to-finance-northern-line-extension-/ 
Porter, C. (2014). Northern Line extension to Battersea: Infrastructure investment to enable development and land use change. In European Transport Conference, 2014.

Raff, Z., Schraeder, J., O’Donnell, D., McMurray, M., Winston, W., \& Olp, K. (2012). Expanding beyond coal. Sierra Club. Retrieved from http://content.sierraclub.org/coal/ sites/content.sierraclub.org.coal/files/Expanding\%20Beyond\%20Coal.pdf

Ramsey, R. (2015). Opportunity at the Hearn. Unpublished draft report for the Toronto Port Lands Company. Retrieved via personal communication with Rebecca Ramsey, April 1, 2015.

Real Estate Opportunities (REO). (2009). Outline planning application Battersea Power Station environmental statement non-technical summary. Retrieved from https:// www.iema.net/system/files/battersea20power20station20nts20july20200920urs 0.pdf

Seaholm Power, LLC (SPLLC). (2013a). Fast facts. Retrieved from http:// www.seaholm.info/fastfacts.html

Seaholm Power, LLC (SPLLC). (2013b). Project vision. Retrieved from http:// www.seaholm.info/vision.html

Seaholm Power, LLC (SPLLC). (2013c). Timeline. Retrieved from http:// www.seaholm.info/timeline.html

Sell, S. (2014, December 7). Case study: Using Tax Increment Financing to fund the Northern Line Extension. Retrieved from http://www.placemakingresource.com/article/ 1325425/case-study-using-tax-increment-financing-fund-northern-line-extension

Staple, G., \& Slavin, M. (2012). Repurposed coal plant sites empower and revive communities. The Public Manager, 45-47.

Texas Commission on Environmental Quality (TCEQ) \& Environmental Protection Agency (EPA). (2006). Re: Ready for reuse application Seaholm Power Plant. Retrieved from http://www.epa.gov/region6/ready4reuse/seaholm rdr.pdf

Tibby, M., McDougall, W., \& Porter, C. (2010). Developing an integrated transport strategy to meet the challenges of sustainable redevelopment for an iconic Central London regeneration area. In European Transport Conference, 2010.

Transport for London (TfL). (2014). Northern Line Extension to Battersea gets goahead. Retrieved from https://tfl.gov.uk/info-for/media/press-releases/2014/november/ northern-line-extension-to-battersea-gets-go-ahead 
Under Armour. (2015, March 11). Under Armour opens first digital headquarters in Austin's revitalized Seaholm Power Plant District. Retrieved from http:// investor.underarmour.com/releasedetail.cfm?ReleaselD=901074

United States Environmental Protection Agency (EPA). (2015). The EPA brownfields program produces widespread environmental and economic benefits. Retrieved from http://www.epa.gov/brownfields/overview/OBLR Brownfield\%20postcard \%202014 v4 web.pdf

Wernstedt, K., Meyer, P. B., Alberini, A., \& Heberle, L. (2006). Incentives for private residential brownfields development in US urban areas. Journal of Environmental Planning and Management, 49(1), 101-119.

Wiens, M. (2014, July 8). What should Toronto do with the Hearn Power Generating Station? CBC News. Retrieved from http://www.cbc.ca/news/canada/toronto/whatshould-toronto-do-with-the-hearn-power-generating-station-1.2700010

Ye, L., Mandpe, S., \& Meyer, P. B. (2005). What is "smart growth?"-really? Journal of Planning Literature, 19(3), 301-315. 